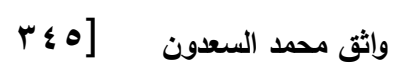

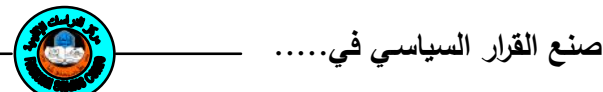

صنع القرار السياسي في سلطنة عُمان

واثثق محمد السعدون

قسم الدراسات السياسية والإستراتيجية/ مركز الدراسات الإقليمية/ جامعة الموصل

مستخلص البحث

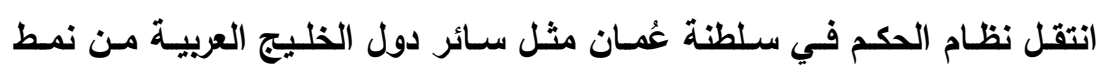

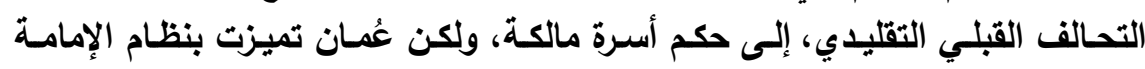

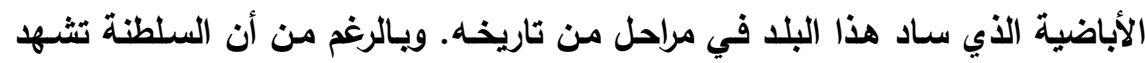

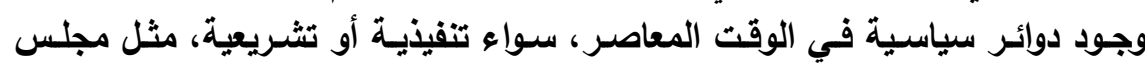

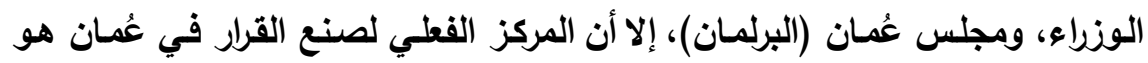

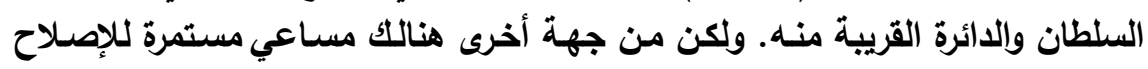

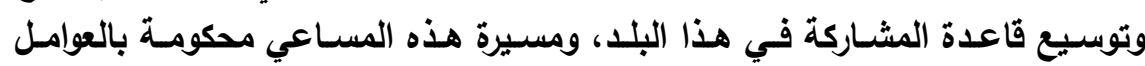
الاخلية والخارجية المؤثرة في صنع القرار العُماني.

المقدمة

تشكل الحيـاة السياسية في دول مجلس التعـاون الخليجي، ظـاهرة تثير

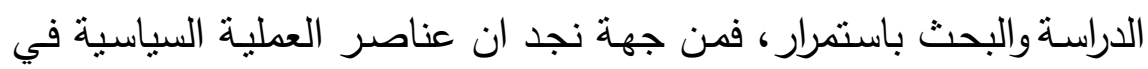

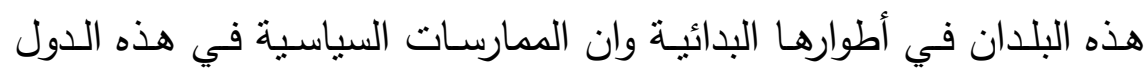

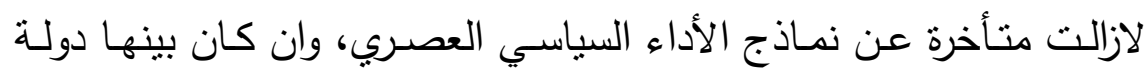
ذات إرث سياسي وحضاري مثل سلطنة عُمان. ولكننا في ذات الوقت نجد أند ان هذه الدول قد تمكنت من مواجهة واجتياز تحديات سياسية صسبة على على دلى المستوبين الخارجي والداخلي. ان تأثير قوة اقتصاديات هذه الدول في إسناد

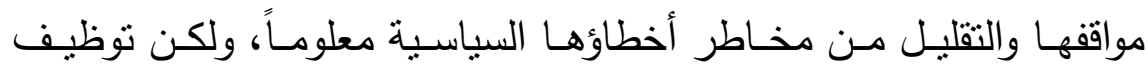

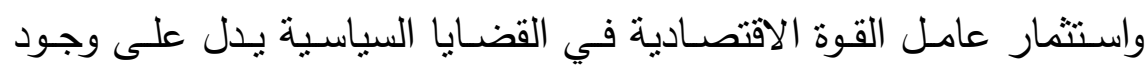


عمليـة لصنّع القرارات في هذه الدول، بغض النظر عن مسـتوى هياكلها وطبيعة أداؤها.

يهدف البحث إلى تسليط الضوء على عملية صنع القرار السياسي في

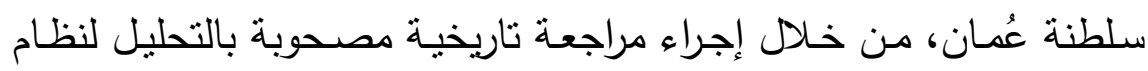
الحكم ودوائر صنع القرار والعوامل المؤثرة في صنع القرار في هذا البلد.

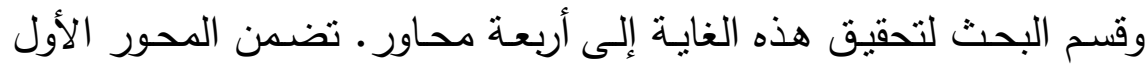

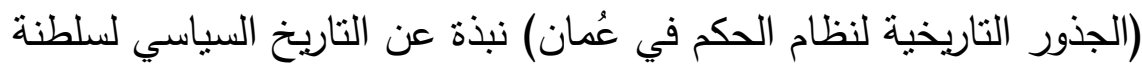
عُمان. وبين المحور الثاني (دوائر صنع القرار السياسي في عُمـان) المراكز

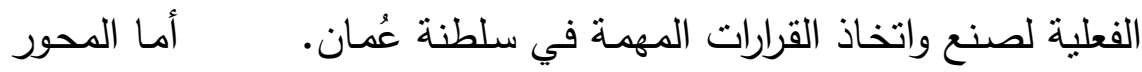

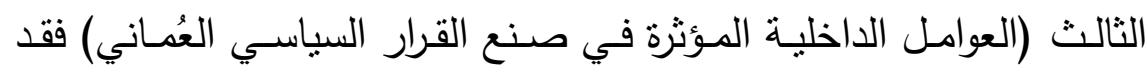
تتاول أهم التحديات السياسية والاجتماعية والاقتصادية التي تلقي بظلادلها

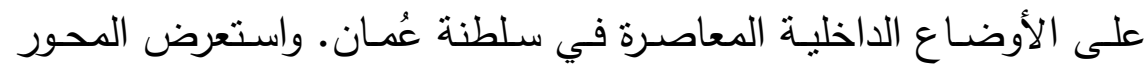

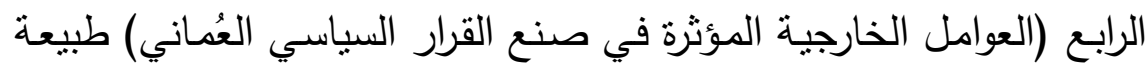
علاقات عَمان الخليجية والإقليمية والدولية وأثرها في القرار العُماني، وبيان الخيان

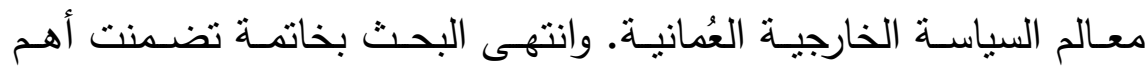
الاستتناجات التي تم التوصل إليها.

ا - الجذور التاريخية لنظام الحكم في عُمان لبحث آلية صنع القرار السياسي في بلد ما ومناقشتها، من المهم جداً أن

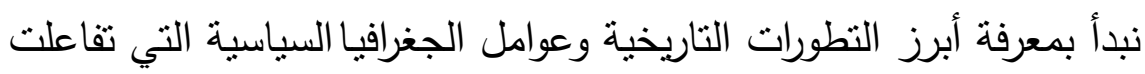

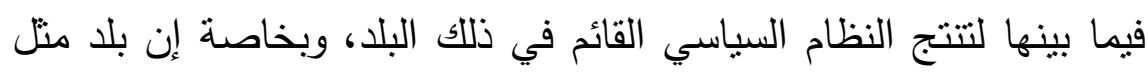
عُمان يمنلك إرثاً غنياً من مراحل النفوذ السياسي والعسكري في تاريخ

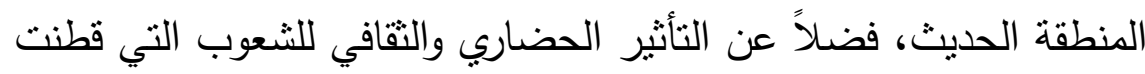
أراضي هذا البلد. فقد أثنارت الكثير من الأبحاث التاريخية إلى استيطان عدد من قبائل العرب البائدة في المناطق التي تقع ضمن حدود سلطنة 


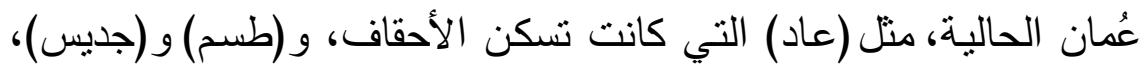

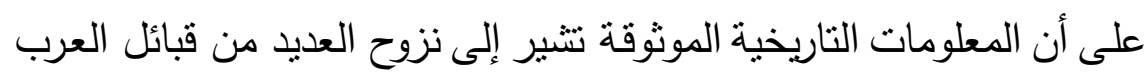

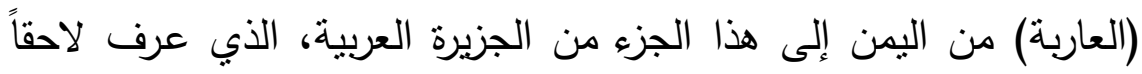

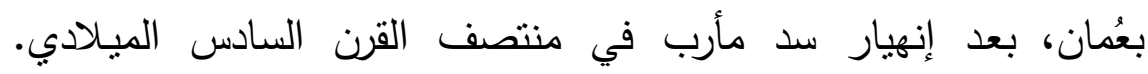

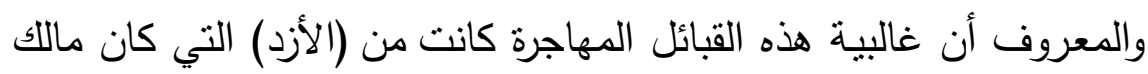

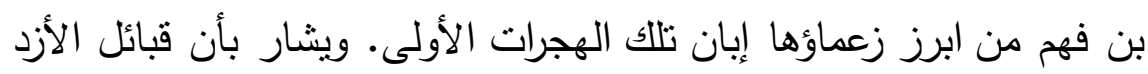

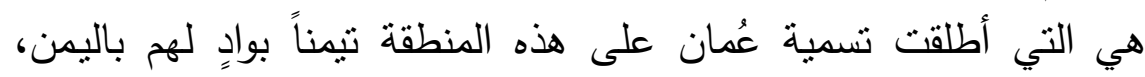

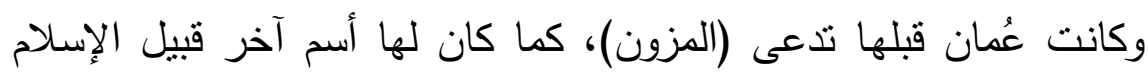

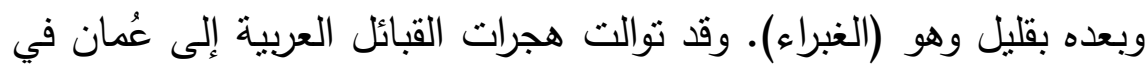

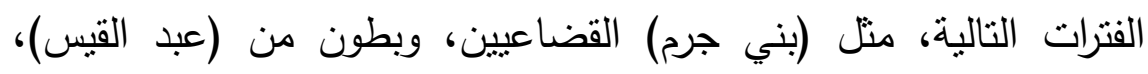

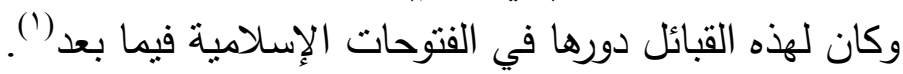

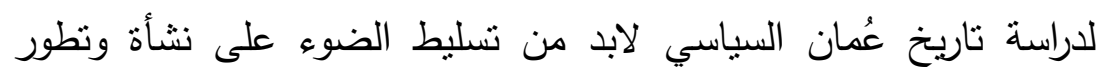

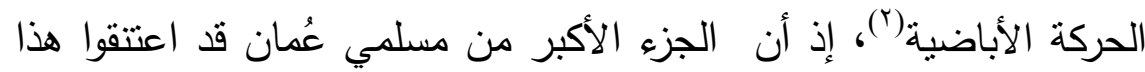

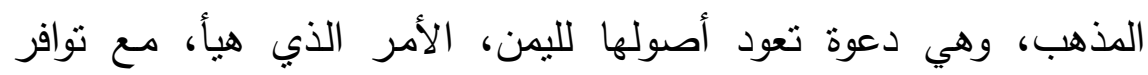

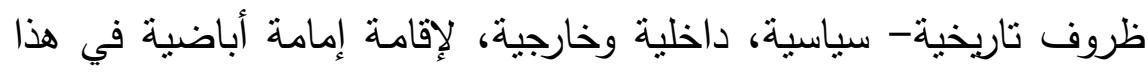

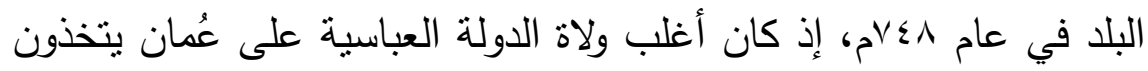

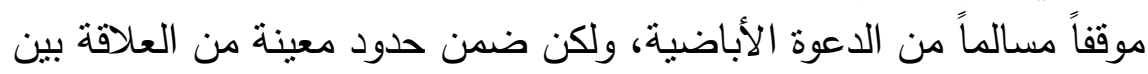

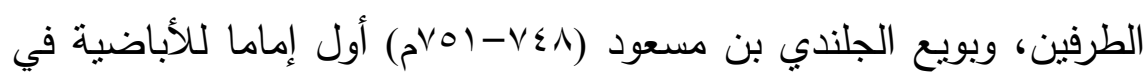

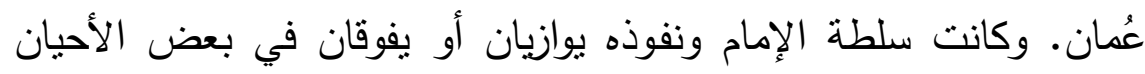

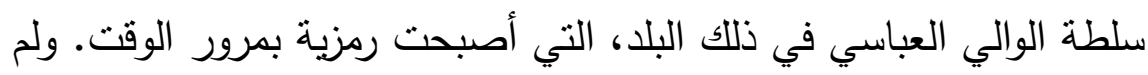

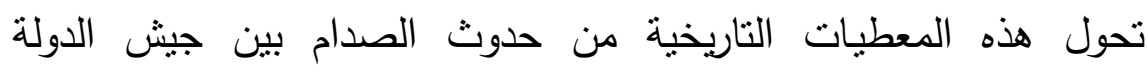

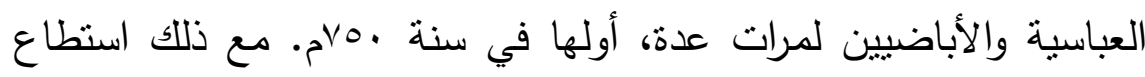

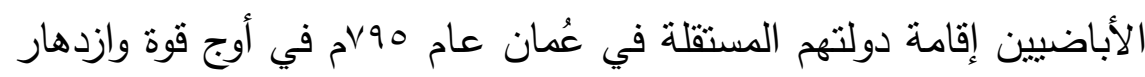

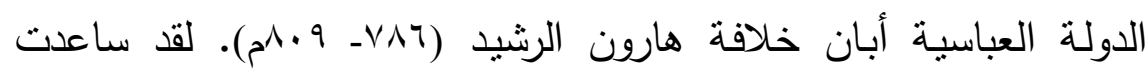

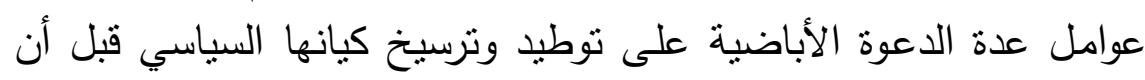


يتمكن العباسيون من مهاجمتها، منها بعد عُمان عن مركز الخلافة ببغداد،

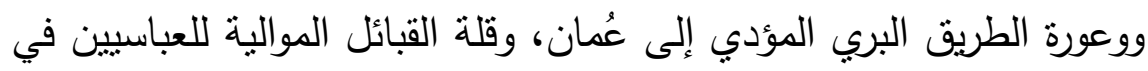

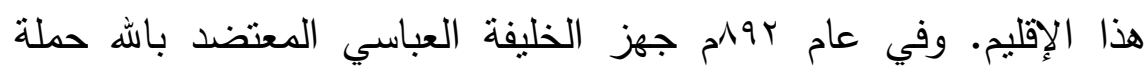

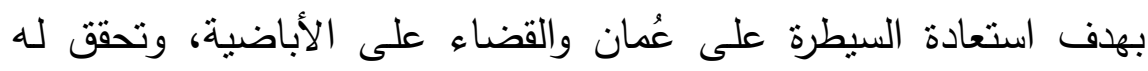

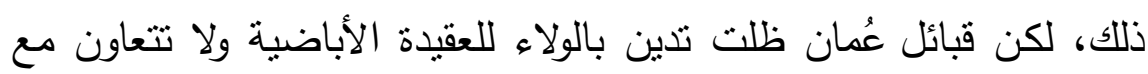

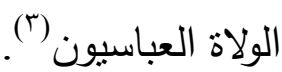

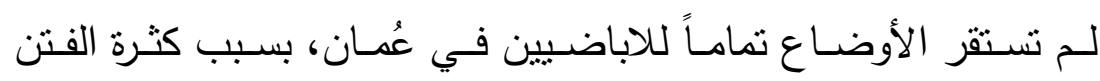

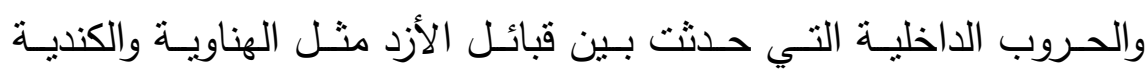

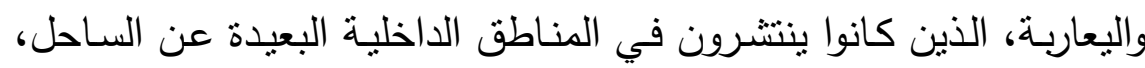

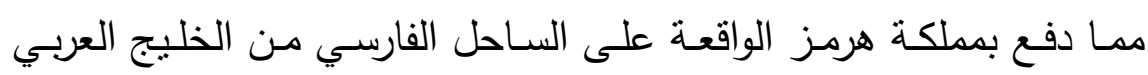

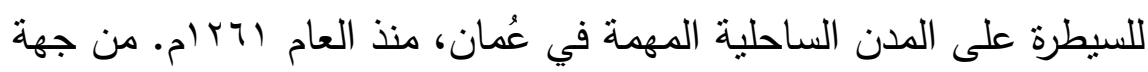

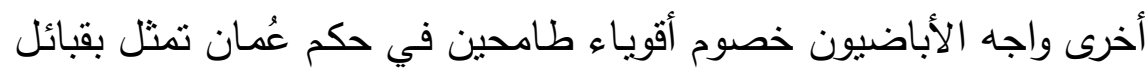

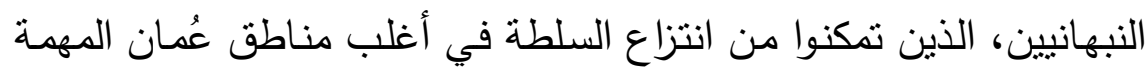

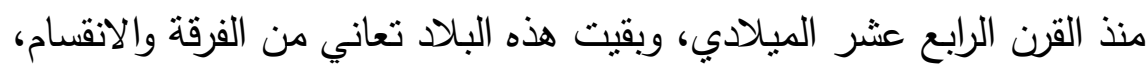

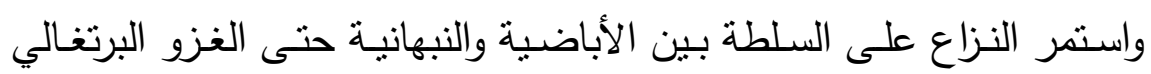

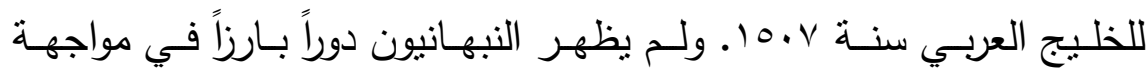

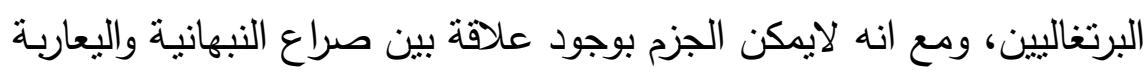

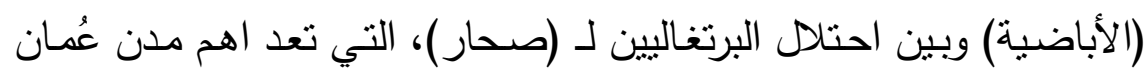

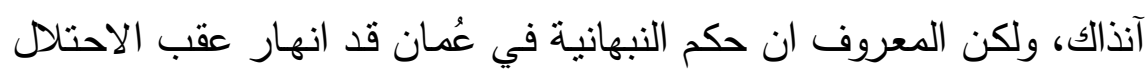

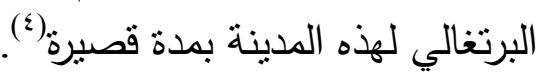

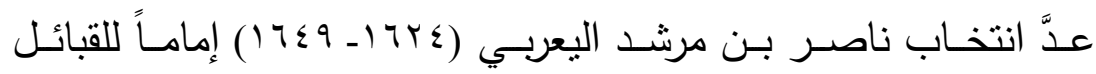

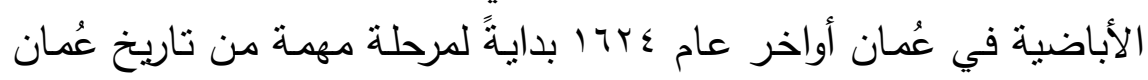

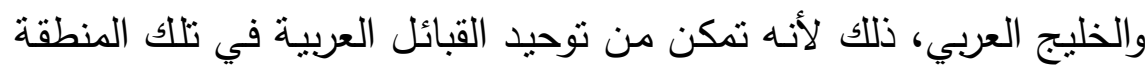

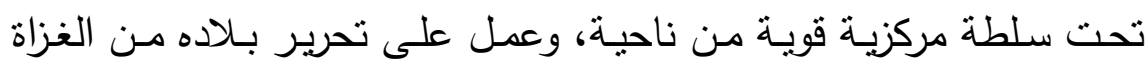

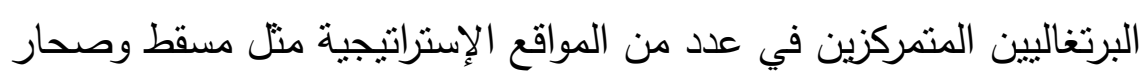


من ناحية أخرى. وقد استمرت مقاومة اليعاربة للبرتغاليين حتى تمكنوا من الخدائ

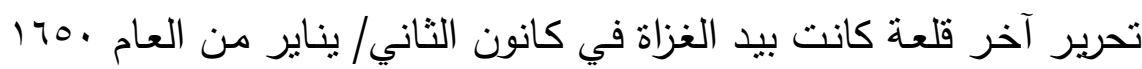

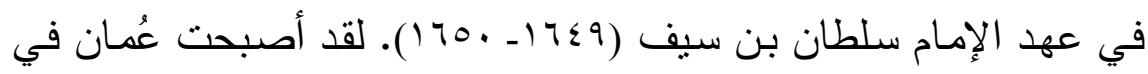

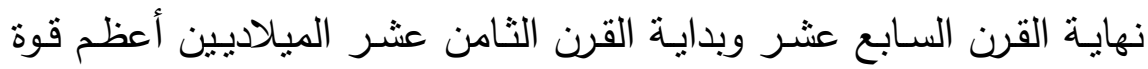

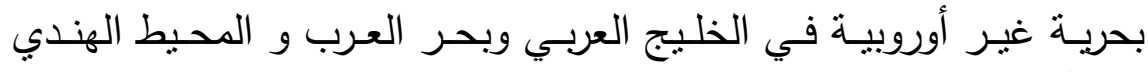

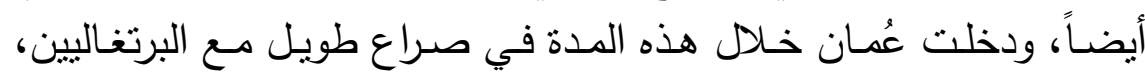
عدوهم اللدود آنذالك، واستطاعوا انتزاع الكثير من المواقع المهمة التي كانت

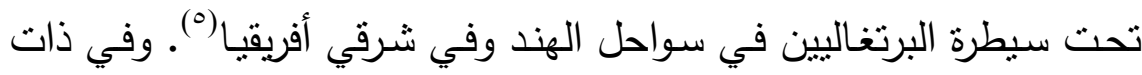

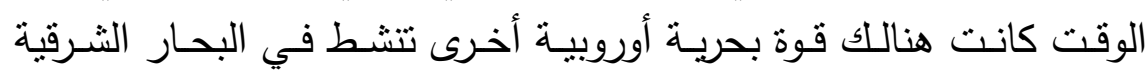

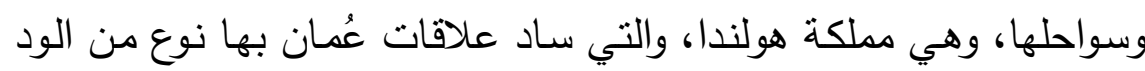

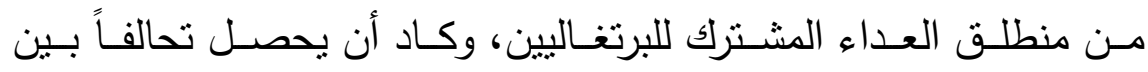

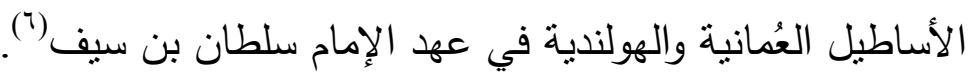

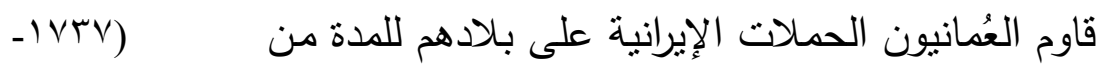

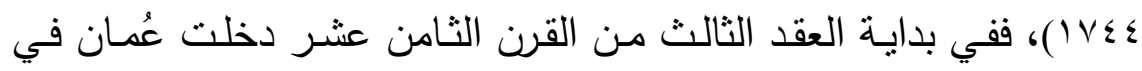

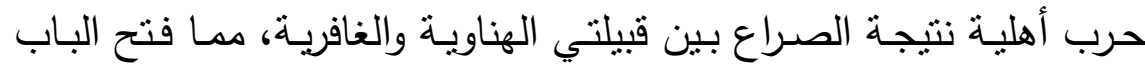

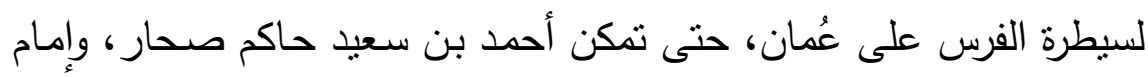

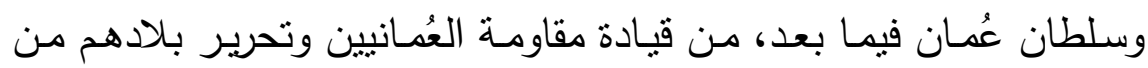

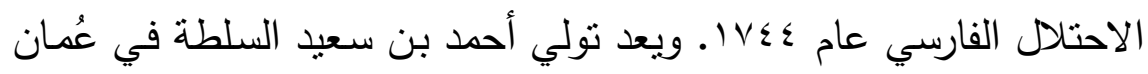

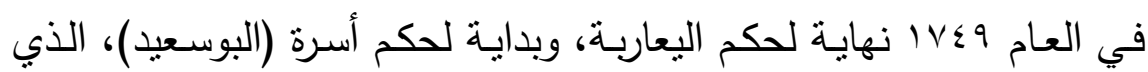

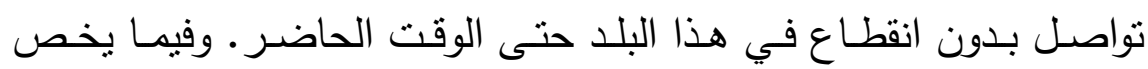

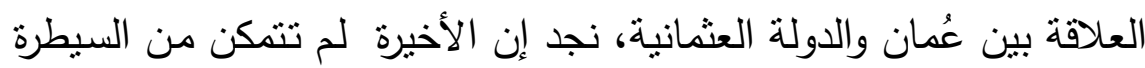

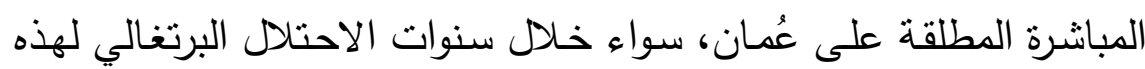

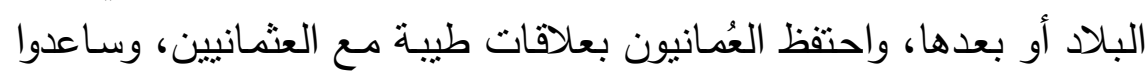

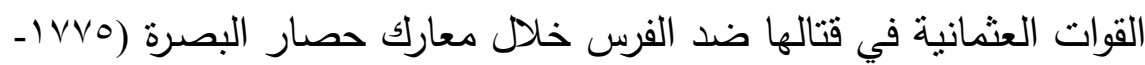


أما بالنسبة لعلاقات عُمان مع القوى العالمية الأخرى، خاصة بريطانيا

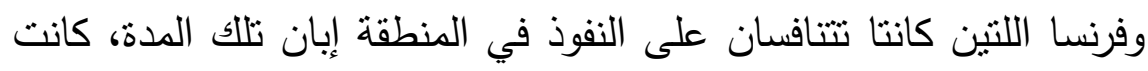

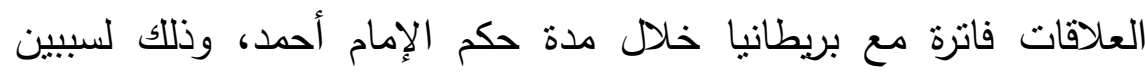

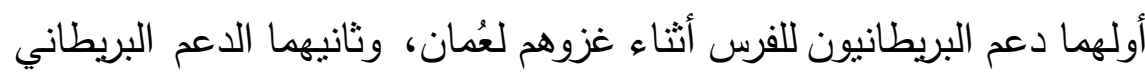

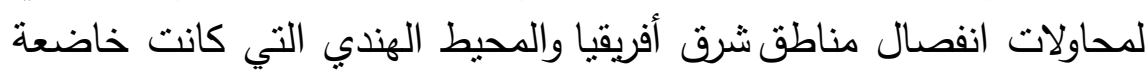

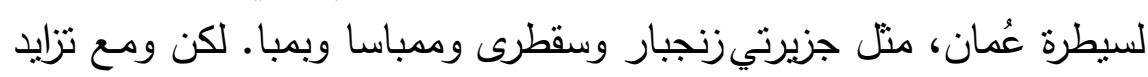

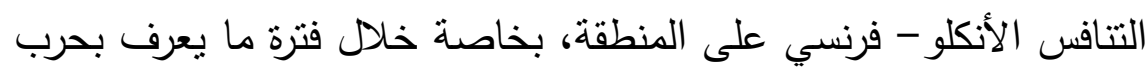

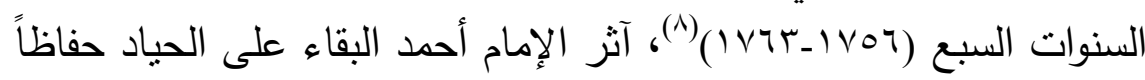

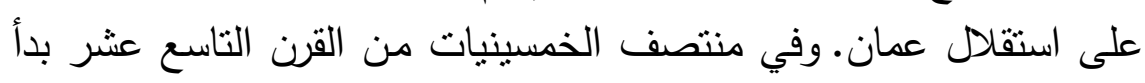

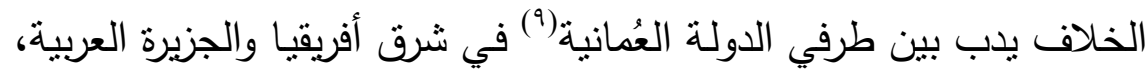

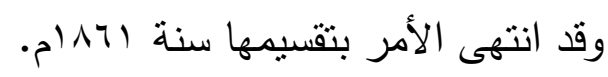

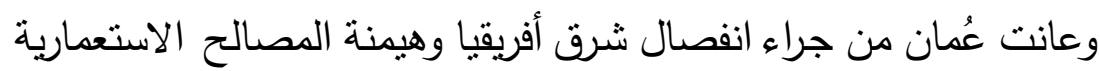

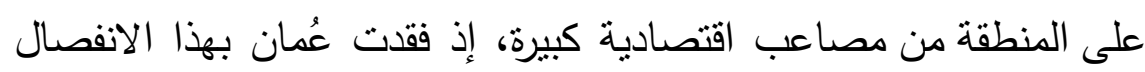

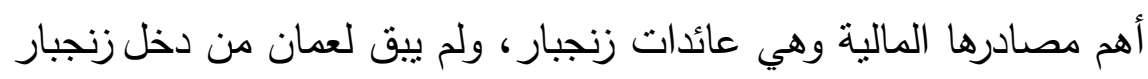

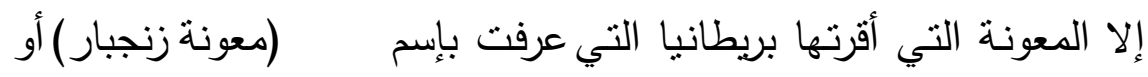

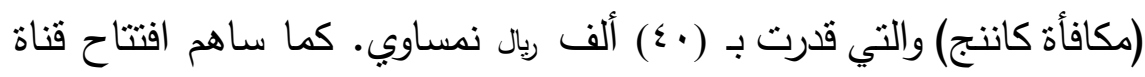

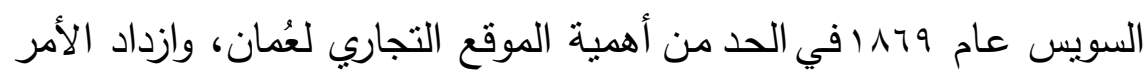

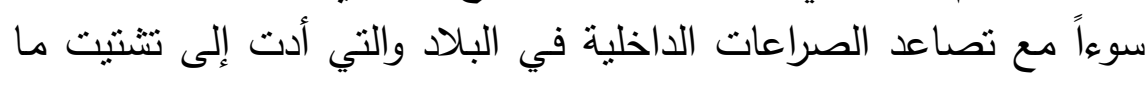

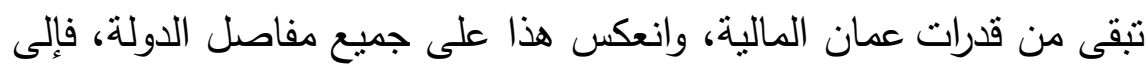

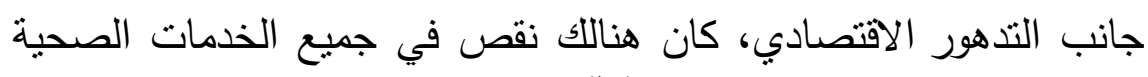

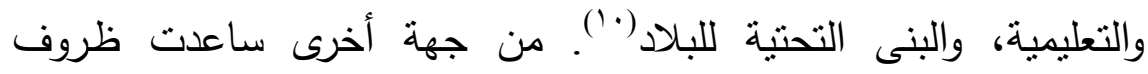

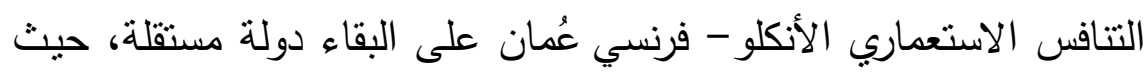

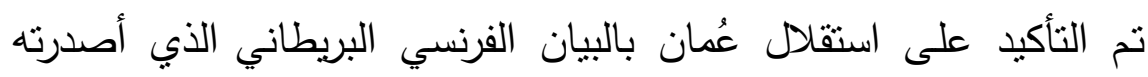

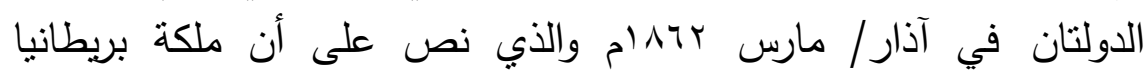

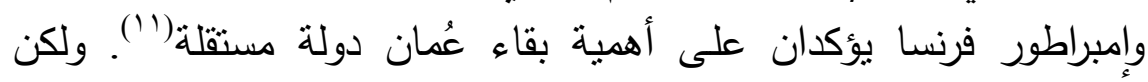


العلاقات العُمانية- البريطانية تطورت إلى مرحلة متقدمة جداً من التعاون

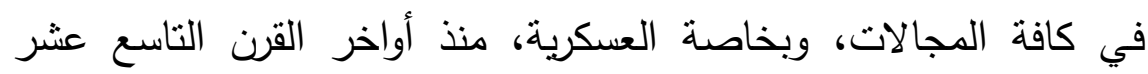

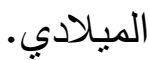

صارت هذه البلاد تعرف بـ "سلطنة مسقط وعُمان" بعد نقل عاصمتها من

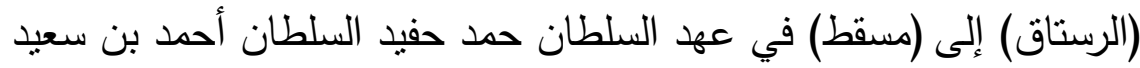

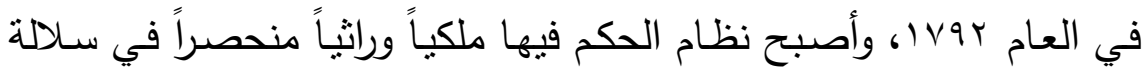

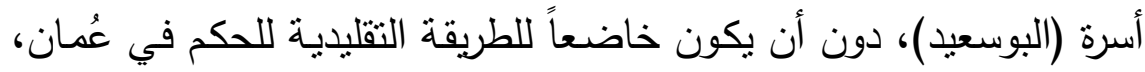

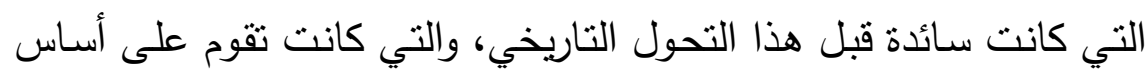

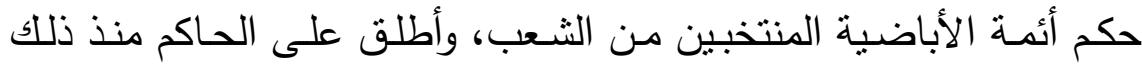

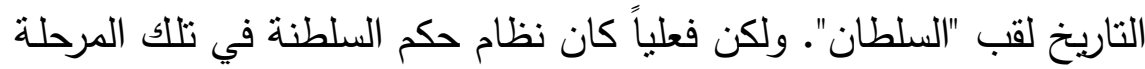

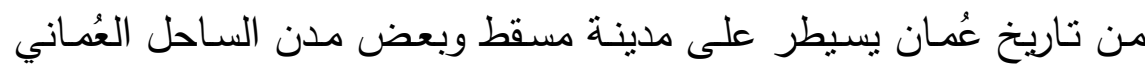

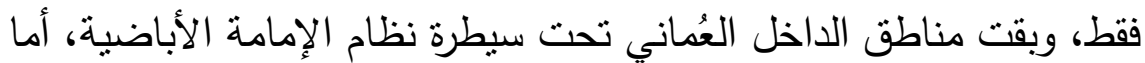

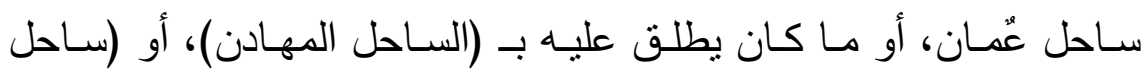

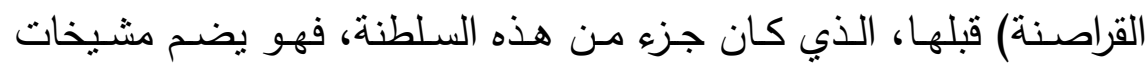

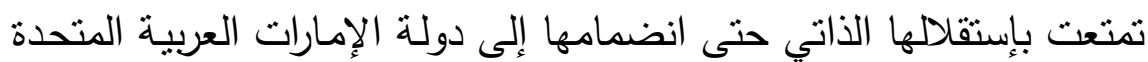

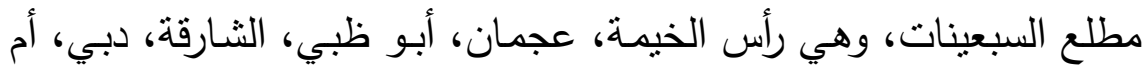

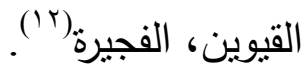

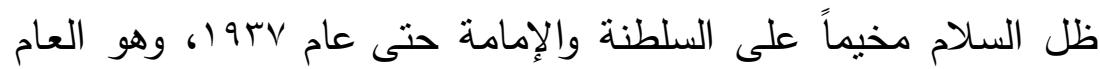

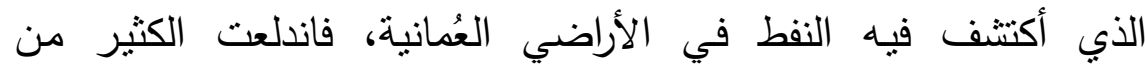
المواجهات المسلحة والحروب الأهلية بين الخصوم العُمانيون، بفعل عوامل

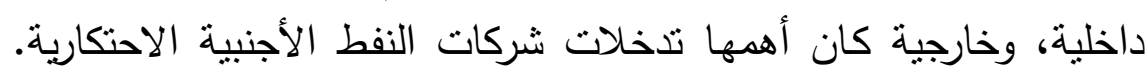

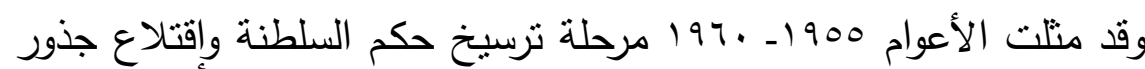

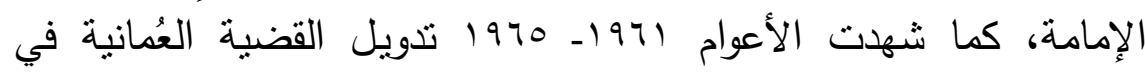

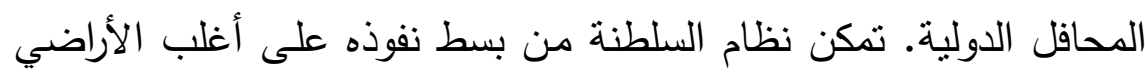

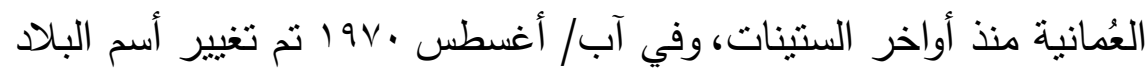


إلى سلطنة عُمان("1). واجه نظام السلطنة خلا السنوات (1970 (19v0) تحدياً خطيراً تمثل بالحرب الأهلية التي اندلعت أثز التمان التمرد المسلح الذي فلي

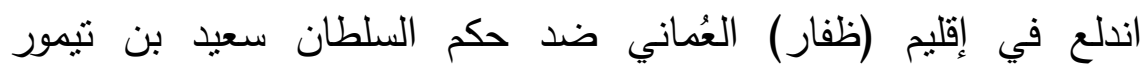

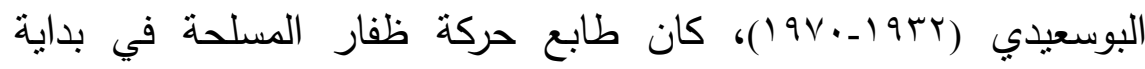
انطلاقها مزيج بين القومي العربي والإسلامي، ثم تحول إلى المنهج الماركسي الثيوعي بتأثير الحزب الثيوعي في اليمن الجنوبي عندما بدأت

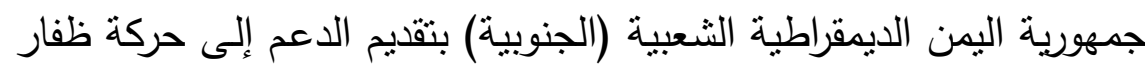
التي أطلقت على نفسها (الجبهة الوطنية الديمقراطية لتحرير عمان والخليج

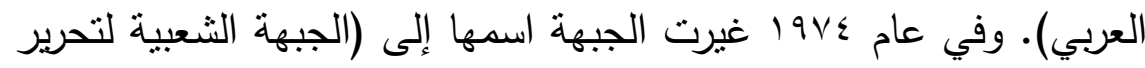

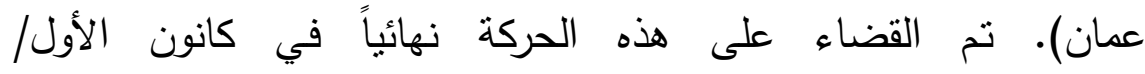

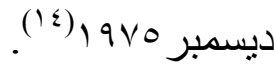

r- دوائر صنع القرار السياسي في عُمان انتقل نظام الحكم في سلطنة عُمان منل سائر دول الخليج العربية من نمط التحالف القبلي التقليدي، الذي يكون فيه الثيخ هو الأول بين متساوين، إلى حكم أسرة مالكة يقوم على الغلبة، مع بقاء شيء من شكل التحالفات

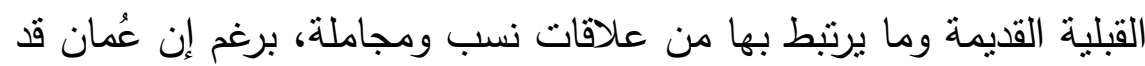
انفردت ضمن هذا الإطار العام لتحول أنظمة الحكم عن باقي دول الخليج العربية بنظام الإمامة الأباضية الذي ساد هذا البلد في مراحل من تاريخه،

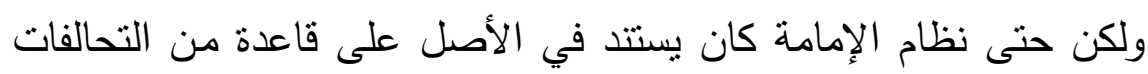
القبلية. وتعزز هذا التحول بالمعاهدات التي أبرمتها بريطانيا مع سلاطين

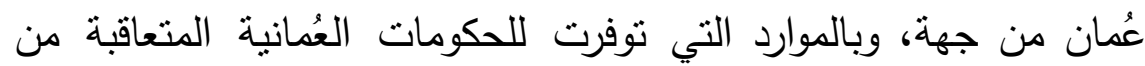

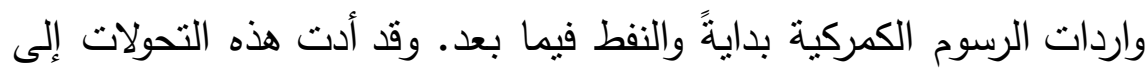

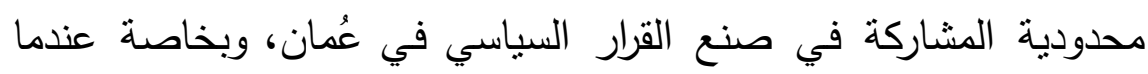
ضعف مركز القبائل والعائلات المؤثرة في المجتمع العُماني لصالح تنامي ولئي 
قوة مركز السلطان والأسرة الحاكمة. بالرغم من أن عُمان قد شهدت ثأسيس

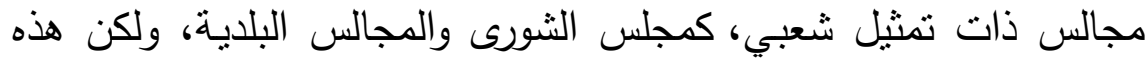
التجارب لم تسجل مشاركة فعالة لهذه المجالس في الحياة السياسية في سلطنة عُمان (10).

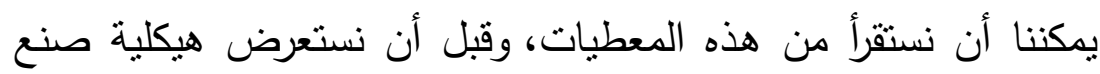

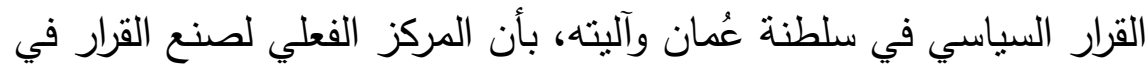

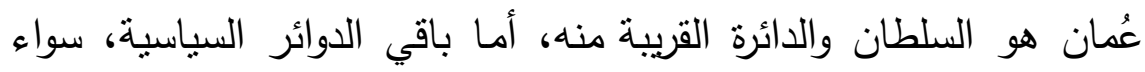

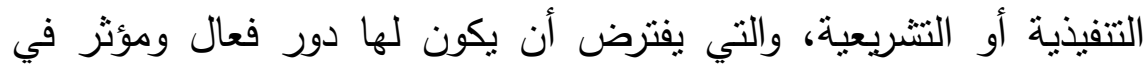
صناعة القرار، مثل مجلس الوزراء، ومجلس عُمان (البرلمان)، فأن دورها

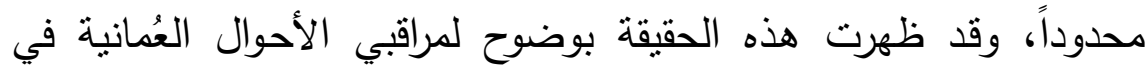

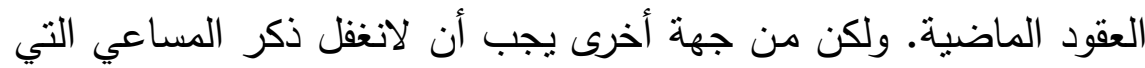

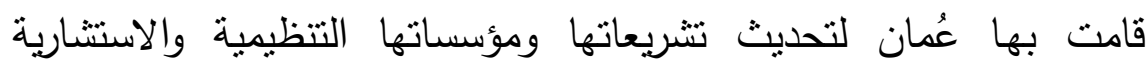

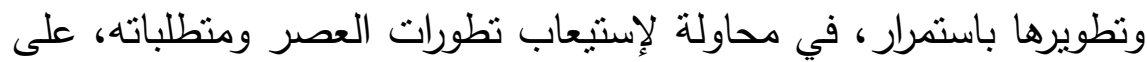
الرغم من عدم الإستقرار الإقليمي طوال المدة الماضية.

$$
\text { أ- السلطان }
$$

ظل نظام الإدارة والحكم في عُمان يعتمد على المركزية المطلقة منذ

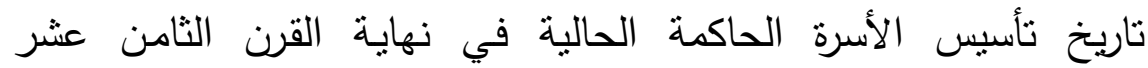
الميلادي. وقد كان السلطان حاكم مطلق، يباشر بنفسه السلطات التهات النتريعية

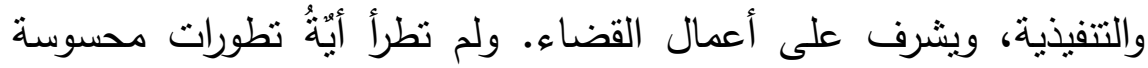

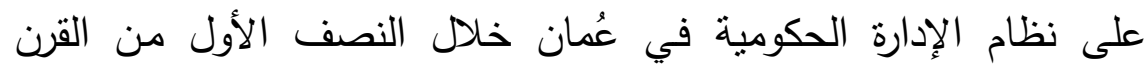

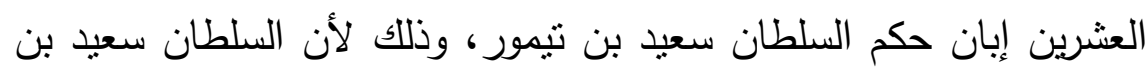
تيمور كان يصر على تسيير شؤون الحكم في بلاده بطريقة مركزية مطلقة،

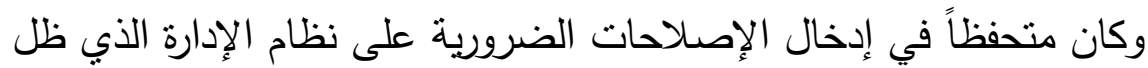

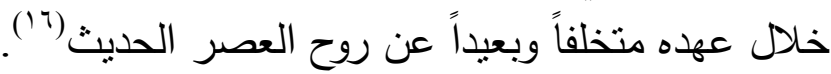


يرى الباحثون المهتمون بالثنأن العُعاني بأن بداية التطورات الجديدة في

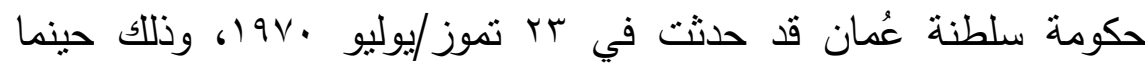

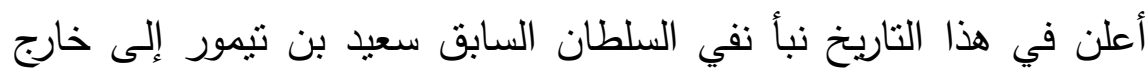

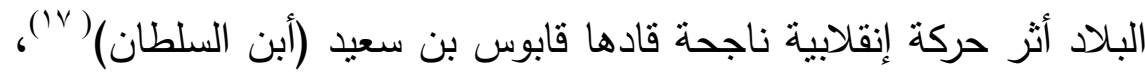

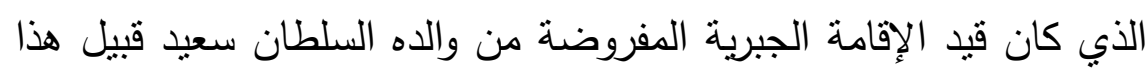

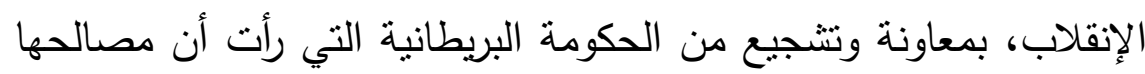

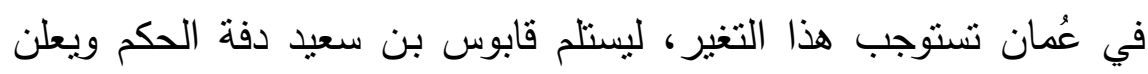

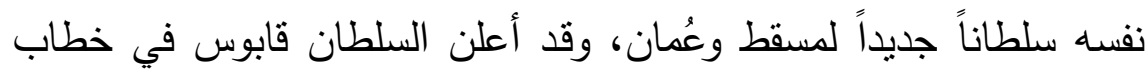

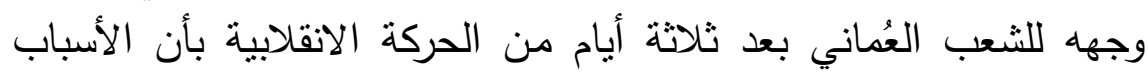

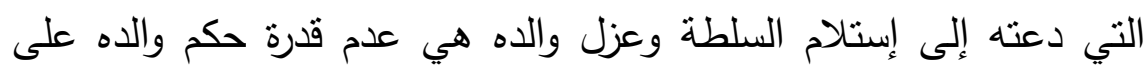

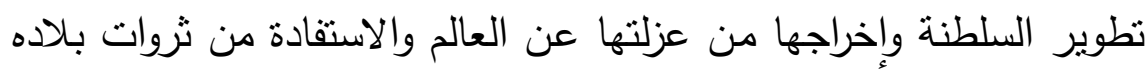

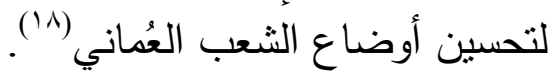

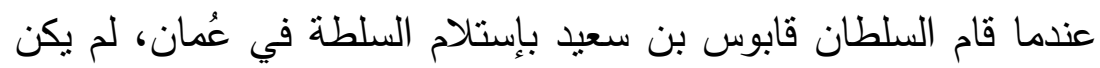

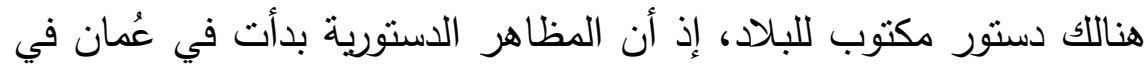

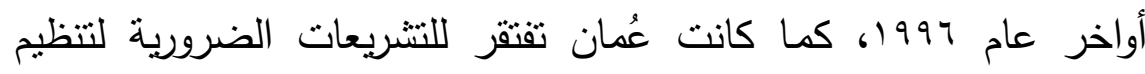

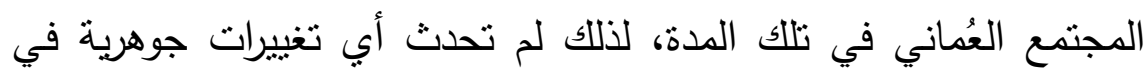

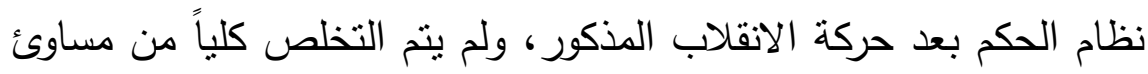

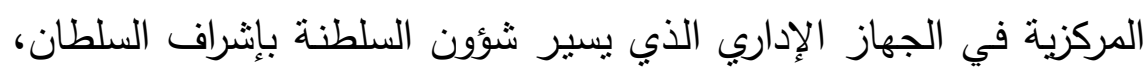

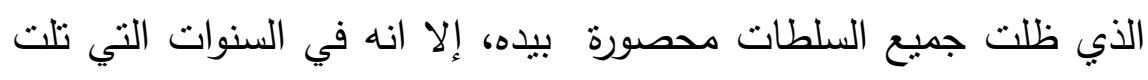

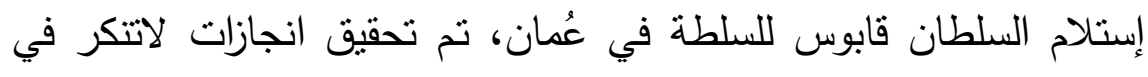

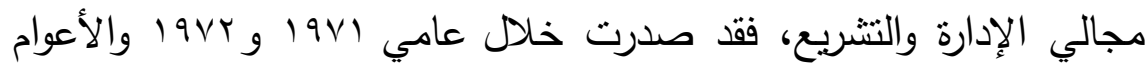

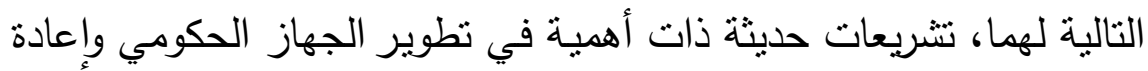

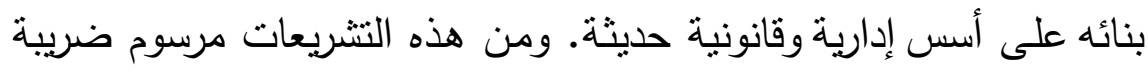

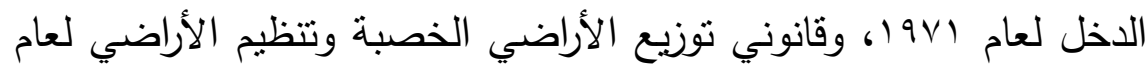

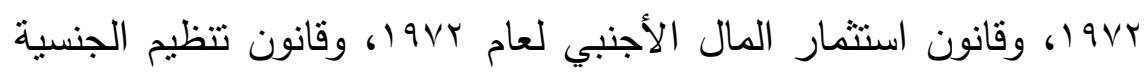




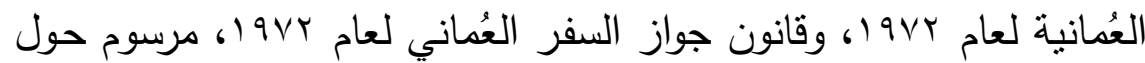

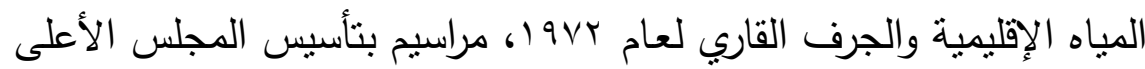

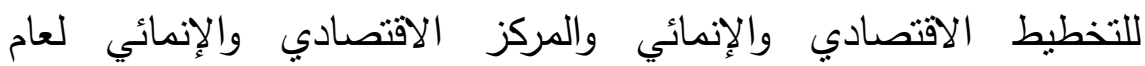

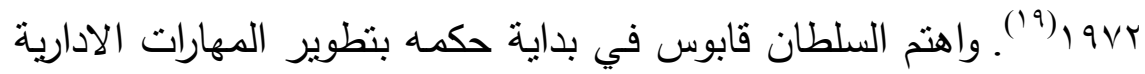

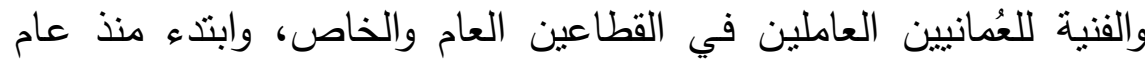

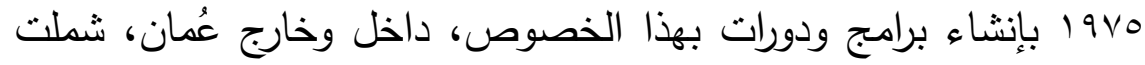

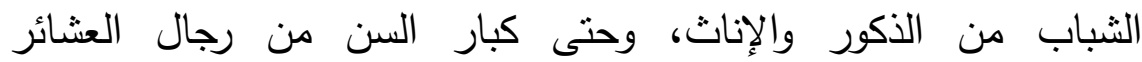

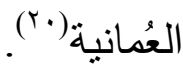

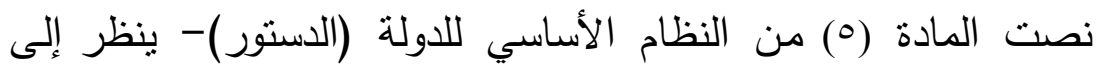

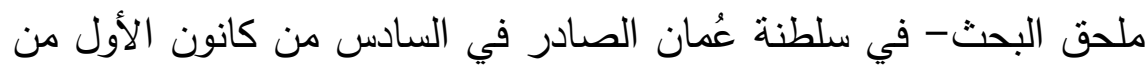

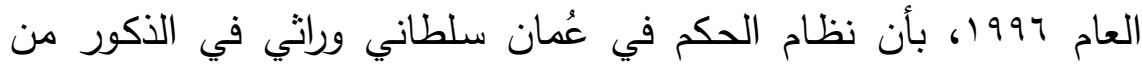

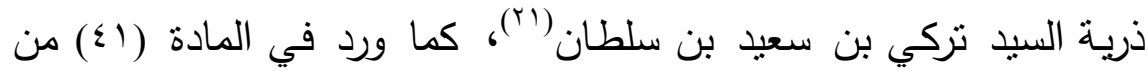
النظام الأساسي ذاته بأن السلطان هو رئيس الدولة والثئ والقائد الأعلى للقوات

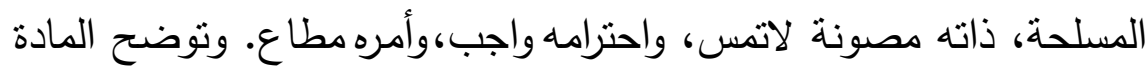

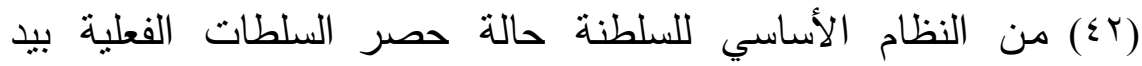

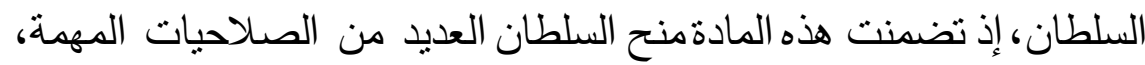

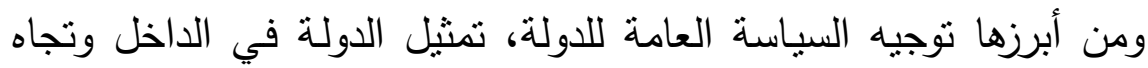

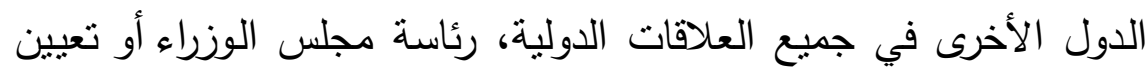
من يتولى رئاسته، تعيين نواب رئيس مجلس الوزراء والوزراء ومن في حكمه

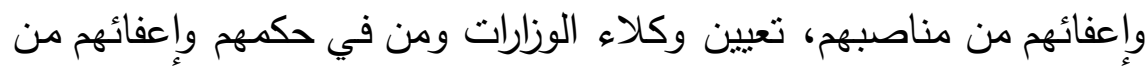

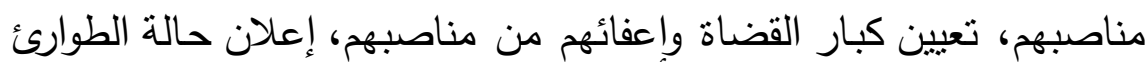

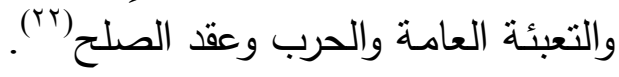
لم يكتبِ السلطان قابوس بالوثوب على السلطة و قمع حركة ظفار

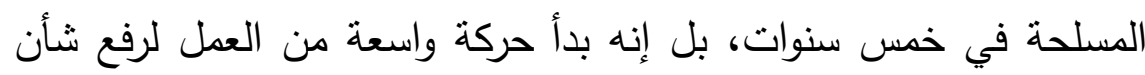

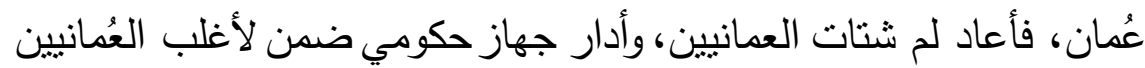


مستوى مقبول من العيش الكريم اللائق،ووضع أسس البنية التحتية، مستعيناً

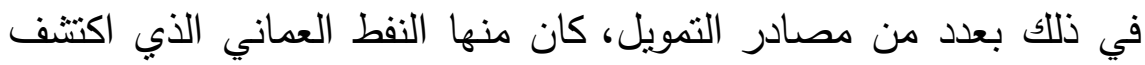

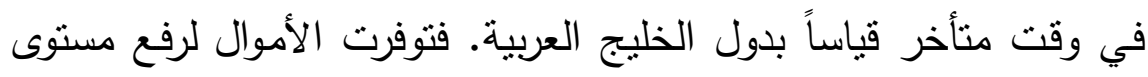
المعيشة في دولة كانت تفقتر أدنى مقومات العيش الكريم، فلم تعرف السلطنة قبل عهد السلطان قابوس البنية التحتية، ولم تكن هنالك الكثير من الطرق المرصوفة والمستشفيات والمدارس ولم يكن العمانيين يتمتعون بأدنى المقومات الطبيعية للعيش التي كانت تثمتع بها الدول المجاورة الأخرى، لقد جاء

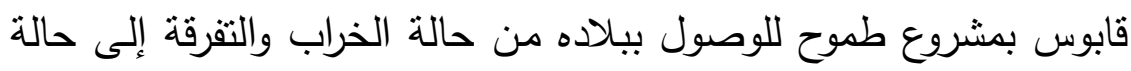

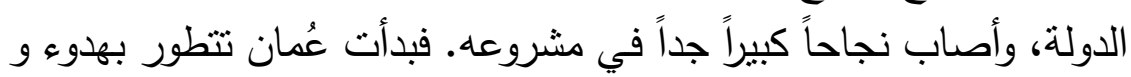

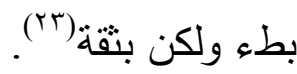
إن السلطان قابوس على علم عميق بلعبة التوازنات القبلية في عُمان، وبالولاءات القبلية، والإرتباط المباشر بالحاكم، لذا اعتمد منذ بدايات عكمه لونه

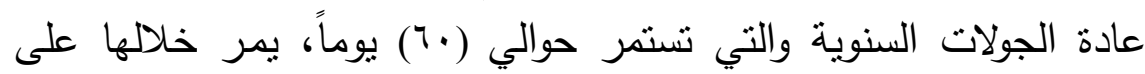

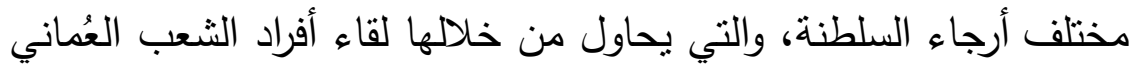
لسماع مطالبهم، ومتابعة الإنجازات التي تمت وتحديد المطلوب إنجازه،

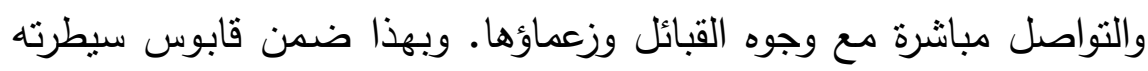

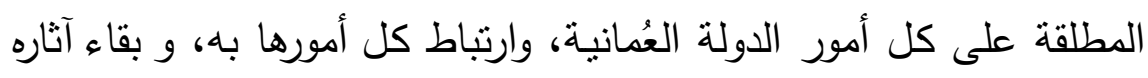
في كل أجزاءها ومنها سلاسل مساجد السلطان قابوس المنتشرة في طول البلاد وعرضها، والطرق و المنشآت المسماة باسمه، إن الهدف الرئيسي

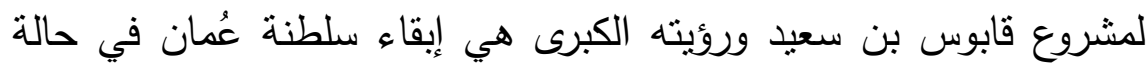

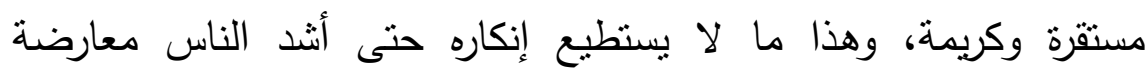

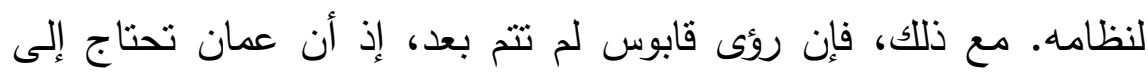
الاستمرار في التتمية، وإلى تصحيح مساراتها، وتلافي الخلل الذي ظهر في في إني بنية المجتمع العماني جراء نمطية السياسة الداخلية لنظام السلطنة، وعدم ولئي 
تكيفها مع التطورات المعاصرة، وضعف إستجاباتها للحاجات المتزايدة

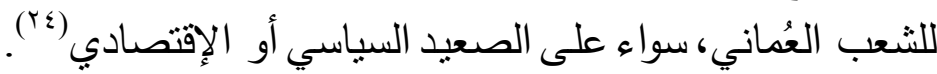

\section{ب- مجلس الوزراء}

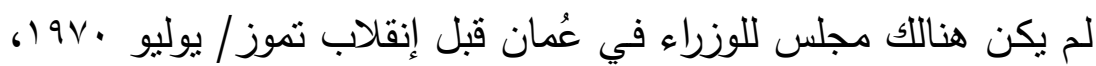
إذ كان السلطان السابق سعيد بن تيمور يعتمد في تسيير الإدارة الحكومية

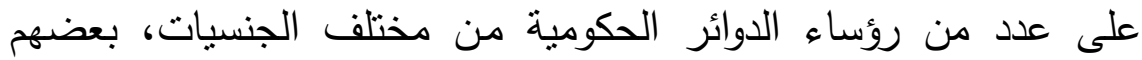

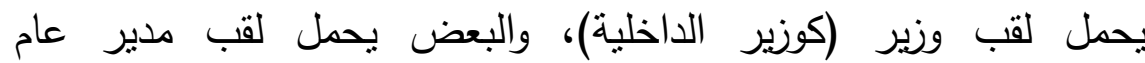
(كمديرعام الكمارك)، والبعض الآخر يحمل لقب سكرتير (كسكرتير الثؤون

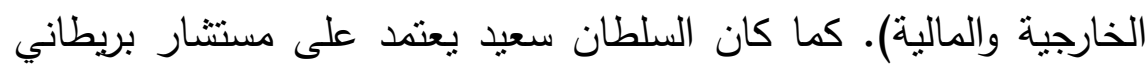
خاص وسكرتيرين آخرين للثؤون العسكرية ولثؤون التتمية. وقد كان مختلف الدوائر والوزارات الموجودة يتصلون مباشرةً بالسلطان لأخذ نوجيهاته ولهنه في مباشرة مسؤولياتهم الإدارية. وبالرغم من أن نظام الحكم الداخلي بلاني

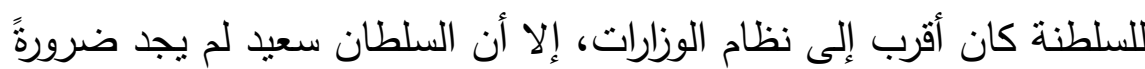
للتتسيق بين هذه الوزارات عن طريق إنشاء مجلس للوزراء يكون مسؤولاً مسؤولية تضامنية تجاهه (ro).

وعد السلطان قابوس في خطابه الذي وجهه للشعب العُماني في السادس والعشرين من تموز/يوليو • ا9 19عد نجاح حركته الانقلابية، بأنه سينشئ

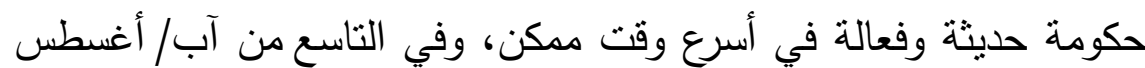
من العام ذاته عين السلطان قابوس عمه السيد طارق وفئ بن تيمور رئيساً للوزراءوكلفه بتشكيل الوزارة، وشكل طارق بن تيمور في الخامس عشر من

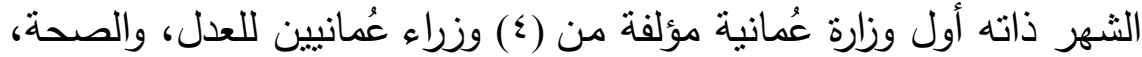
والتعليم، والداخلية. بينما احتفظ السلطان قابوس لنفسه بمنصب ورة وزئ وزير الخارجية، وبقي منصب سكرتير شؤون الدفاع في يد ضابط بريطاني، كما كان الوضع في السابق. ولكن الوزارة التي شكلها طارق بن تيمور قد تغيرت 
وجوهها فيما بعد، وألغيت بعض الوزارات بينما أجري تعديل على الوزارات

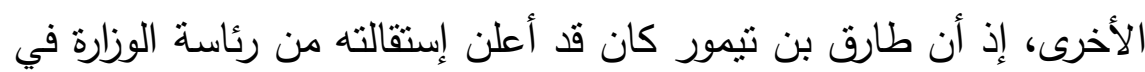

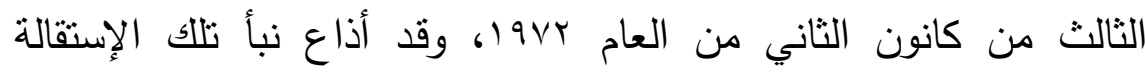

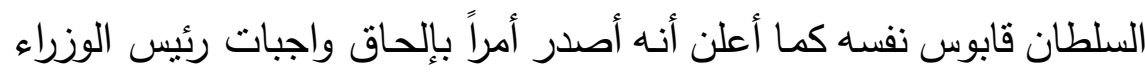

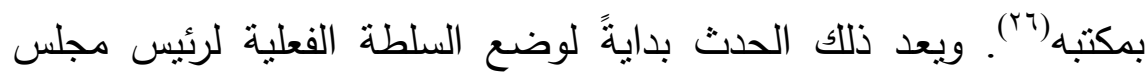

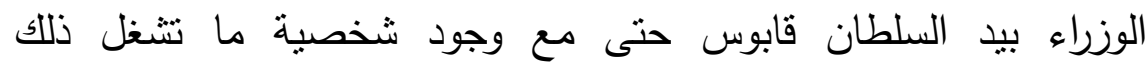

نصت المادة (rا) من النظام الأساسي لسلطنة عُمان على قيام مجلس

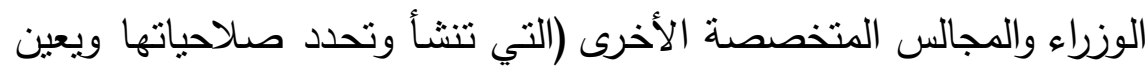
أعضاؤها بمقتضى مراسيم سلطانية معينة في أوقات معينة) بمعاونة السلطان

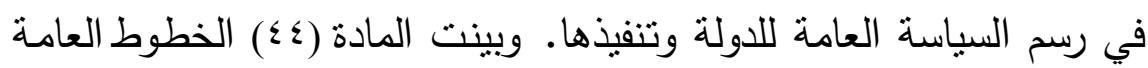

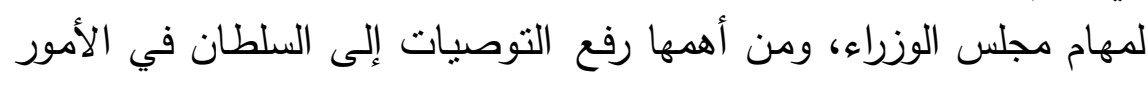

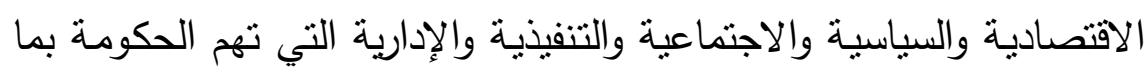

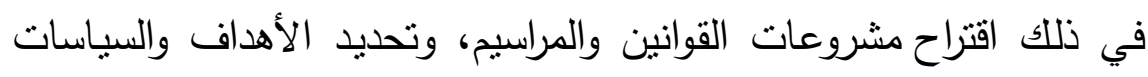

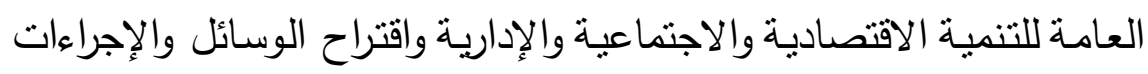

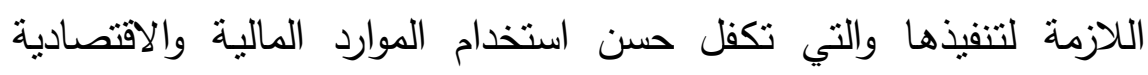

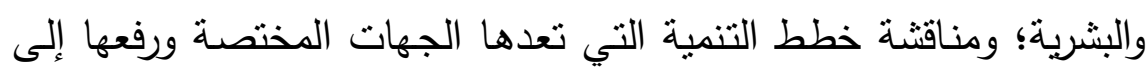

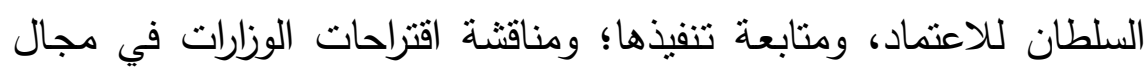

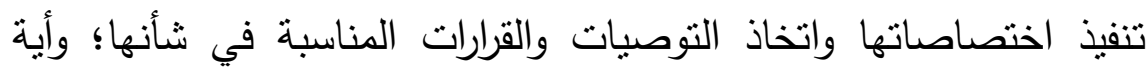

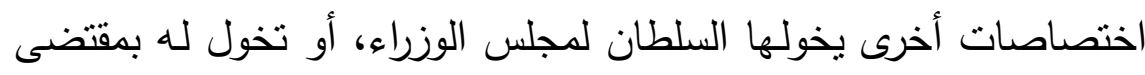

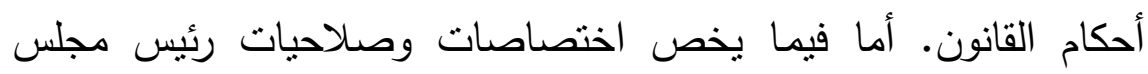

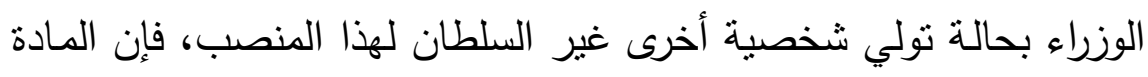

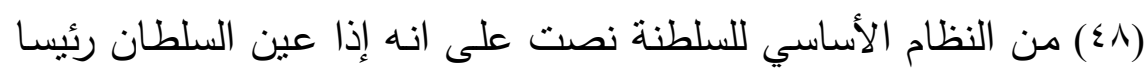

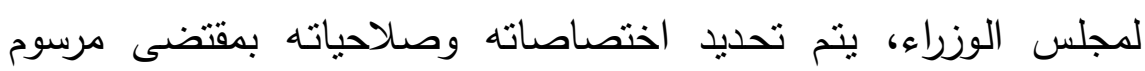
تعيينـ (rV) 
ج- الحياة النيابية في سلطنة عُمان

إن سلطنة عُمان تطبق نظام المجلسين التتريعيين، وهما (مجلس

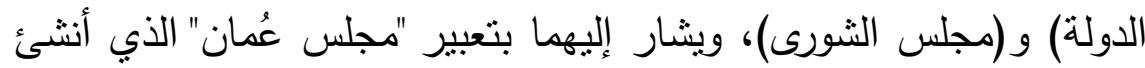

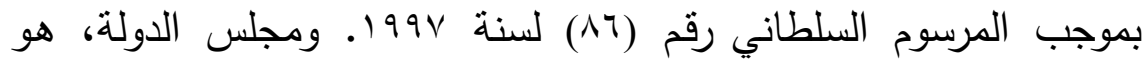

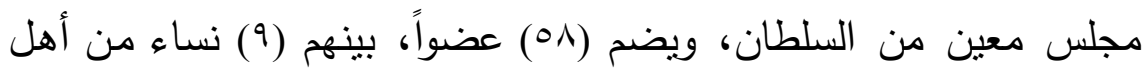
الخبرة والاختصاص، ويصنف مجلس الدولة بأنه الأعلى ضمن الدئه الدنظومة

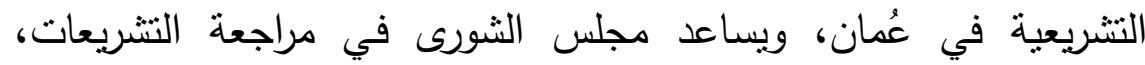
وتتضمن إختصاصات هذا المجلس إبداء الرأي والمشورة في برامج التنمية

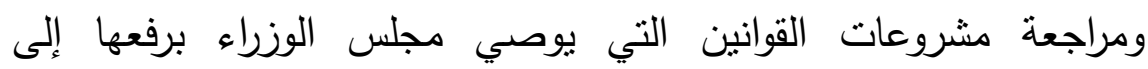
السلطان (r^). لعل أول تجربة للشورى في السلطنة ظهرت بإنشاء المجلس الإستشاري

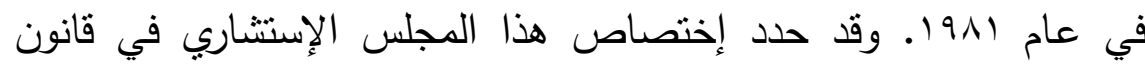

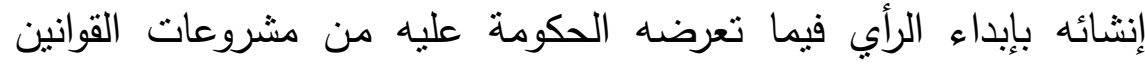

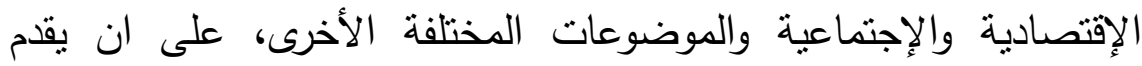

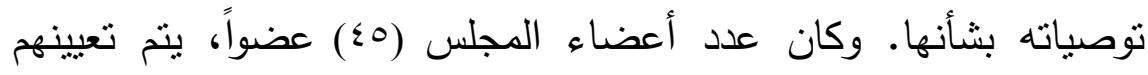
بمرسوم سلطاني. ثم أنشئ مجلس الثنورى العماني في عام النياء 1991 ليحل

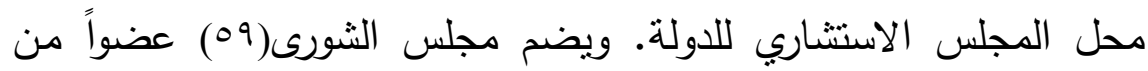

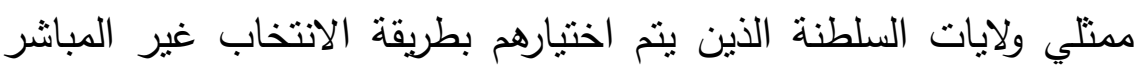

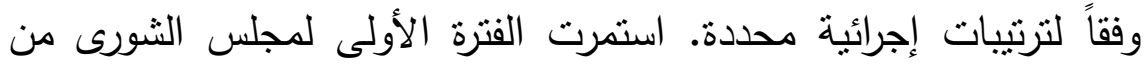

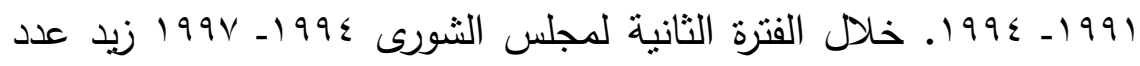

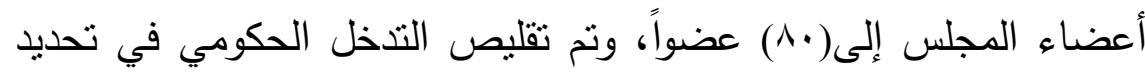

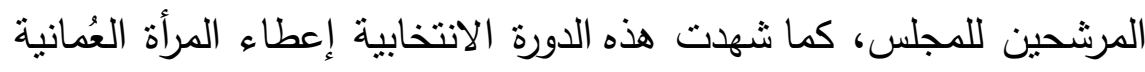

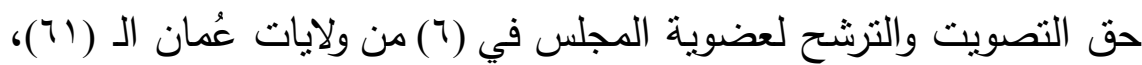

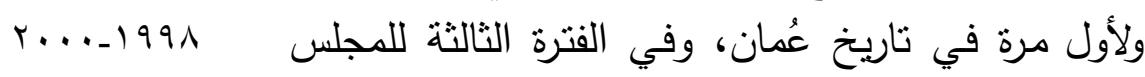


أعطيت المرأة حق التصويت والترشح في كل ولايات السلطنة، وقد فازت

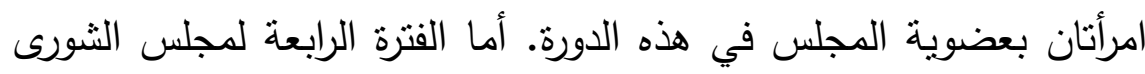

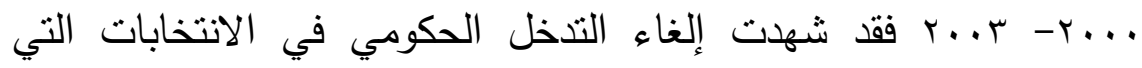

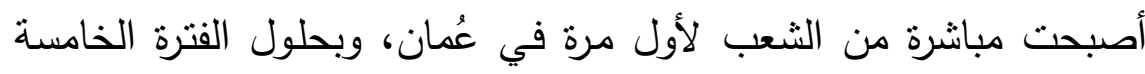

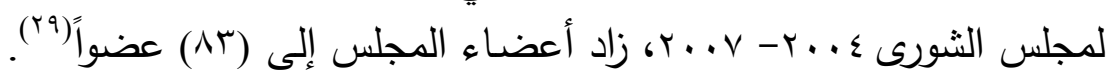

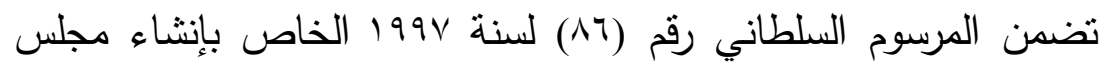

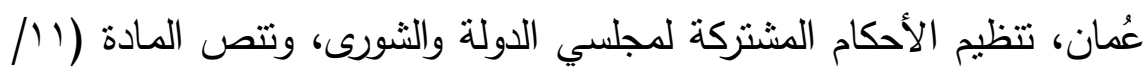

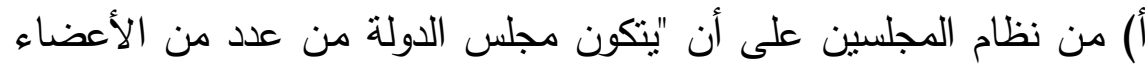

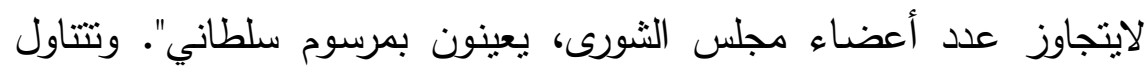

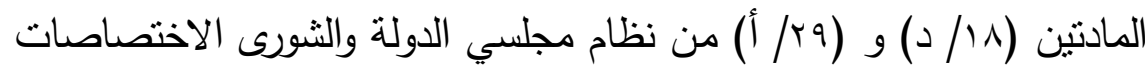

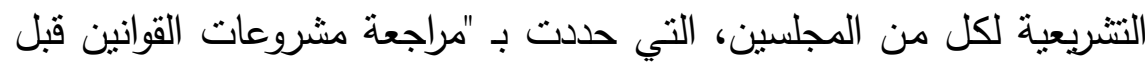

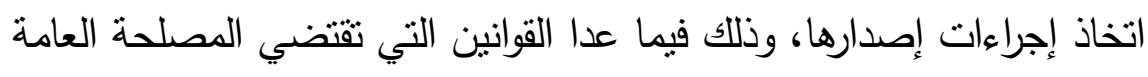

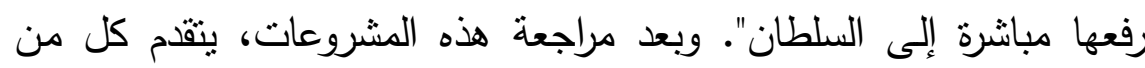

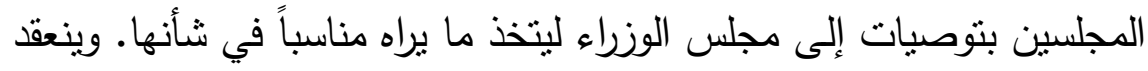

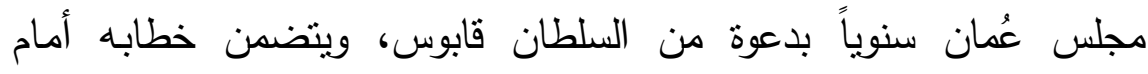

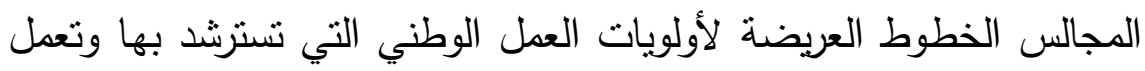

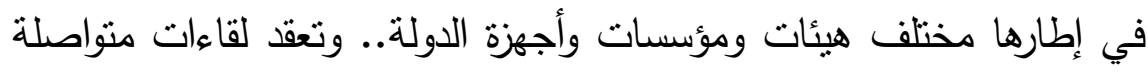

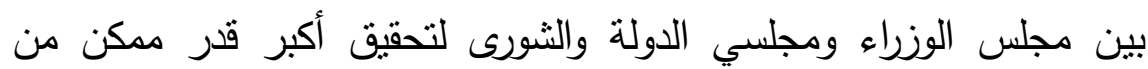

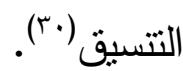

وبناء على ما تقدم فإن مجلس عُمان المشكل من مجلس الدولة ومجلس

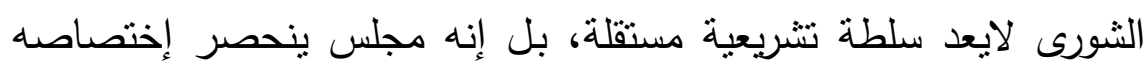

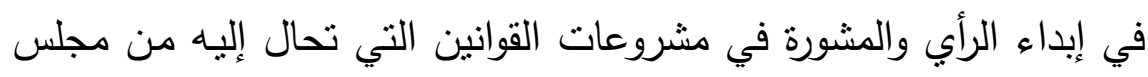

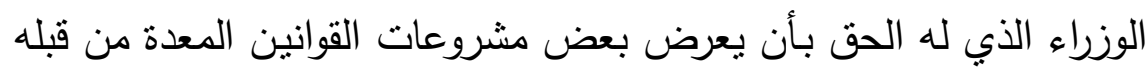

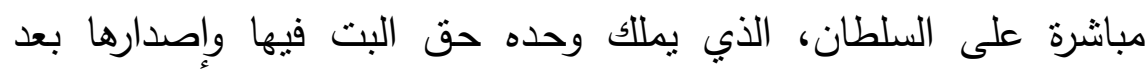


التصديق عليها، حين برى ذلك مناسباً، بوصفه رئيساً للسلطتين النتريعية

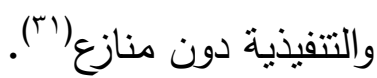
لقد شكل النظام الأساسي لسلطنة عُمان الصادر أواخر 1999 الإطار

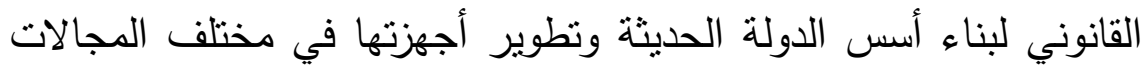

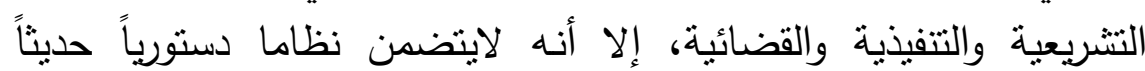
متكاملاً يقوم على فصل السلطات التشريعية والتتفيذية والقضائية وإستقلالها لألها عن بعضها، مع تعاونها، كما هو الحال في الدساتير الحديثة.

r- العوامل الداخلية المؤثرة في صنع القرار السياسي العُماني

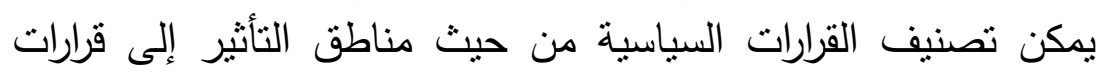

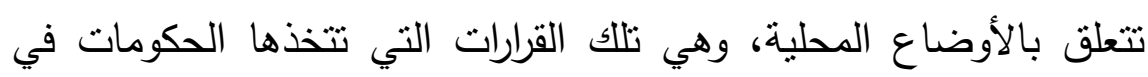

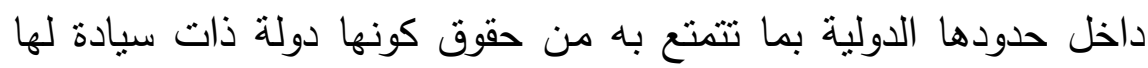

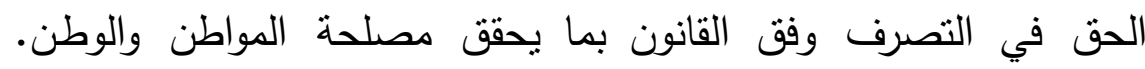

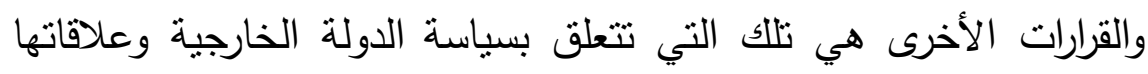

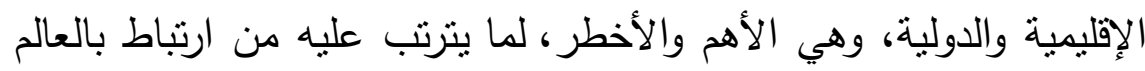

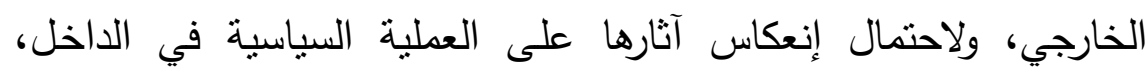

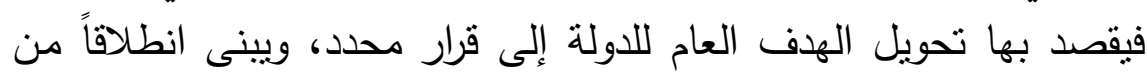

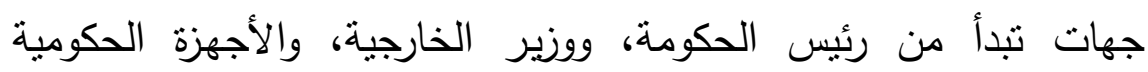
الأخرى، والسلطة التشريعية، ووسائل الإعلام والرأي العام (rانئ.

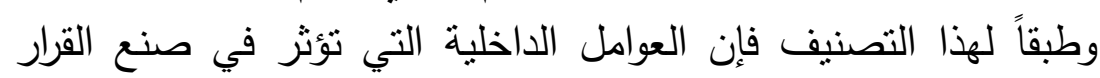

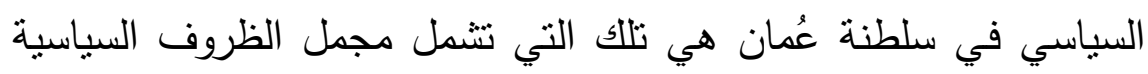

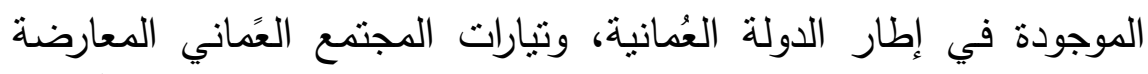

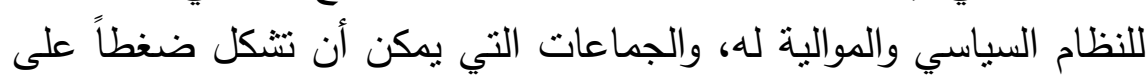

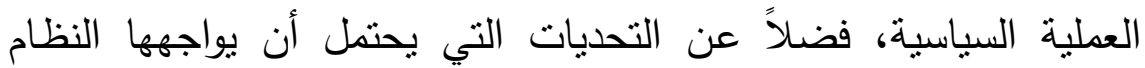


أ- الأوضاع السياسية داخل سلطنة عُمان

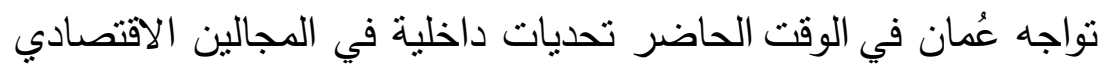

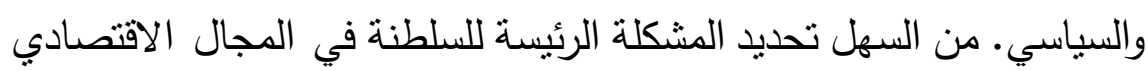

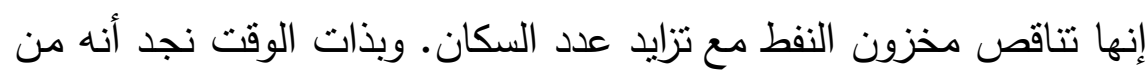

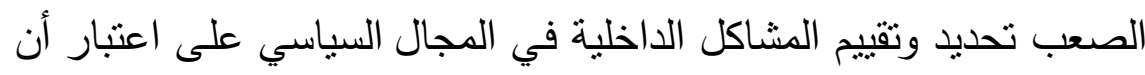

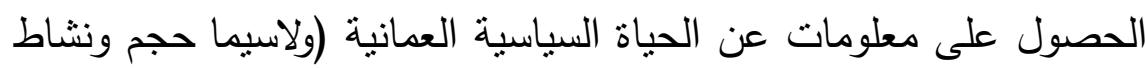

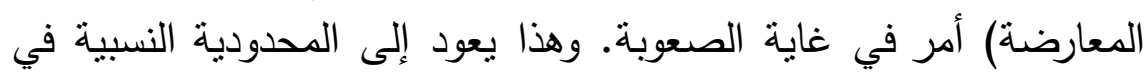

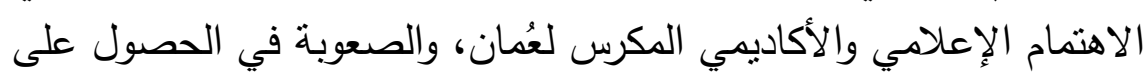

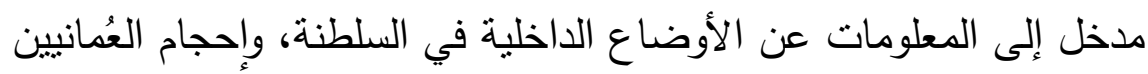

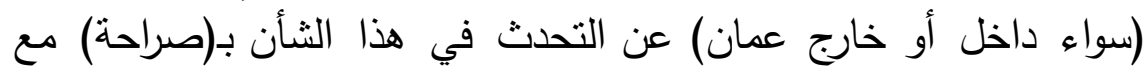

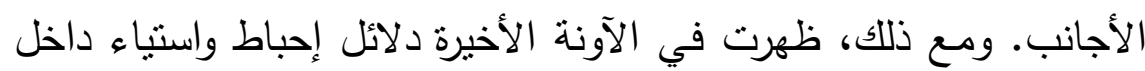

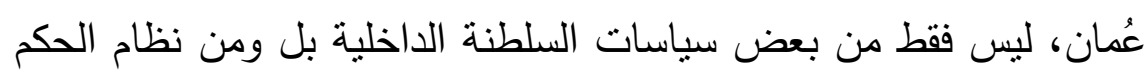

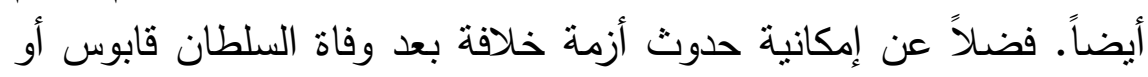

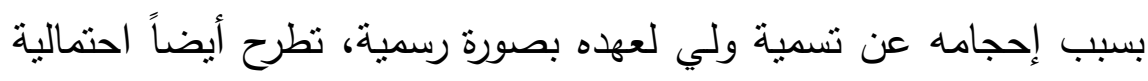
حدوث عدم استقرار في هذا البلد (rr).

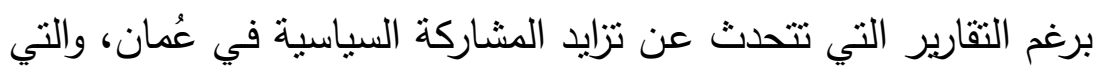

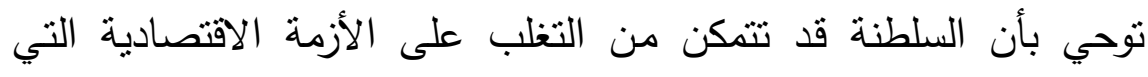

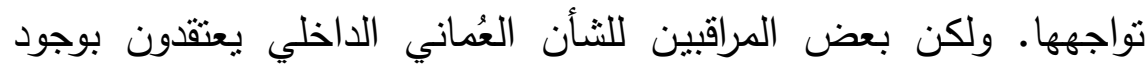

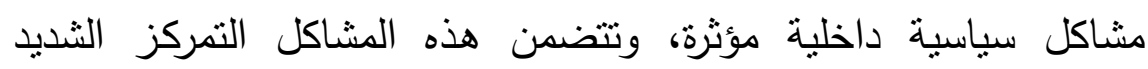

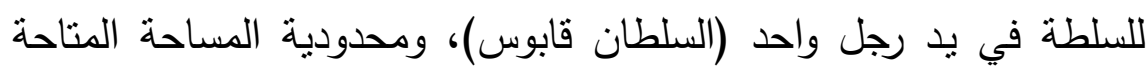

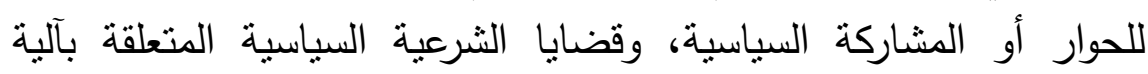

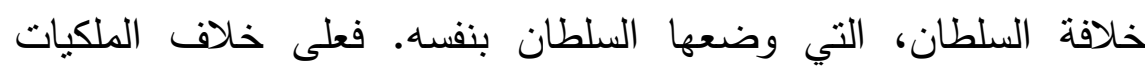

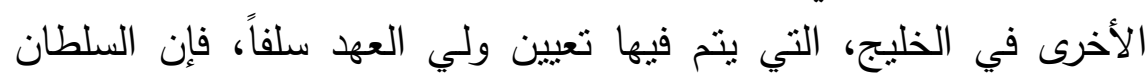

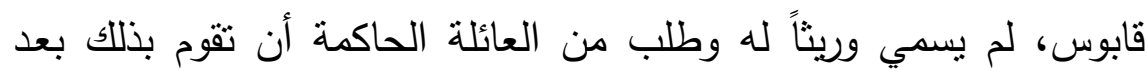


موته. وتتمتل المشكلة الأخيرة بوجود علامات متقطعة للمعارضة ولكنها

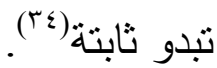

ويلاحظ في عُمان إن الأسرة الحاكمة، بصفتها مؤسسة حاكمة، ضعيفة، العانة وأن السلطان قابوس قد جمع بين يديه القسم الأكبر من السلطة وترك لأقربائه

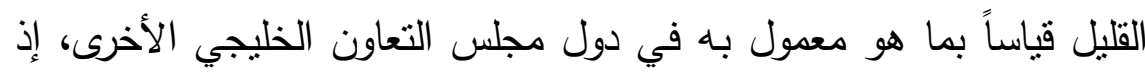
إن هنالك عدد قليل فقط من أقرباء السلطان الذين يشاركون في الحكومة،

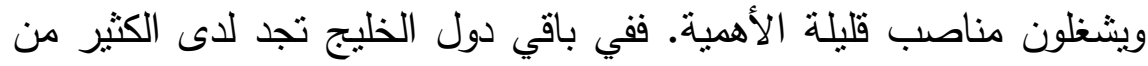

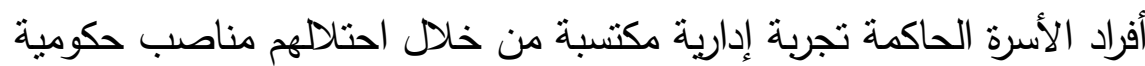
هامة، ولدى وفاة أو عجز الملك يكون ثمة أعضاء في الأسرة الحاكمة لديهم

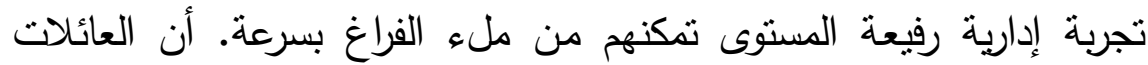

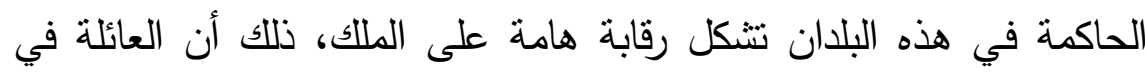

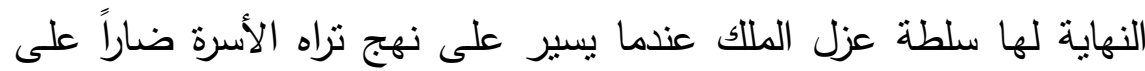
استمرارية حكم الأسرة الحاكمة. بينما لم بسمح السلطان قابوس لأحد من عائلة

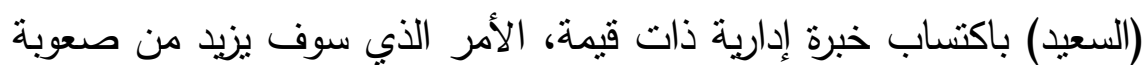

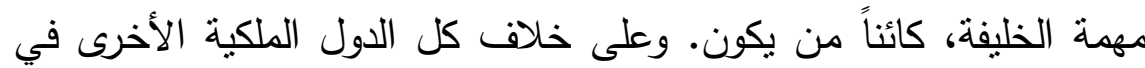

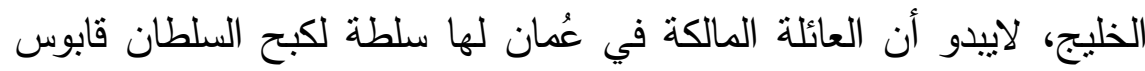

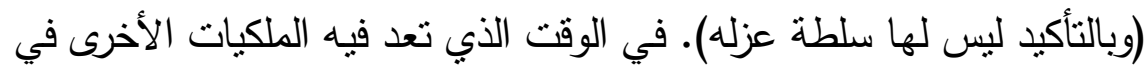

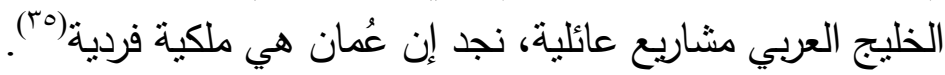

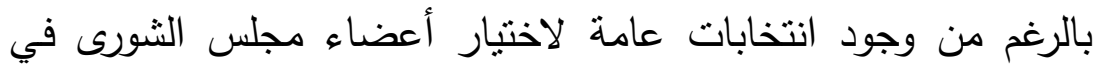

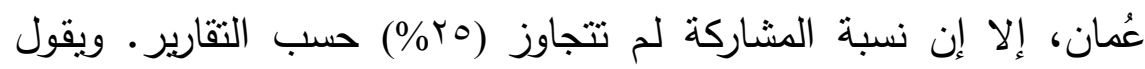

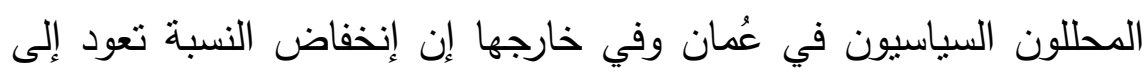

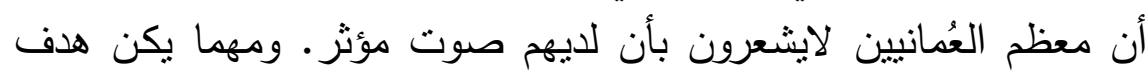

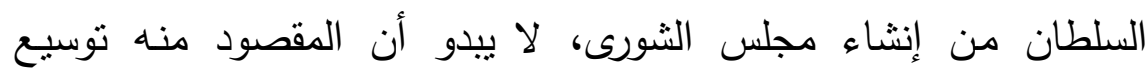

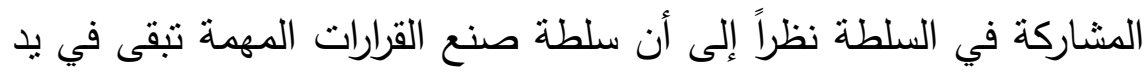

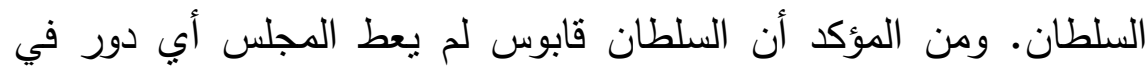


تقرير موضوع ولاية العهد. فقابوس ليس له أولاد، ولم يقم بتسمبة أياً من

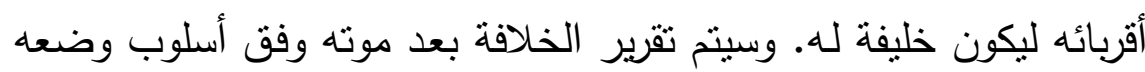

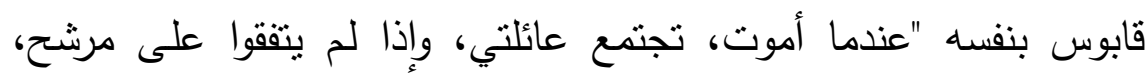

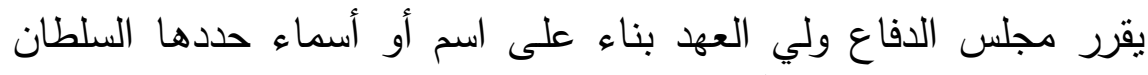

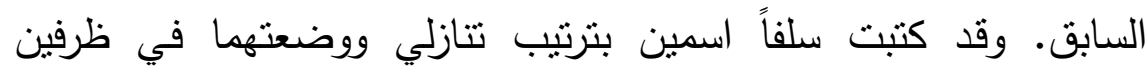

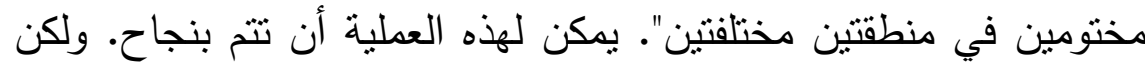

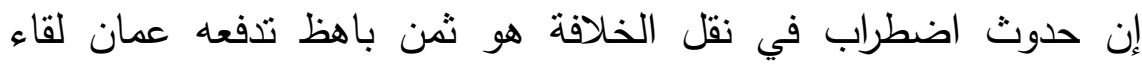

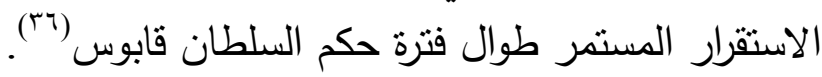

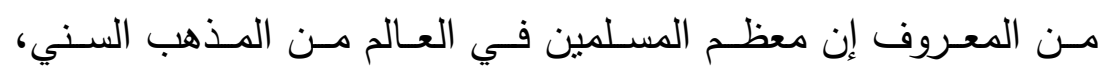

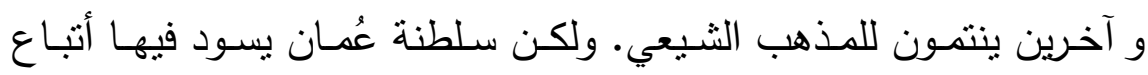

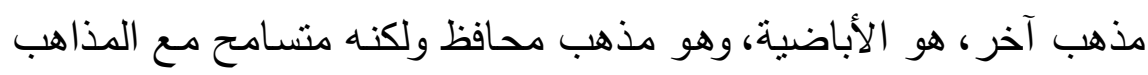

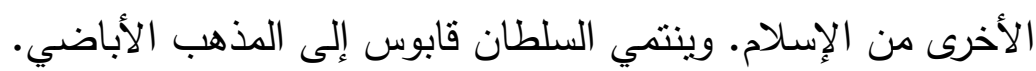

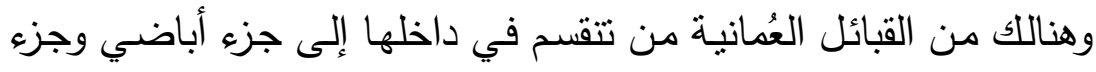

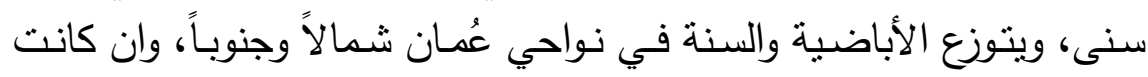

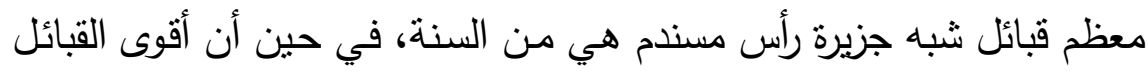

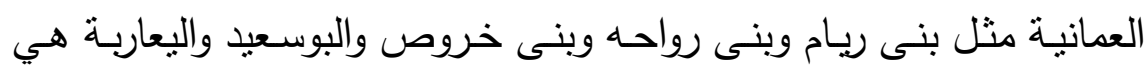

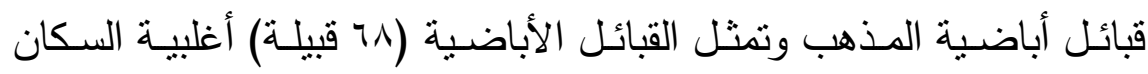

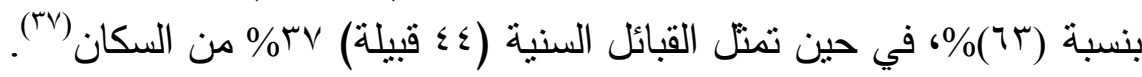

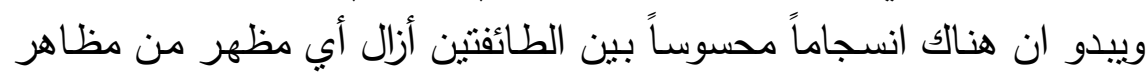

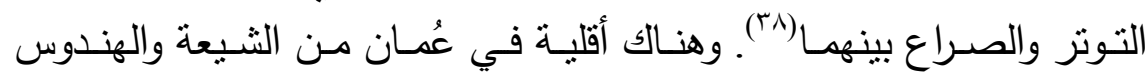
(أغلب الهندوس من العمالة الآسيوية الوافدة).

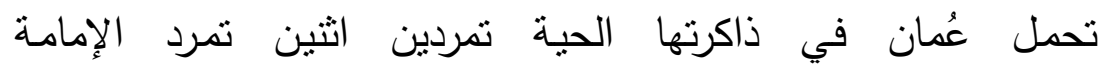

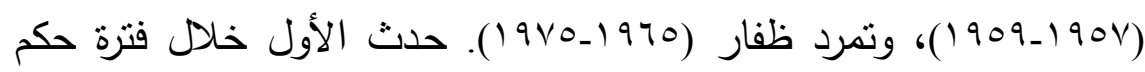

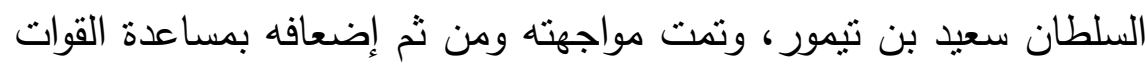

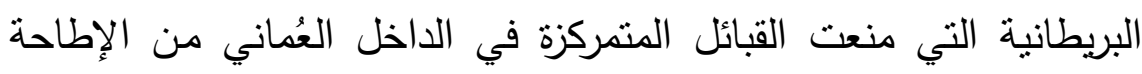


بنظام السلطنة المتمركز في مسقط وأجزاء من الساحل العُماني("ج").

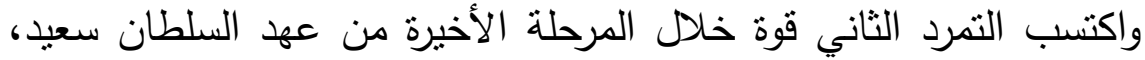
لكنه فقد قوته وهزم في عهد السلطان قابوس الذي استخدم إستراتيجية مغايرة لنهج والده لمواجهة هذا التمرد، إذ حرص على كسب عقول وقلوب

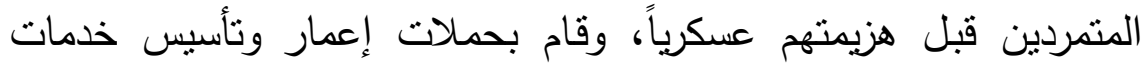

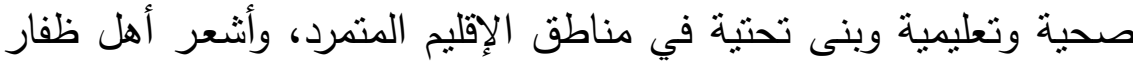

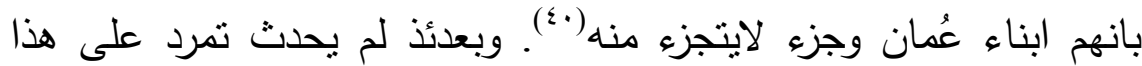
المستوى منذ السبعينات.

ولكن ظهر نشاط معارض في عُمان منذ منتصف التسعينات، وكان هذا النشاط على خلاف التمردين الأولين، موجها ضد السلطان قابوس على على نحو ملند

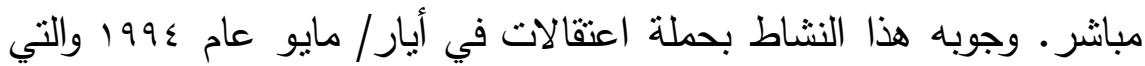
شملت مئات "المناوئين" للنظام. ويبدو أن المعتقلين لم يكونوا يطالبون بإسقاط نظام السلطنة بل بإصلاحها. وكان من بين المعتقلين عدد من الموظفين

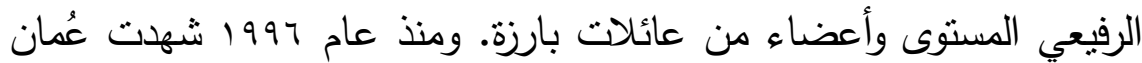
تعبيرات عامة عن الاسنياء على شكل مظاهرات طلابية عارضة ومنشورات

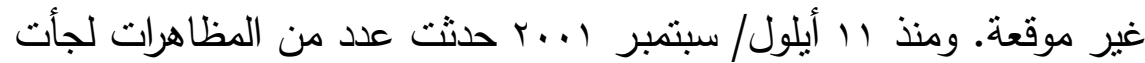

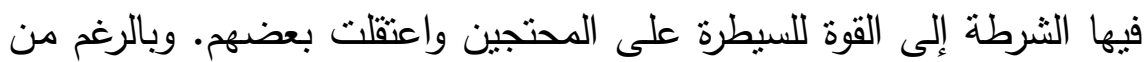

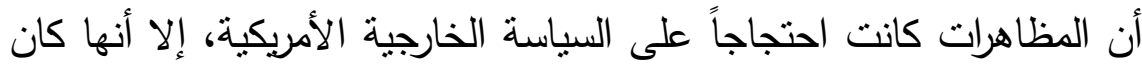
يمكن أن ثُرى على أنها نقد لسياسة العلاقات الوطيدة مع واثنطن التي ينتهجها

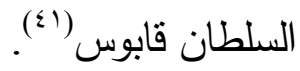
تأثز قسم من العُمانيون بحركات الاحتجاج الثعبية التي اجتاحت الدول

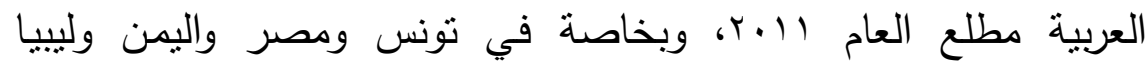
وسوريا، فخرجت مظاهرات شعبية في سلطنة عُمان وحدثت بعض فئ الاعتصامات في الأثهر الأولى من ذات العام. رفعت نلاتك الاحتجاجات

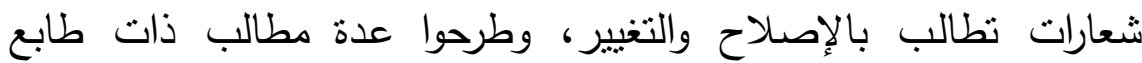




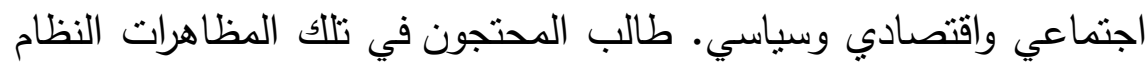
بإجراء المزيد من الإصلاحات السياسية. وقد اكتسبت الاحتجاجات

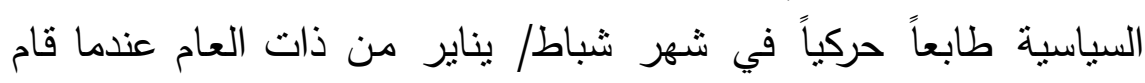

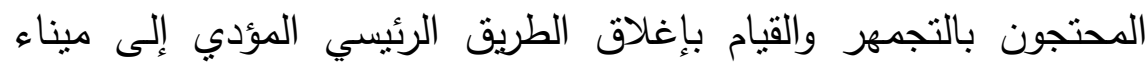

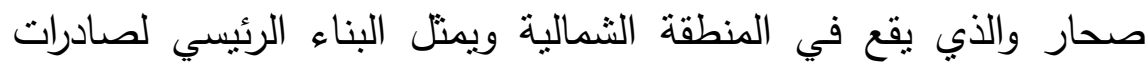

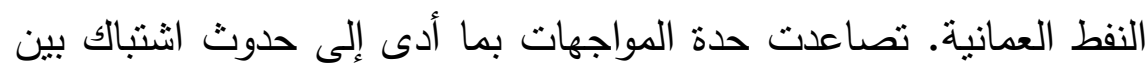

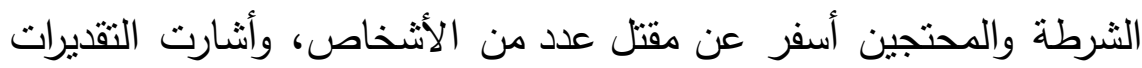

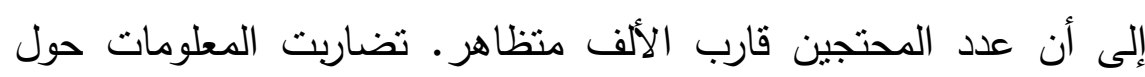

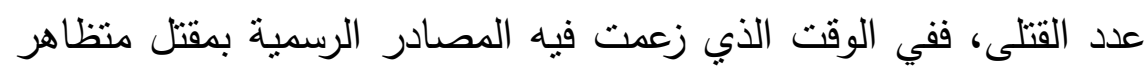

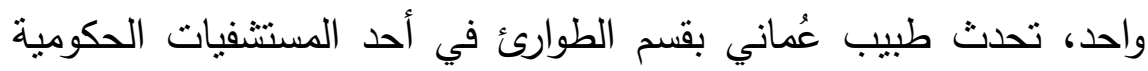

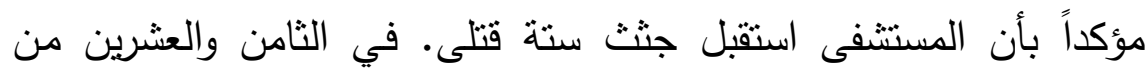

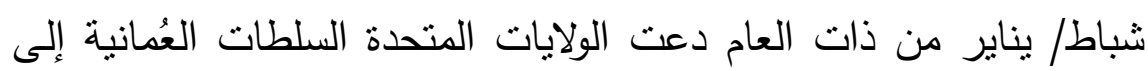

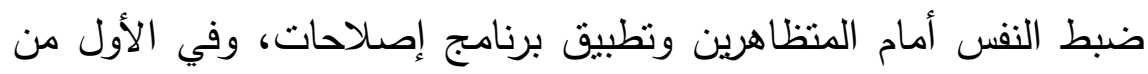

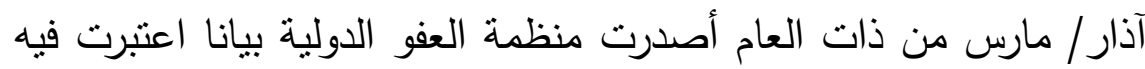

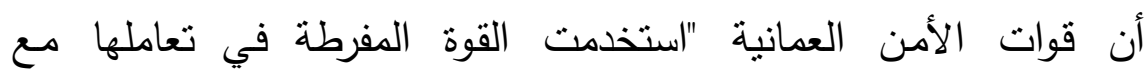
الدحتجين"، ودعت السلطات إلى "احترام حق النظاهر السلمي". وترافقت المظاهرات مع بعض أعمال العنف التي شملت نهب الهرات المتاجر وإثعال

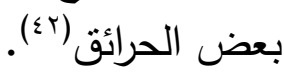
على أثز هذه الاحتجاجات، قالت وكالة (أسوشيتد برس) الإخبارية في

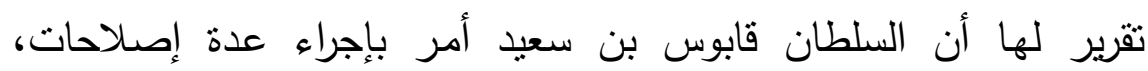

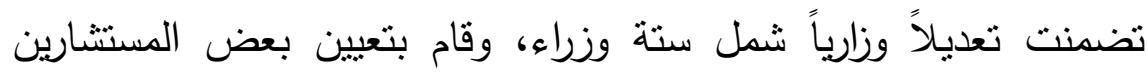

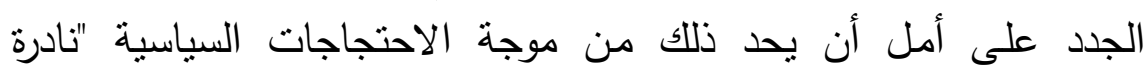

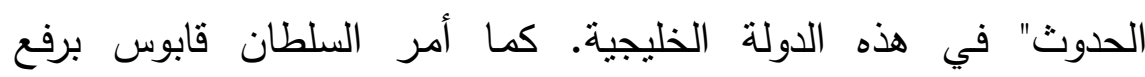
المخصصات المالية الثهرية لطلبة الكليات والمعاهد والمراكز الحكومية الكية الكانية

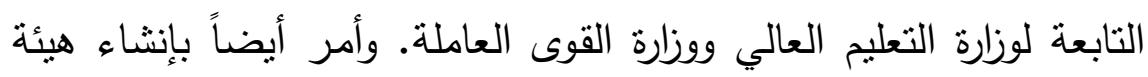


مستقلة لحماية المستهلاك. في حين أمر السلطان قابوس بن سعيد بتوفير

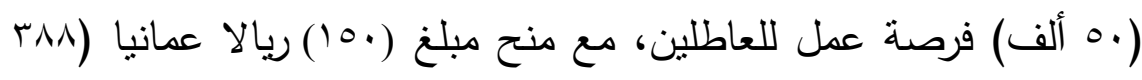
دولارا) شهريا لكل باحث عن عمل من المسجلين للى وزارة القوى العاملة

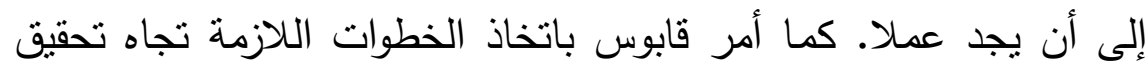

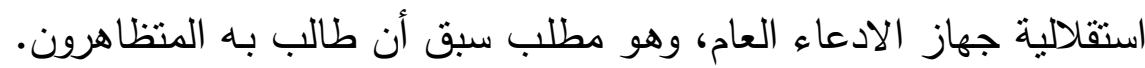

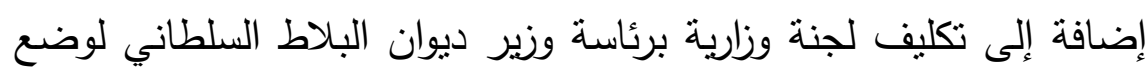

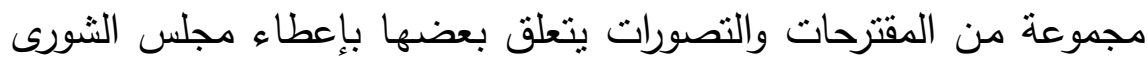

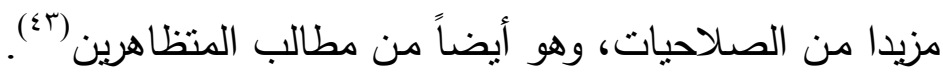

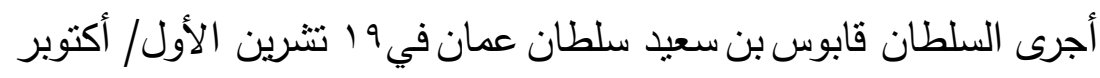

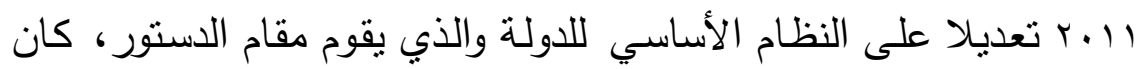

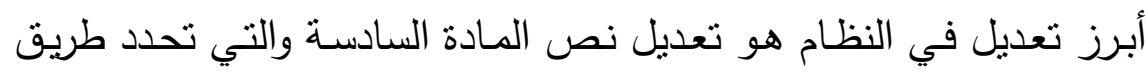

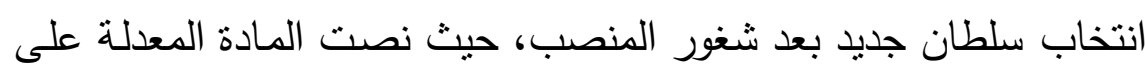

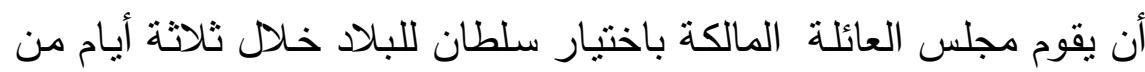

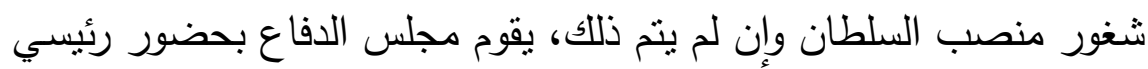

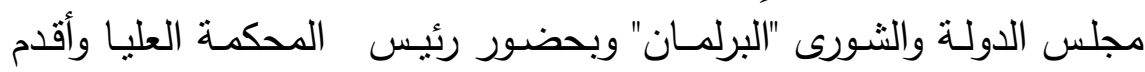

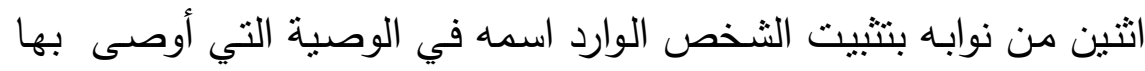

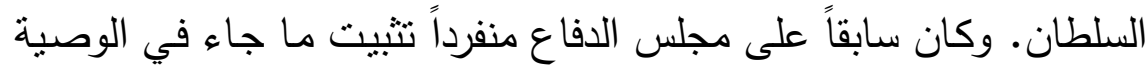

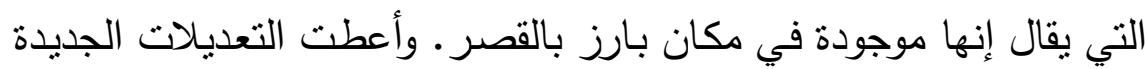

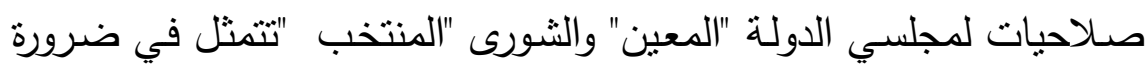

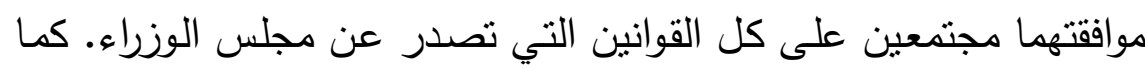

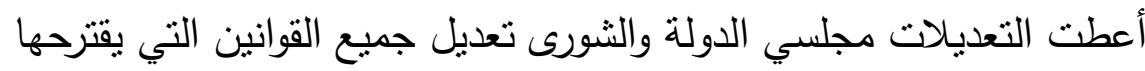

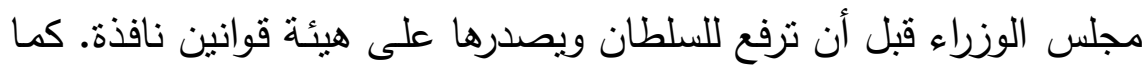

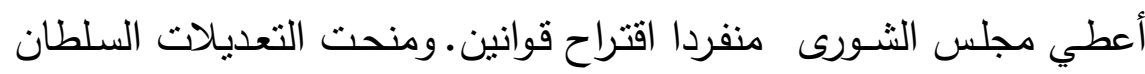

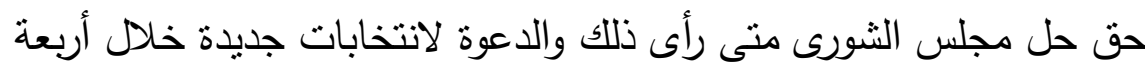

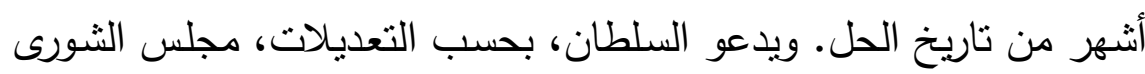


للانعقاد في جلسة سرية لانتخاب رئيس للمجلس ونائبين للرئيس فيما كان

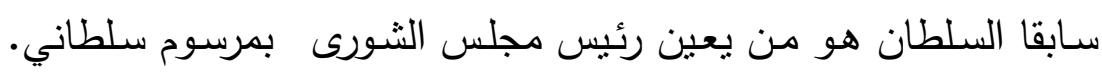

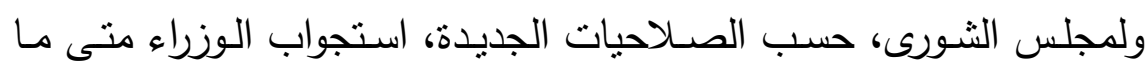

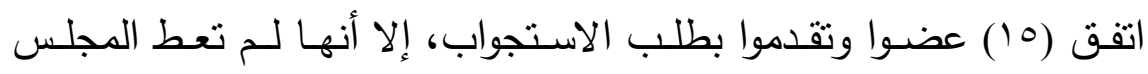

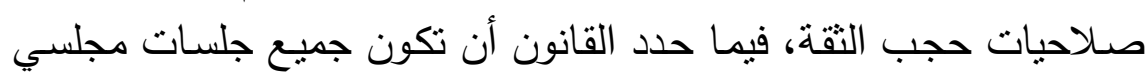
الدولة والثورى علنية، إلا أن تم الاتفاق على أن تكون سرية ولا بد أن تتم

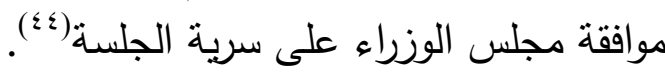
إن المسألة الملحة في معظم البلدان العربية ليست مسألة الديمقراطية، بل إنها إقامة نظام سياسي فعال قادر على مواجهة تحديات التغيير ، بدلاً

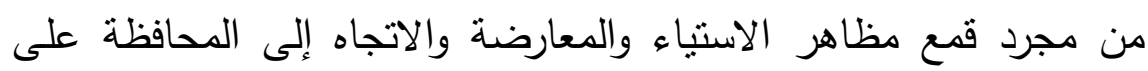

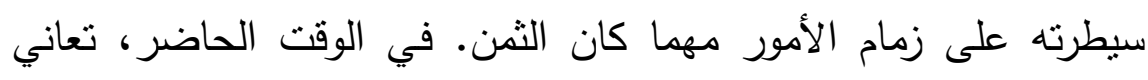

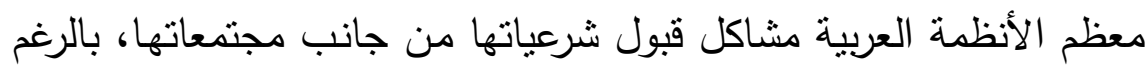
من استمرار قوة أجهزتها القمعية. فهذه الأنظمة لا تعرف الوسائل فئل لإمكانية

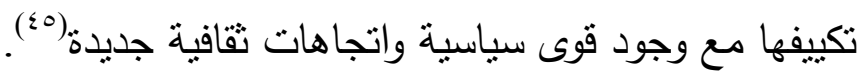

\section{ب- التحديات الإقتصادية المواجهة لسلطنة عُمان}

سعت الحكومة العُمانية إلى زيادة نسبة العُمانيين العاملين في القطاع

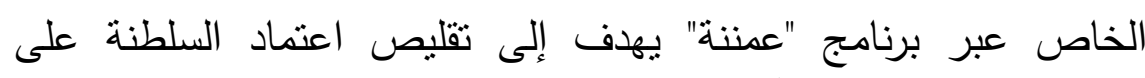

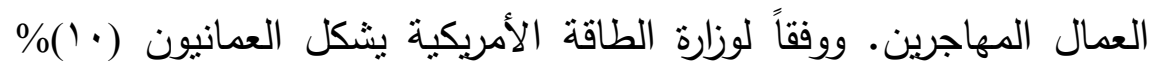
فقط من العمالة في القطاع الخاص. وفي منتصف عام ء ـ... تم تقدير

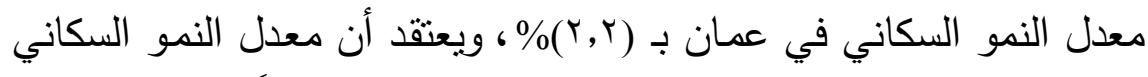

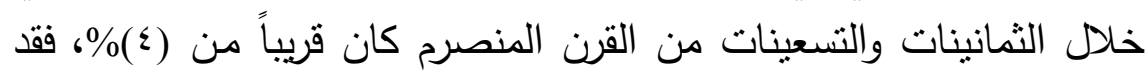

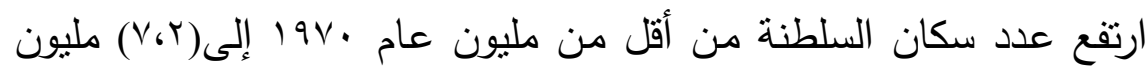

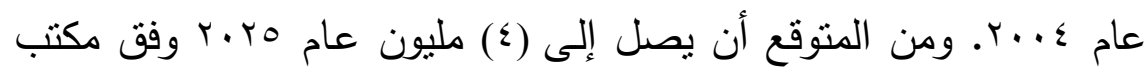




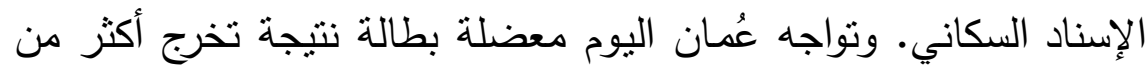

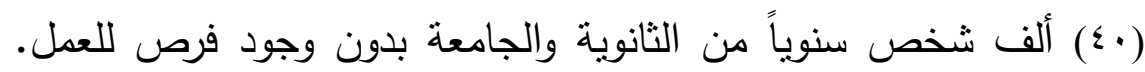

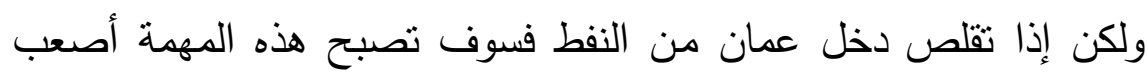

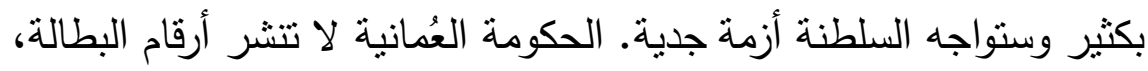

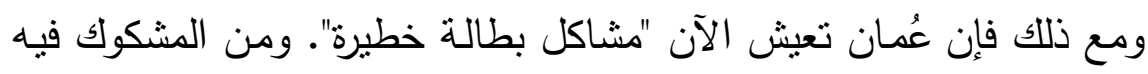

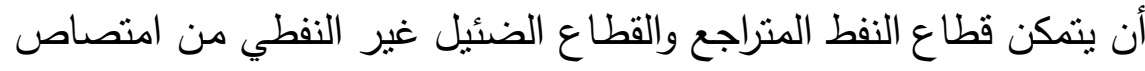

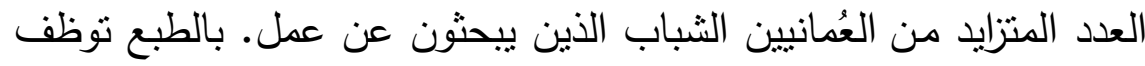

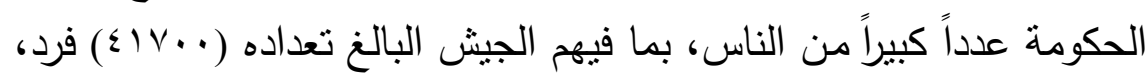

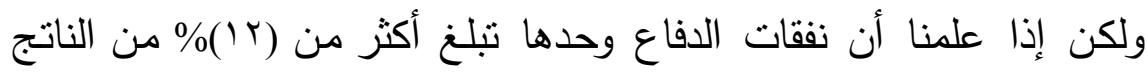

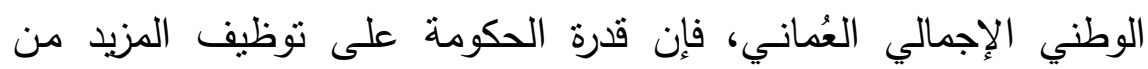

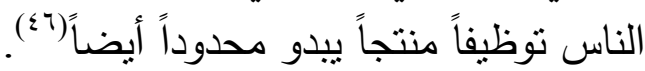
بالنظر إلى التزايد السريع في عدد سكان السلطنة، وكون احتياطي النفط

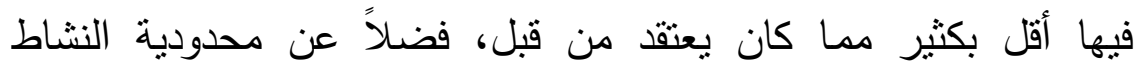

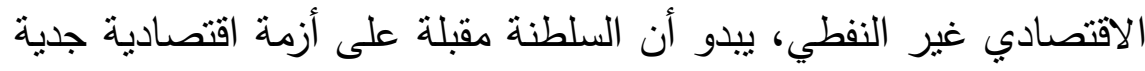

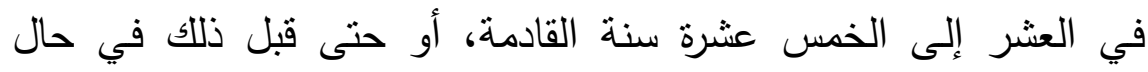

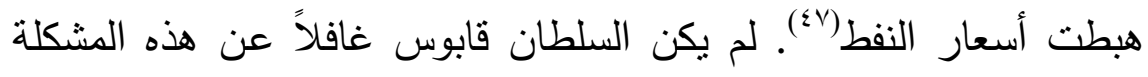

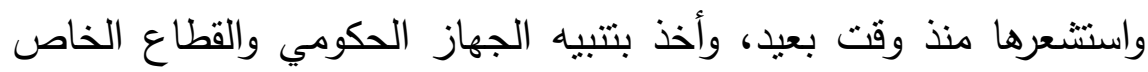

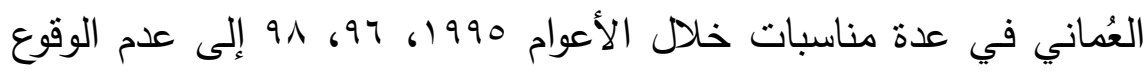

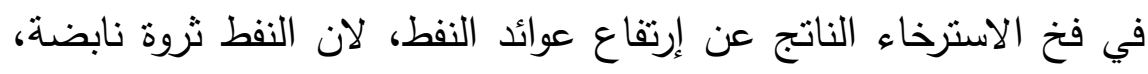

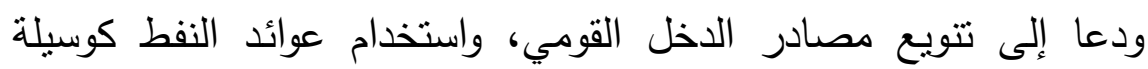

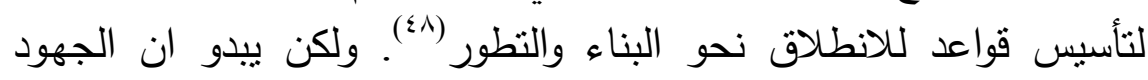

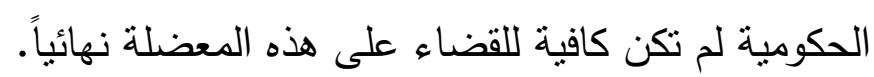

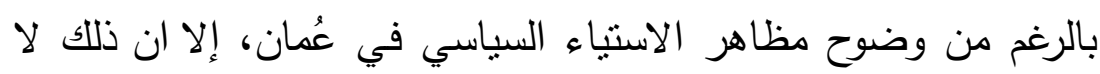

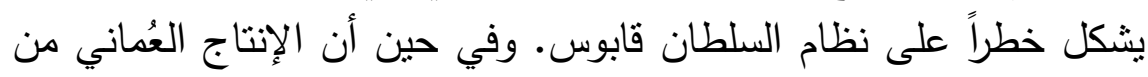

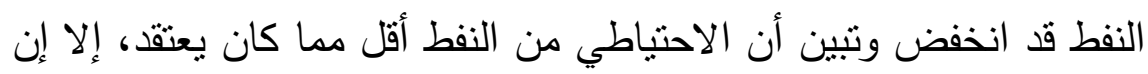


الإرتفاع الحالي لأسعار النفط قدم دعماً للأوضاع الإقتصادية في عُمان. وطالما أن الحكومة قادرة على تأمين مستوى لائق من المعيشة للعُمانيين

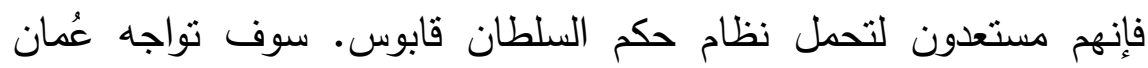

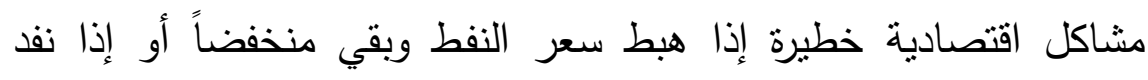
الاحتياطي من النفط أو إذا حصل كلاهما. إن تدهور الظروف هيط الاقتصادية

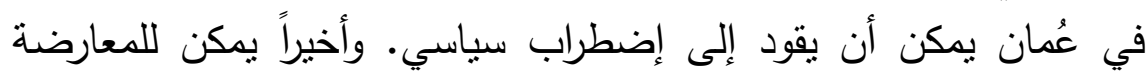

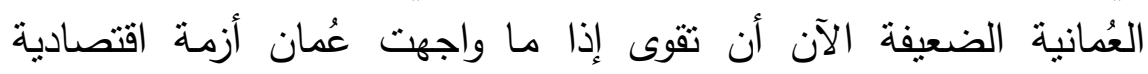

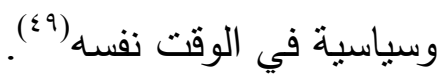

\section{ع - العوامل الخارجية المؤثرة في صنع القرار السياسي العُماني}

لم يكن هنالك في سلطنة عُمان قبل العام ، و9 19 ما بيمى بسياسة خارجية بالمفهوم المطلق والمركزي، بل إنه لم يكن هناك أصلاً دولة ألة بمفهومها

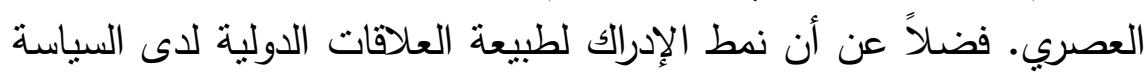

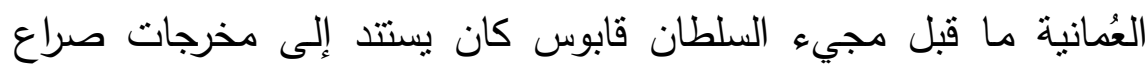

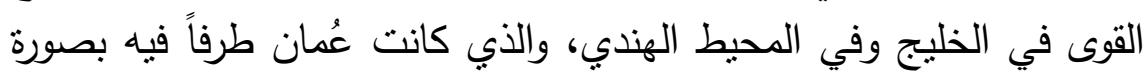
مستمرة. لذا، فإن الخبرة المستمدة من هذا الارتباط وهذا الاندماج قد شكانلا

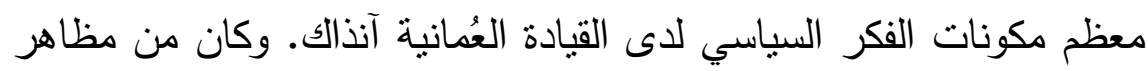
هذا الفكر أنه لم يعط أية أهمية أو أي اعتبار للأبعاد العربية أو الخليجية

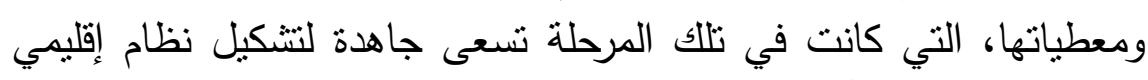
عربي، يكون مرنكزَاً للعمل العربي المشنرك، والذي كان يهدف إلى فئى إقامة

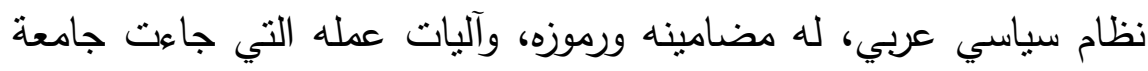
الدول العربية في مقدمتها. ولم ترضى التوجهات السياسية العربية وحركاتها

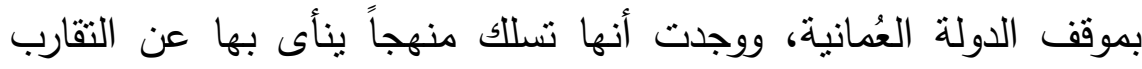

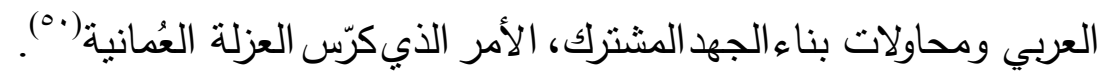




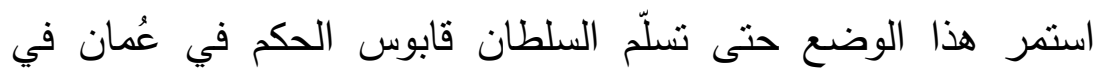
تموز/ يوليو من العام •ول1، وقام بإدارة السياسة الخارجية للاولة العُمانية

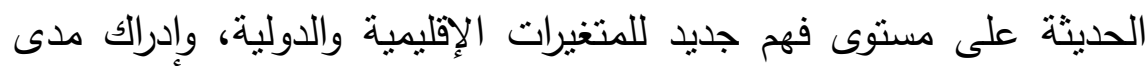

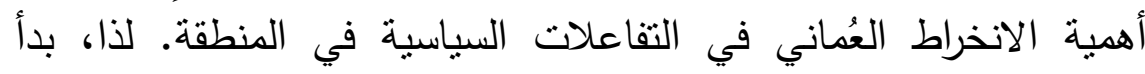

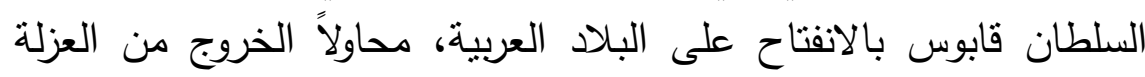

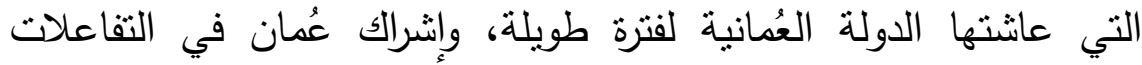

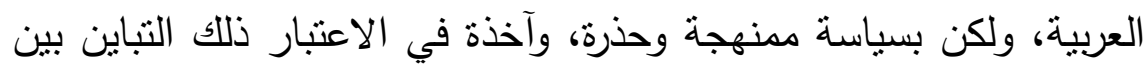

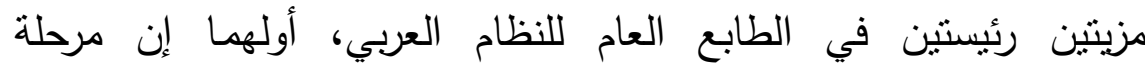

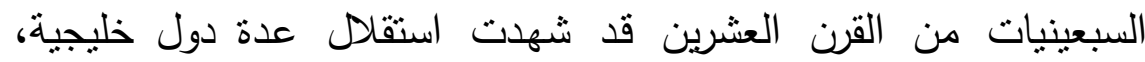

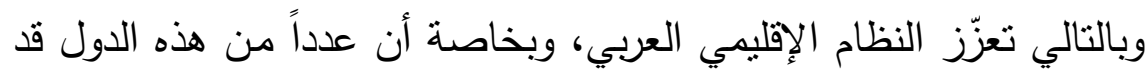

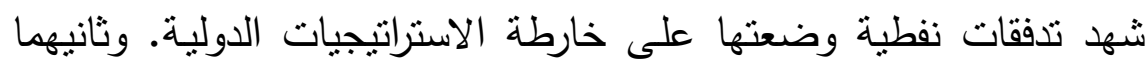

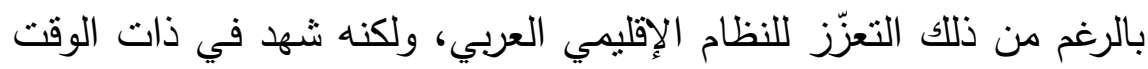

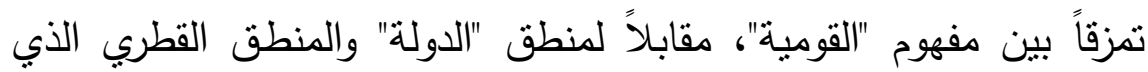

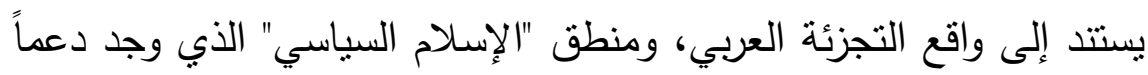

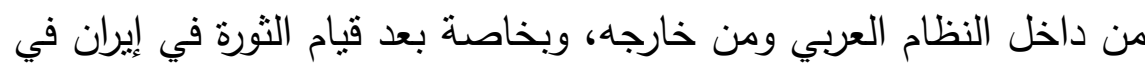

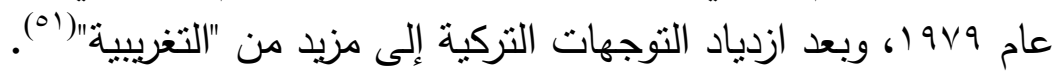

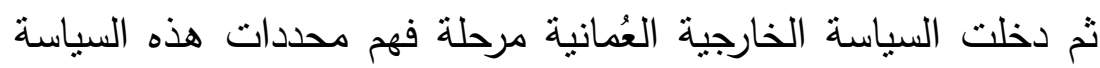

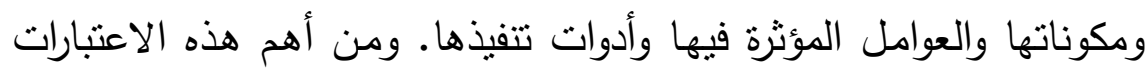

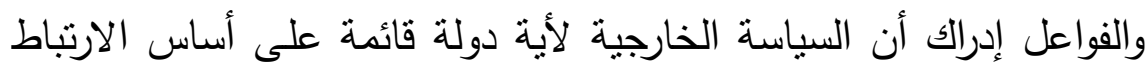

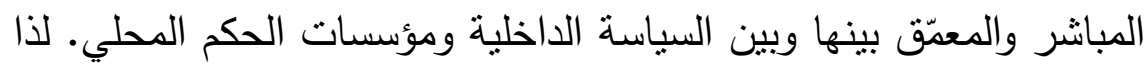

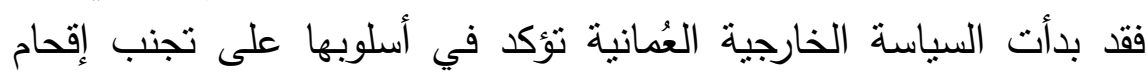

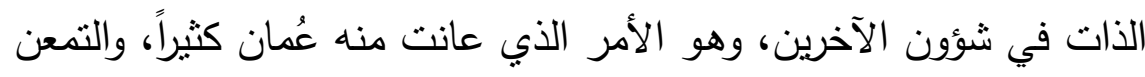

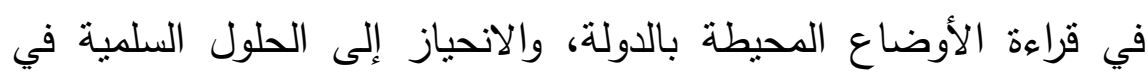

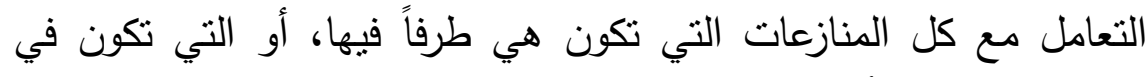

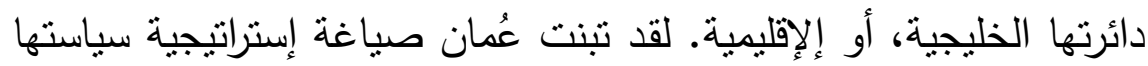


الخارجية عبر بناء خطاب سياسي يلتزم بما ينفق والثوابت للاولة، ويتوافق

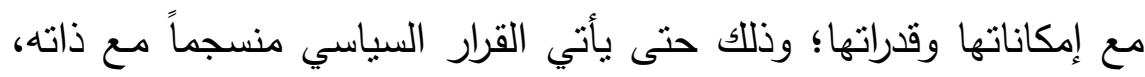
وأن يكون منواتراً على صورة واحدة يحكمها "الثنابت" ولانيات تحكمها الآنيّة

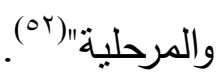

لقد تميزت السياسة الخارجية العُمانية بالواقعية والحياد، فبادرت بالتعامل

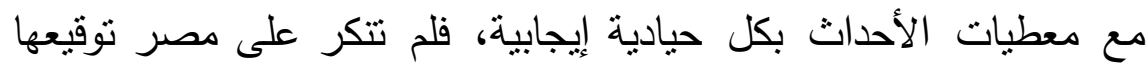

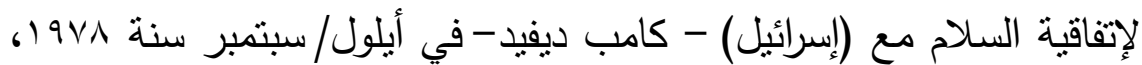

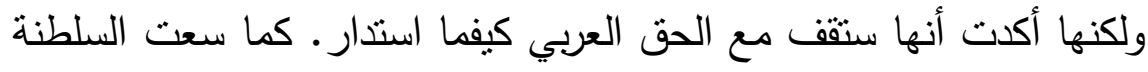

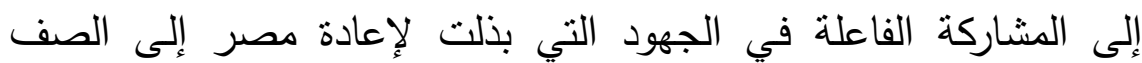

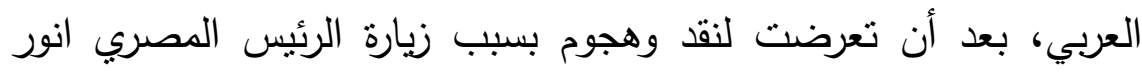

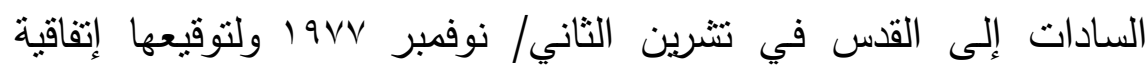

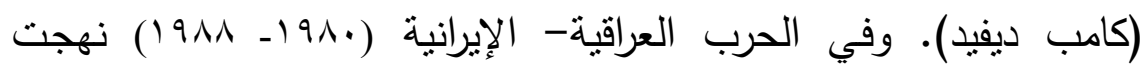

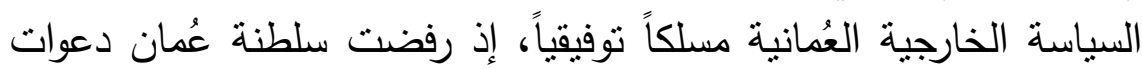

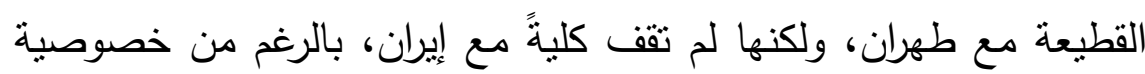

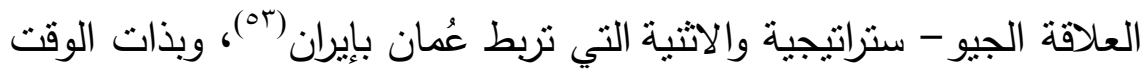

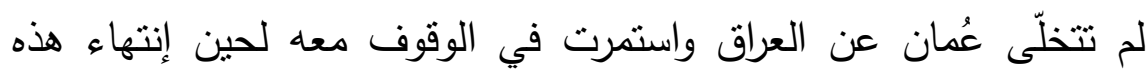
الحرب. وفي قضية دخول العراق إلى الكويت ظلت السلطنة تمارس سياسة التهات

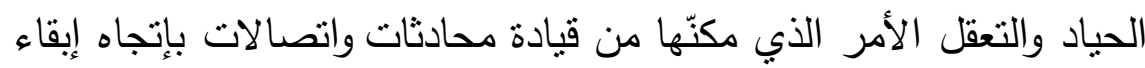

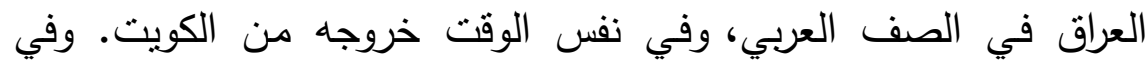

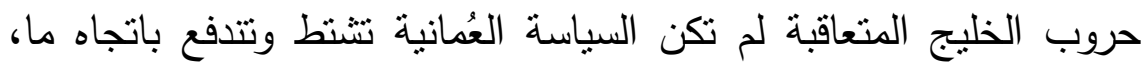

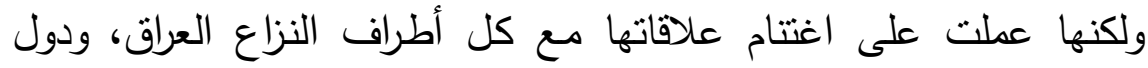

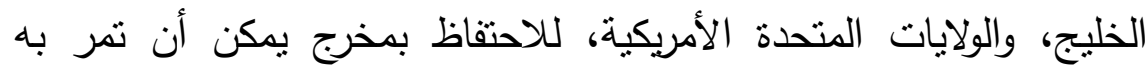

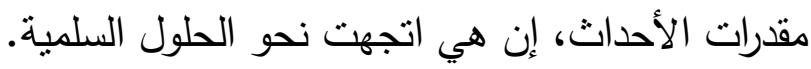
أ- طبيعة علاقات عُمان بباقي دول مجلس التعاون الخليجي 
تعد قضية واحات البريمي( (ن) التي تم حلها منذ منتصف خمسينات القرن

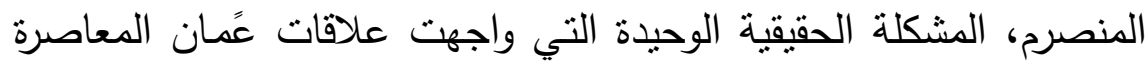

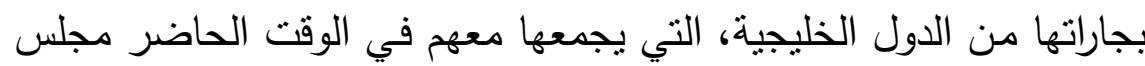

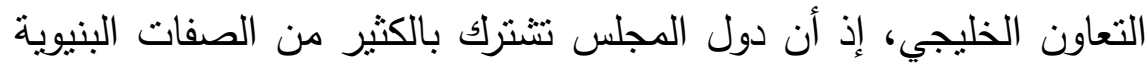

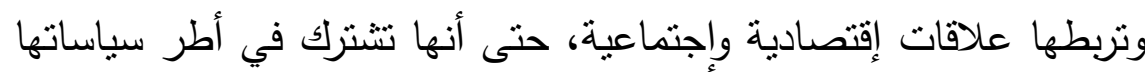

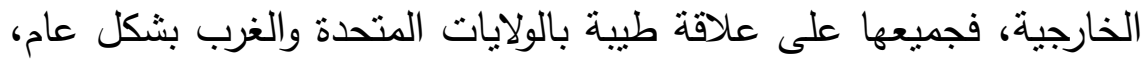
وتوجهاتها متشابهة بخصوص بعض القئه القضايا المهمة كفلسطين و (الإرهاب)،

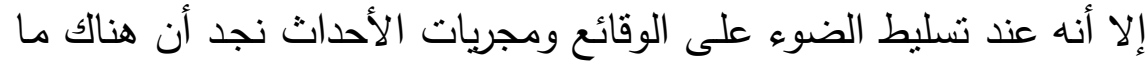

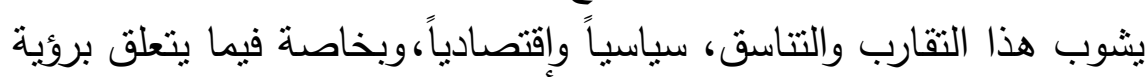
كل دولة من مجلس التعاون الخليجي حول العلاقة مع إيران، والتنافس بلانس

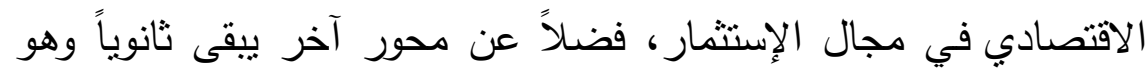

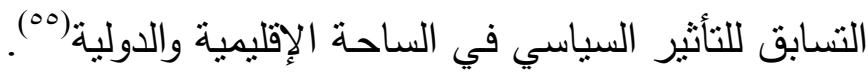

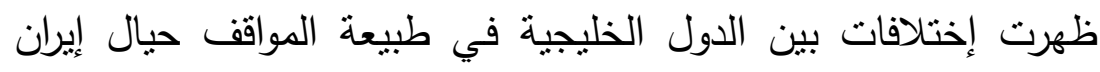

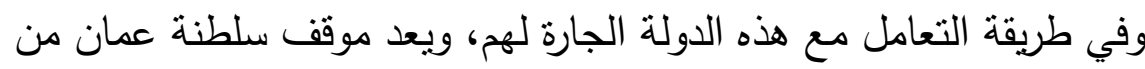

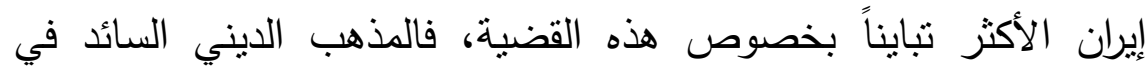

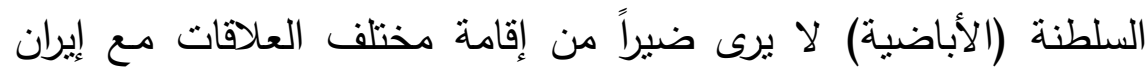

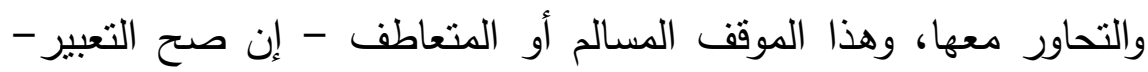

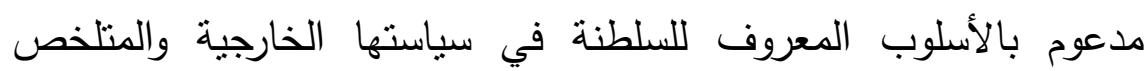

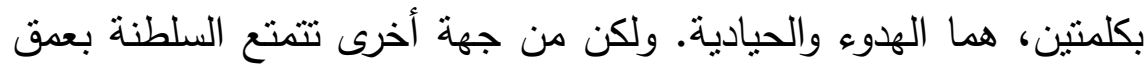

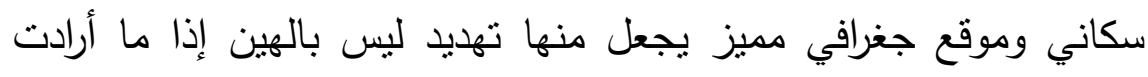

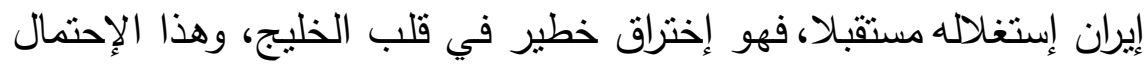

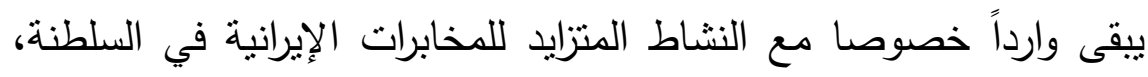

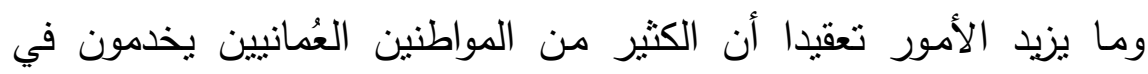

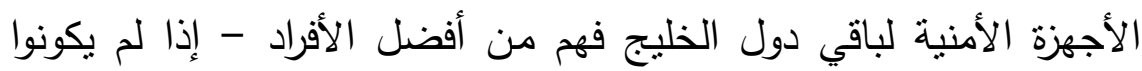


الأفضل- من ناحية الجهوزية والتدريب في المنطقة، ومجرد التفكير في إمكانية إختراقهم من قبل المخابرات الإيرانية تجعل منهم تهديد حقيقي (10). وفي مجال التتافس الإستثماري، تحاول معظم الدول الخليجية جلب أكبر

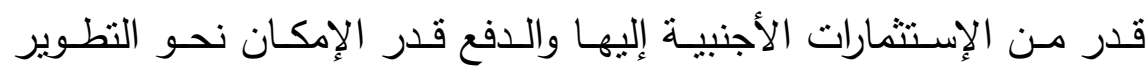

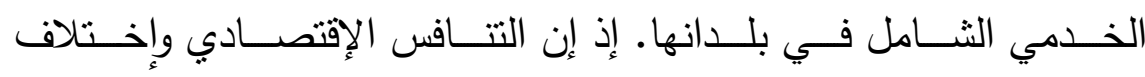

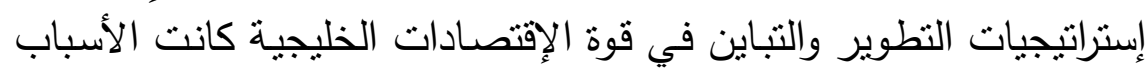

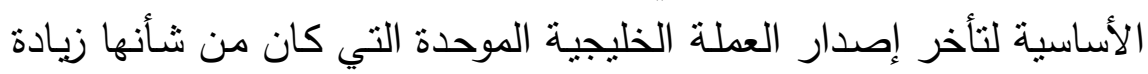

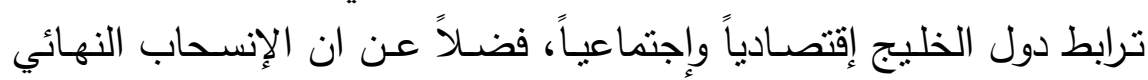

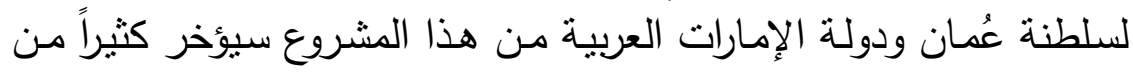
موعد تتفيذه، ويرى بعض المحللون بأن أسباب الإنسحاب من هذا هذا المشروع

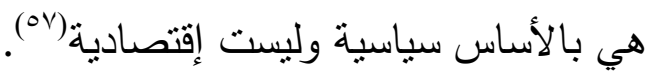

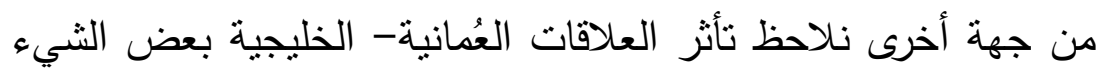

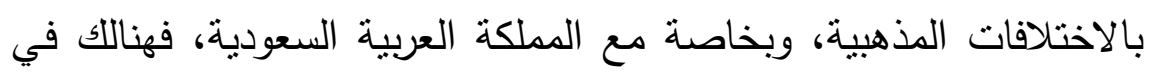
عُمان من يرى أن الخطاب والفكر الديني لاعاة الملكة العربية السعودية،

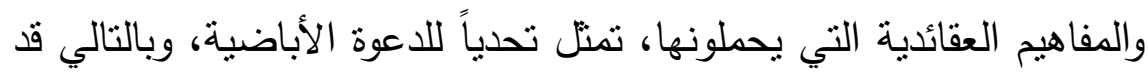

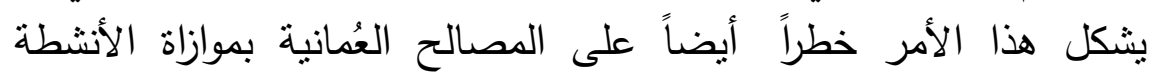
الإيرانية في المنطقة. فسلطنة عمان دولة مسلمة، ينتمي أغلب سكانها إلى الى الى الفران طائفة "الإباضية" الذين يقولون أنه على مدى السنوات الماضية حاولت الكثير من الثخصيات الدينية السعودية نشر الفكر السلفي في سلطنة عُمان، مما أثار حفيظة العُمانيين، ويوضح سعيد الهاشمي مدير البحوث في مجلس الدولة العُماني هذا الموقف بقوله "نحن لا نسمح للسعوديين

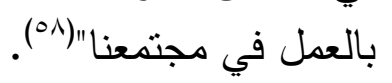


تتفرد عمان بعلاقات متميزة مـع إيران بخلاف باقي دول مجلس التعاون

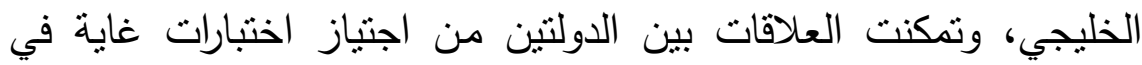

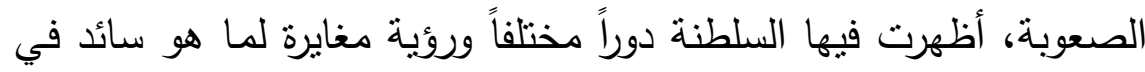
باقي دول مجلس التعاون الخليجي، وكانت قطر في السنوات الأخيرة تمانل إلى حد ما سياسة عُمان تجاه إيران، ولكن من منطلقات وأهداف سياسية

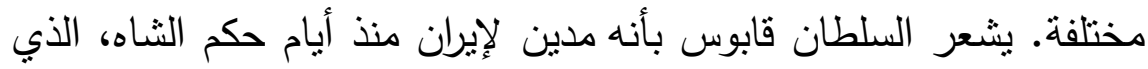
بادر في الاعتراف بشرعية الحكومة عندما تسلم السلطان قابوس السلطة لإنة عام •و9 ا. وكان لتذخل إيران العسكري المباشر الدور الحاسم في القضاء

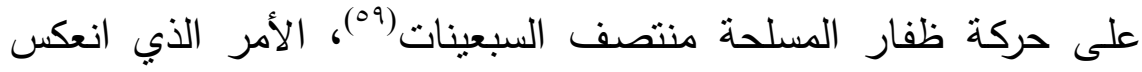
إيجابيا على العلاقة بين البلدين، وترجم في أكثر من طريقة، إذ أسس لثقة

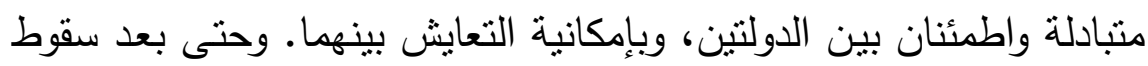

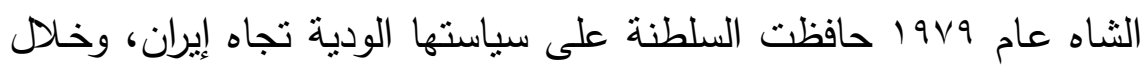

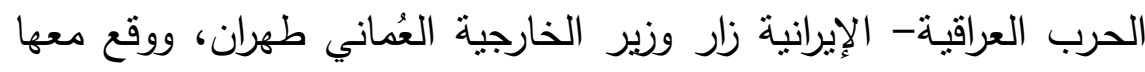
مسودة ثفاهم للتعاون السياسي والاقتصادي، وتحولت عُمان إلى قناة للحوار بين إيران وخصومها الخليجيين (·). وخلال العقود الأخيرة، تصاعدت المخاوف العالمية والإقليمية، وبخاصة

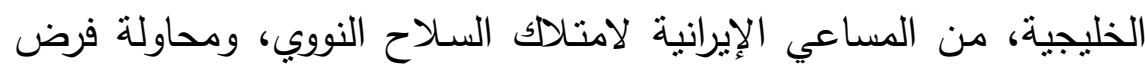

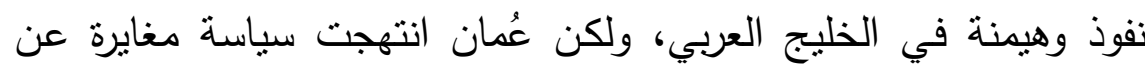
باقي دول مجلس التعاون في هذا الخصوص، إذ رفضت وهن رسمياً المشاركة في مشروع مظلة الدفاع الأميركية لحماية أمن الخليج، وتبنت طرون طرح اتفاقية التجارة الحرة بين دول مجلس التعاون وإيران، وابتعدت عن سياسة المحاور والاستقطاب، ونأت بنفسها عن كل أنكال المواجهات السياسية والإعلامية ولية مع إيران، والتزمت سياسة الهدوء. كما دعت إلى قيام تفاهم أميركي-

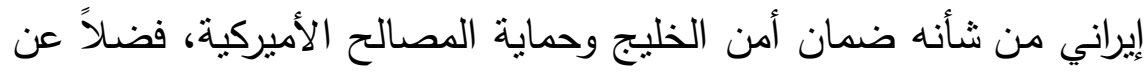
ترسيخ العلاقات بينها وبين إيران بزيارات على جميع المستويات (رؤساء 
الدول، لجان مشتركة، نوقيع اتفاقيات، تعاون عسكري) وهو ما أوجد حالة

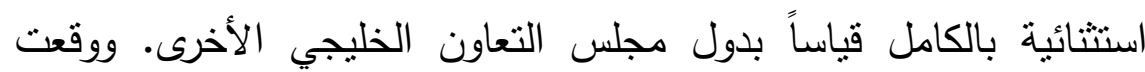

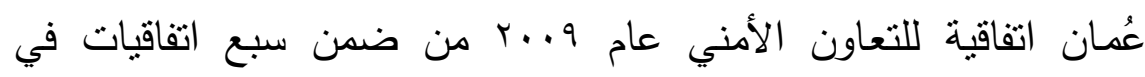
مجالات أخرى، واشتركت في مشروع إستثمار حقل غان فاز (كيش) الإيراني،

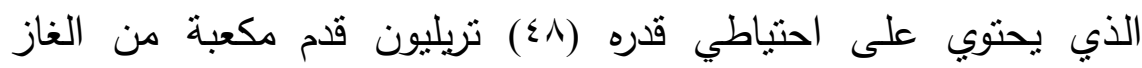
الطبيعي (") الطي تعد العلاقات الوثثقة بين إيران وعُمان، أحد الأسباب التي تقف وراء

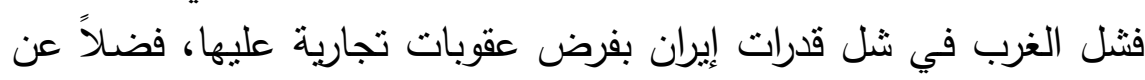

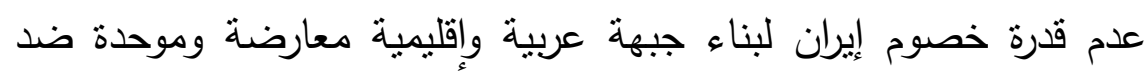

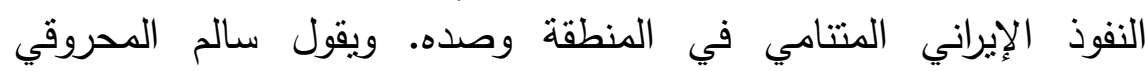

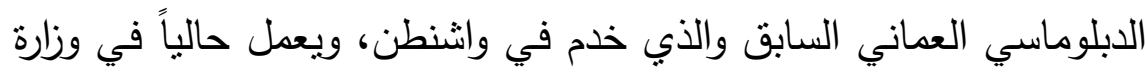

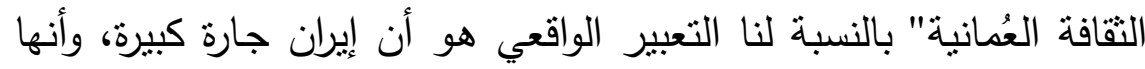

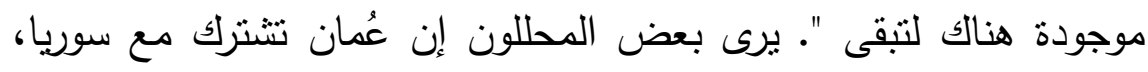
وقطر إلى حد ما، في النظر إلى إيران على إلى إنها حليفاً مهما، سياسياً

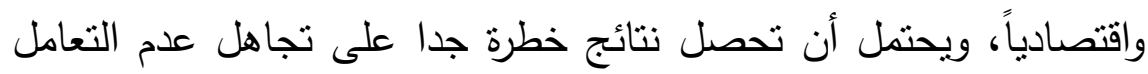

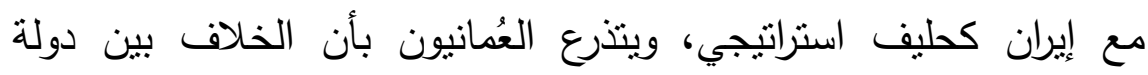

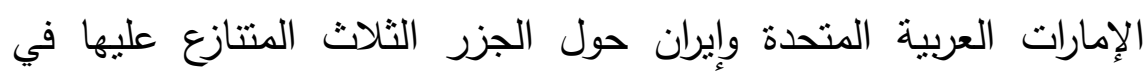

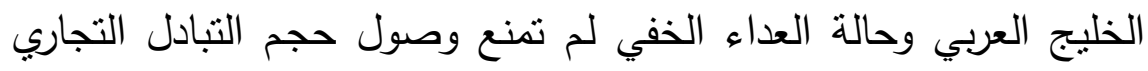

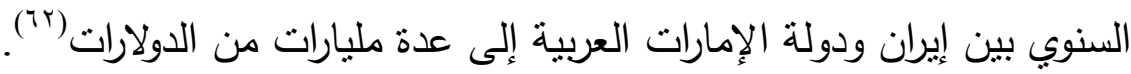

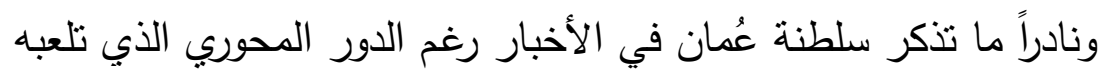

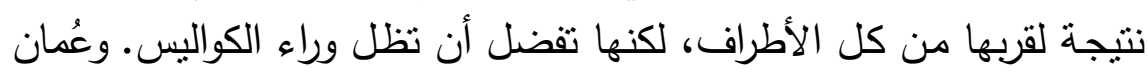

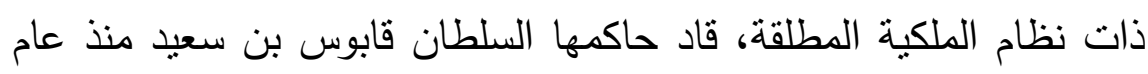

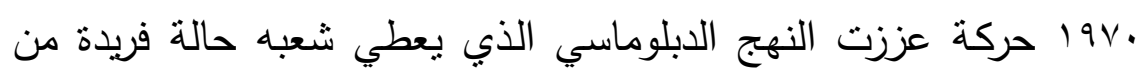

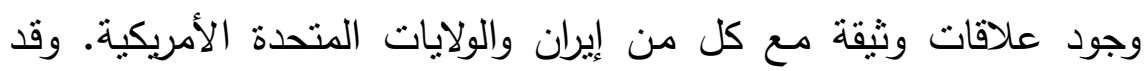

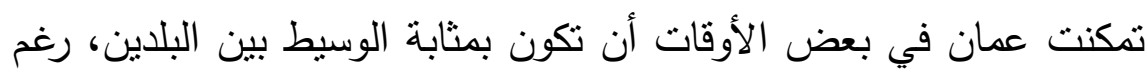


rVV]

حديث الكثيرين عن ترك الباب مفتوحا أمام احتمال أن تقوم الولايات المتحدة باستخدام القواعد العسكرية العمانية لانطلاق عملياتها في المنطقة

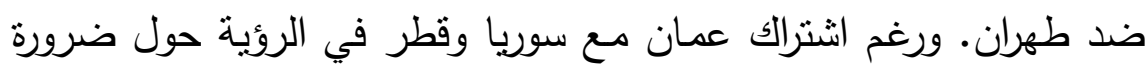

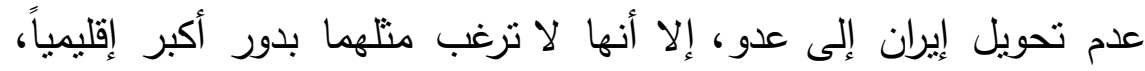

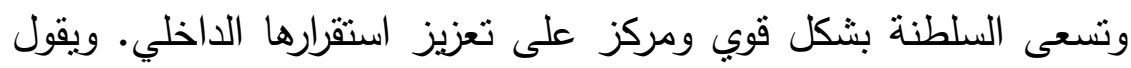

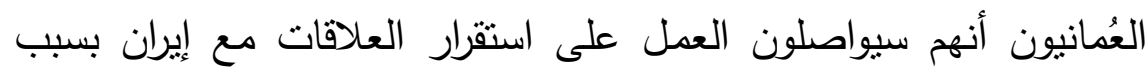

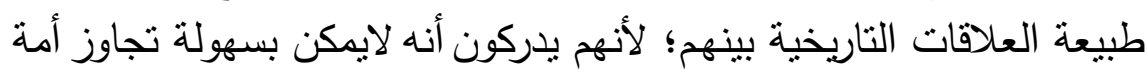

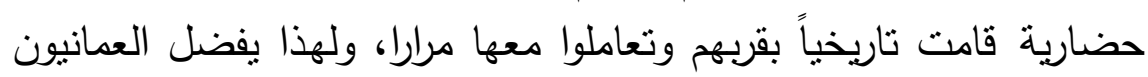

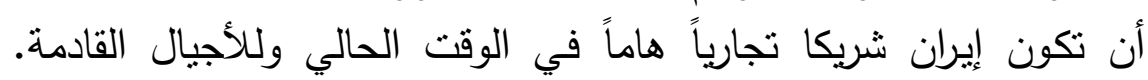

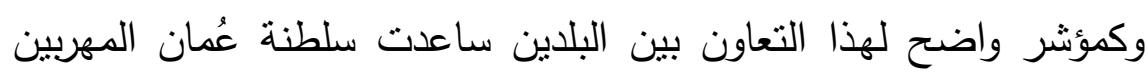

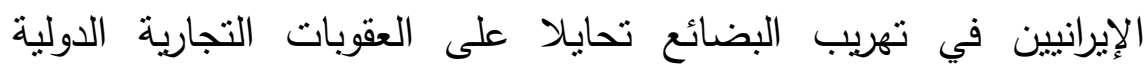

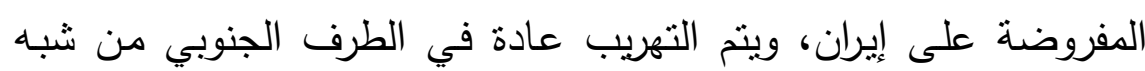

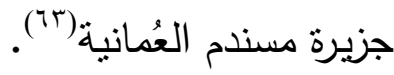

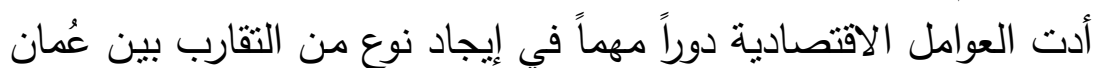

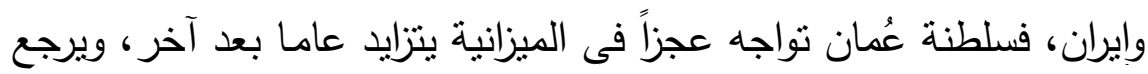

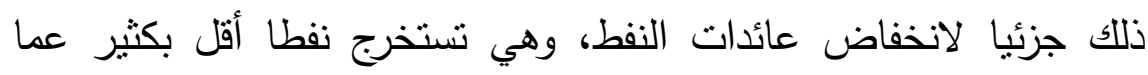

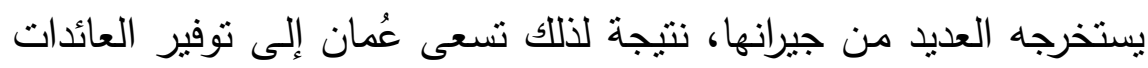

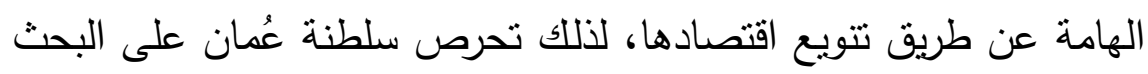

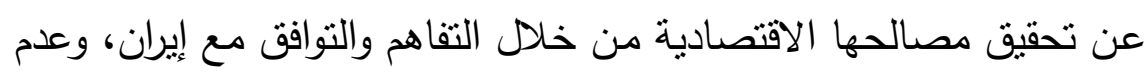

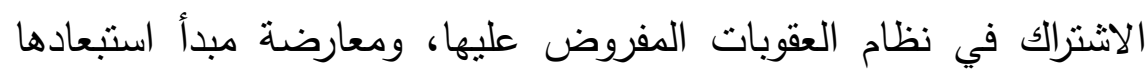

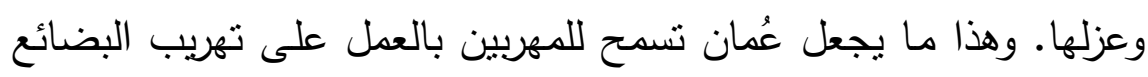

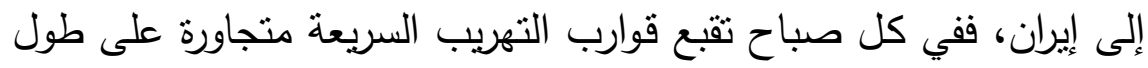

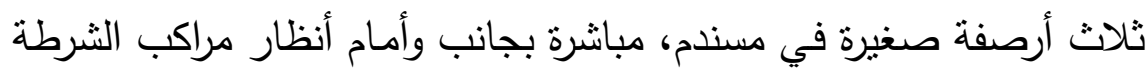

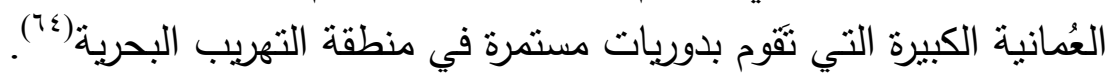


دو ( [rv^]

\section{ج- طبيعة العلاقات العُمانية- الأمريكية}

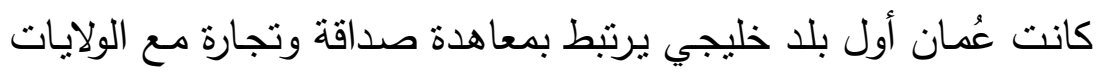

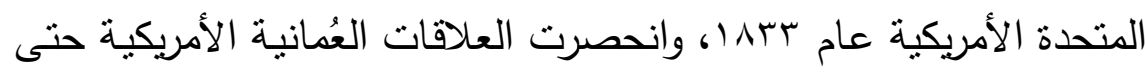

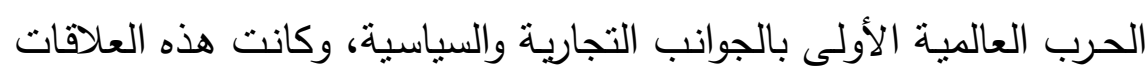

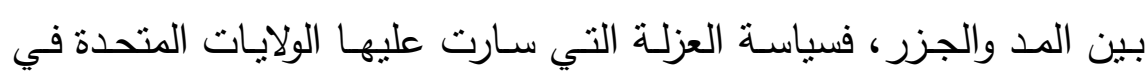

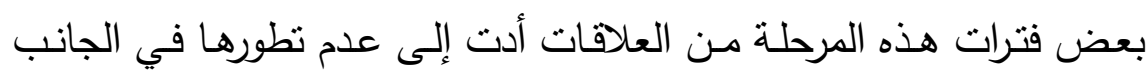

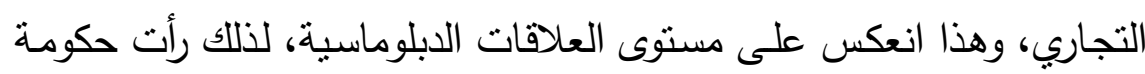
الولايات المتحدة إغلاق القنصلية في مسقط إبان تلك الحقبة. ومنذ الثلاثثينات

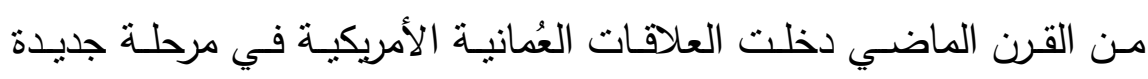

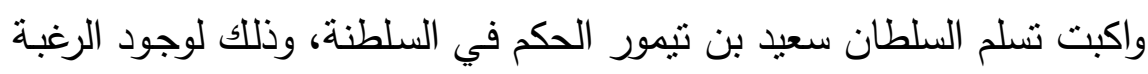

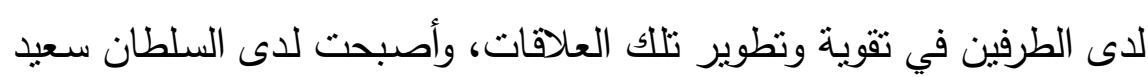

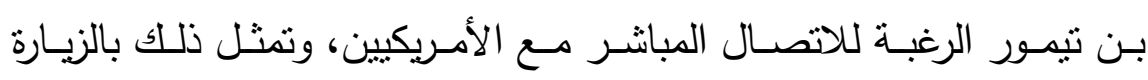

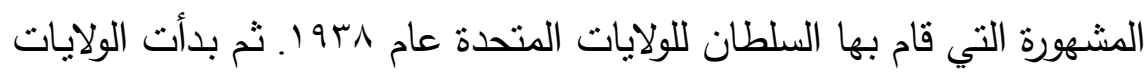

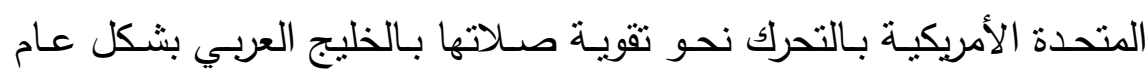

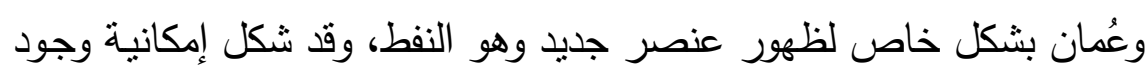

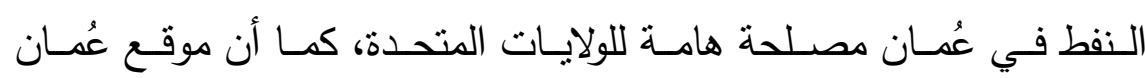

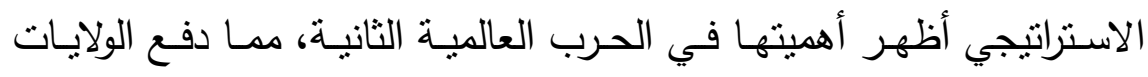

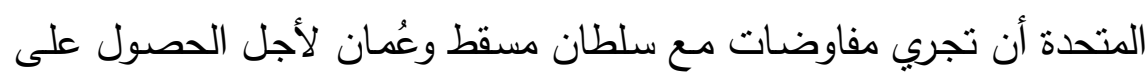

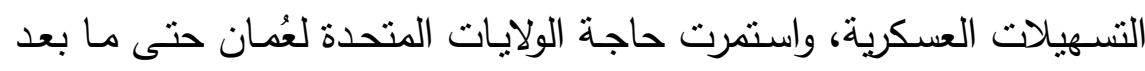

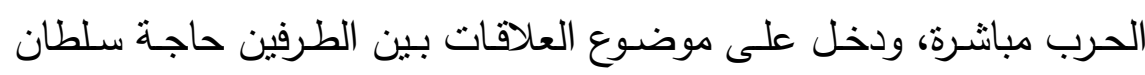


مسقط وعُمان للسلاح من أجل مواجهة المشكلات الداخلية في عُمان وكانت هذه الحاجة قد أعطت دفعة قوية لتتمية العلاقات بين الطرفين (10). ولم تكن بريطانيا، القوة الرئيسة المهيمنة على الخليج العربي وأقطاره

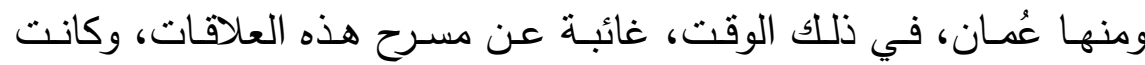

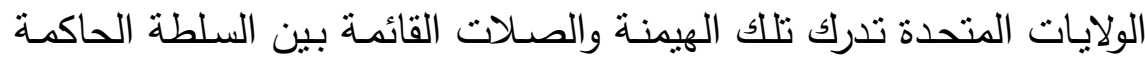

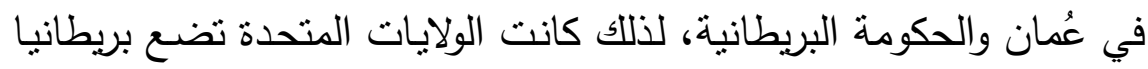

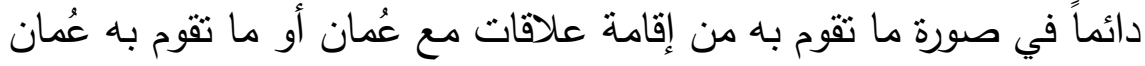

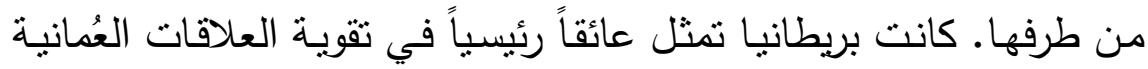

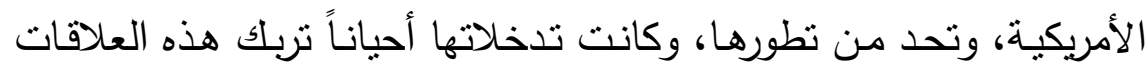

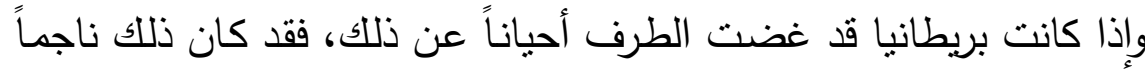

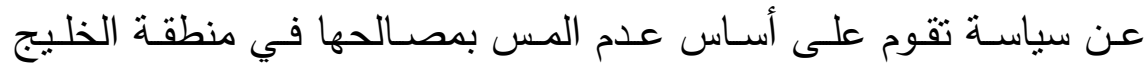
العربي التي كانت من وجهة نظرها تنظر إليه كوحدة واحدة، ولكن مجرى الكرى

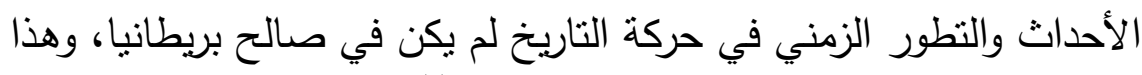

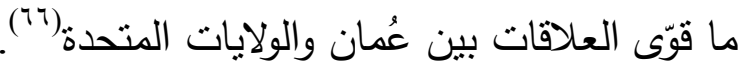

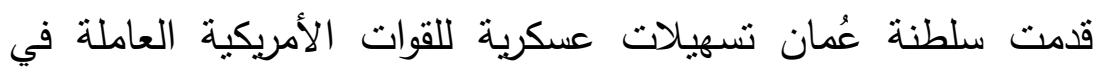

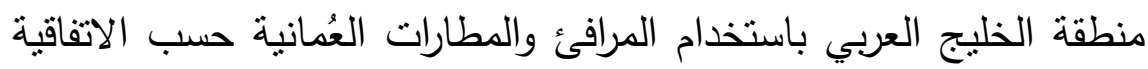

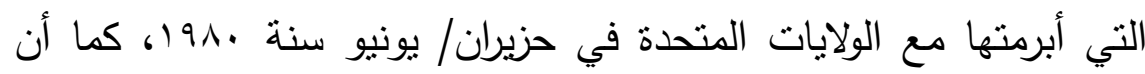
الاتفاقية أتاحت إقامة منشآت في جزيرة مصيرة والثمريات والسيب لاتيات لاستخدام

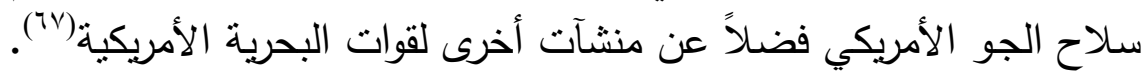

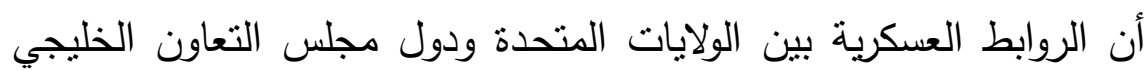

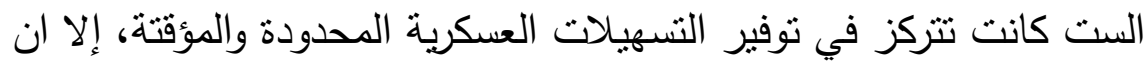

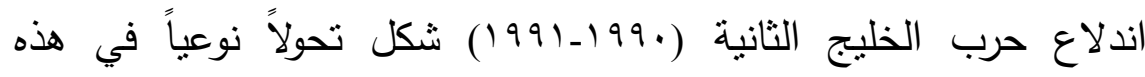
الروابط فتخلى الطرفان عن مفهوم الوجود العسكري "المستتر" وتم نشر نالئ

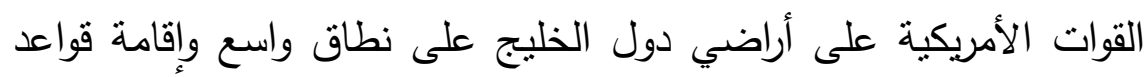




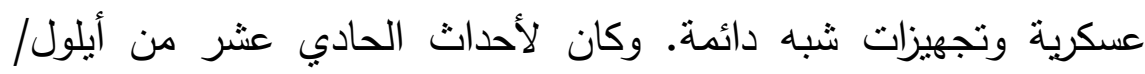

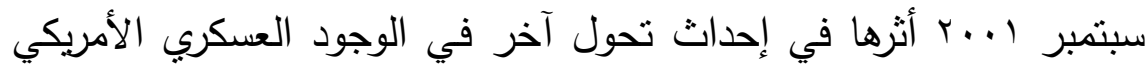

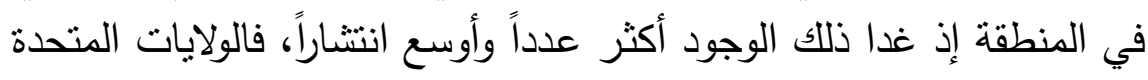

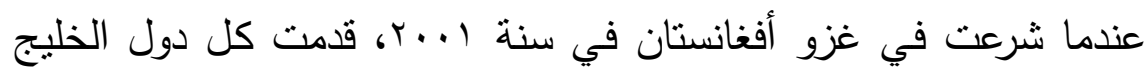

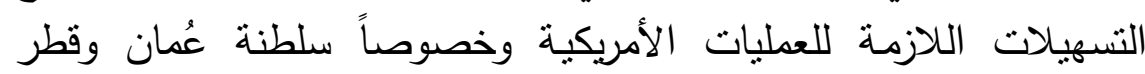

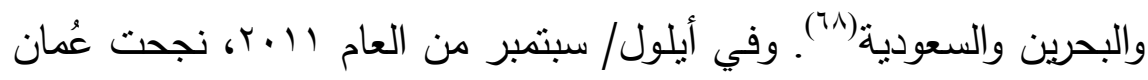

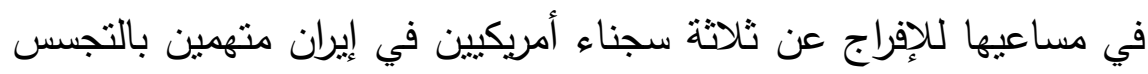

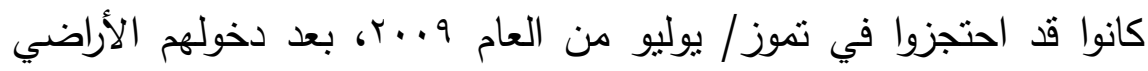

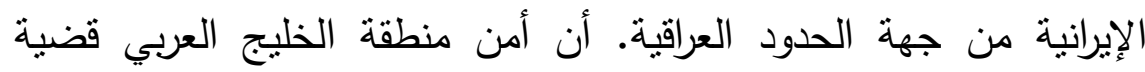

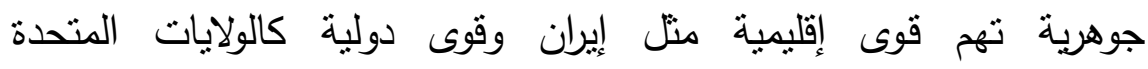

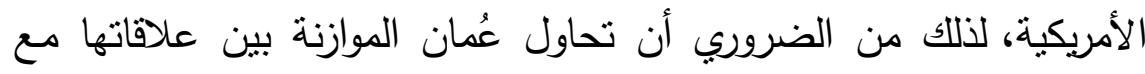

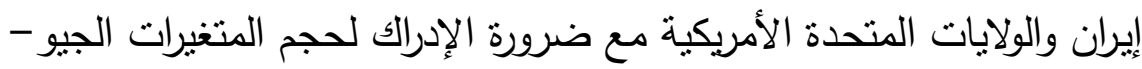

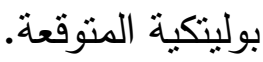

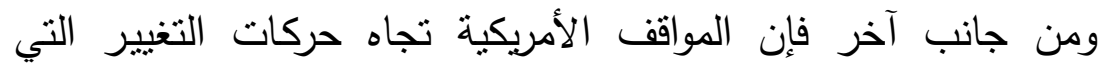

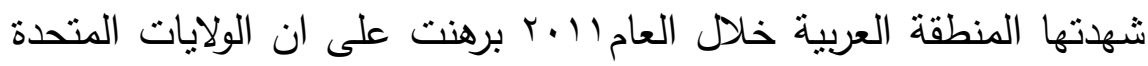

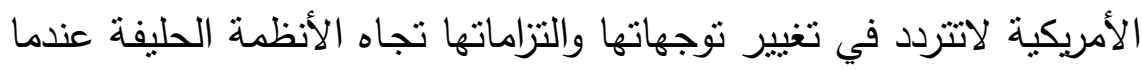

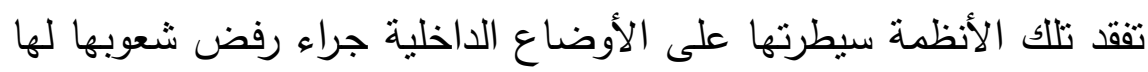

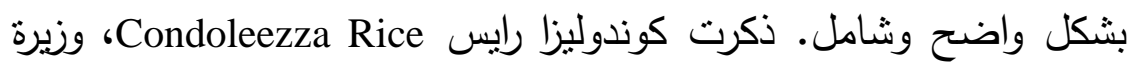
الخارجية الأميركية السابقة في خطاب ألقته في الجامعة الأميركية بالقاهرة

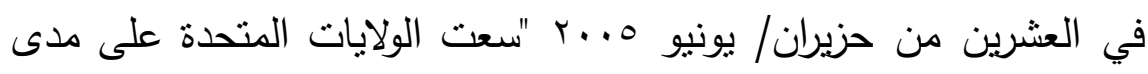

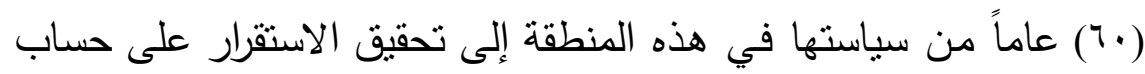

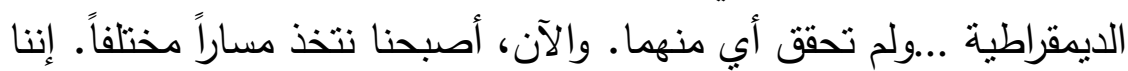
ندعم الطموح الديمقراطي لجميع الشعوب" (199". 
من خلال دراسة الظروف السياسية المعاصرة لسلطنة عُمان، سواء الداخلية منها، أو المحيطة بها إقليمياً وعالمياً، ومن خلال تفحص العوامل فله المؤثرة في هذه الظروف، التاريخية والإجتماعية والإقتصادية، تتبين لنا

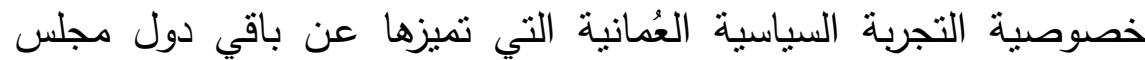
التعاون الخليجي، وان المعايير المشتركة التي يمكن من خلالها فهم وقياس الأوضاع في جميع الدول الخليجية قد لاتكون ملائمة للتطبيق في الحالة العُمانية. وان هذا التباين ناتج من الأرث التاريخي والسياسي والتقافي، فضلاً عن التتوع الفكري والاجتماعي الذي تتفرد بـه سلطنة عُمان عن باقي لاتي

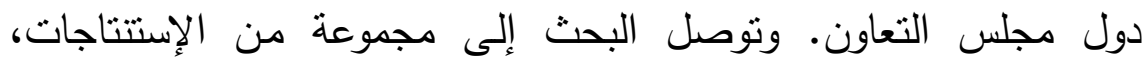

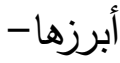

1- أدت الدعوة الأباضية دوراً مهماً في تشكيل التاريخ السياسي الحديث لسلطنة عُمان، ولازالت المضامين الفكرية لهذا المذهب تؤئز في توجهات السياسة العُمانية المعاصرة، المحلية والإقليمية.

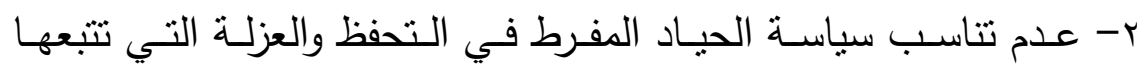
السلطنة في الوقت الحاضر وموقع عَمان الحالي في التفاعلات الإقليمية

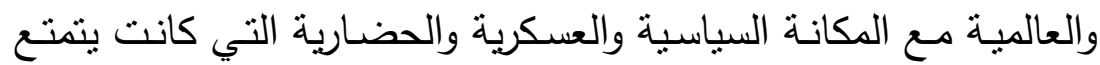
بها هذا البلد طوال القرنين الثامن عشر والتاسع عشر الميلاديين.

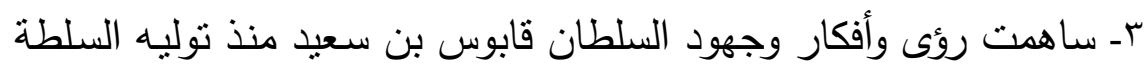

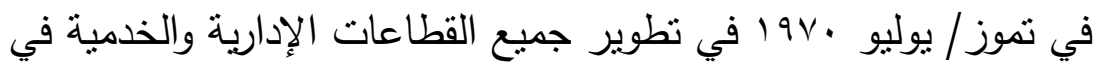

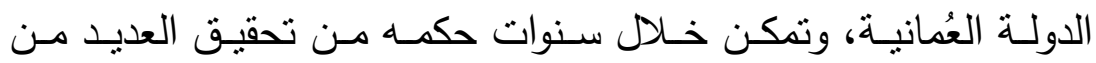
الانجازات للشعب العُماني. ع- يعد السلطان المركز الفعلي لصنع القرار في عُمـان، بـالرغم من وجود

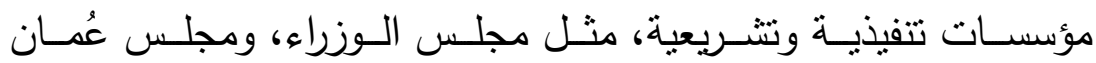
(البرلمان)، ولكن دورها محدوداً في صناعة القرار . 
0- هناللك عوامل داخلية توثر في عملية صنع القرار في سلطنة عُمان في

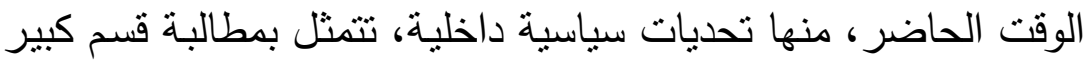

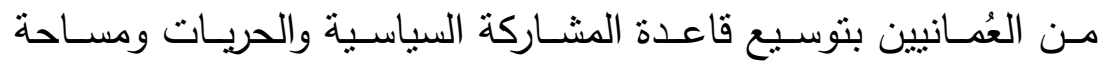
التعبير عن الرأي، وتحديات أخرى إقتصادية أبرزها إزدياد حجم البطالة مقابل إنخفاض عوائد النفط العُماني.

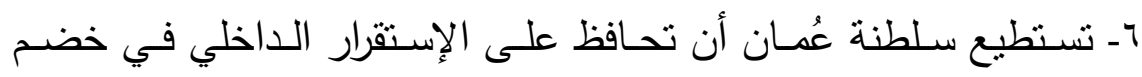

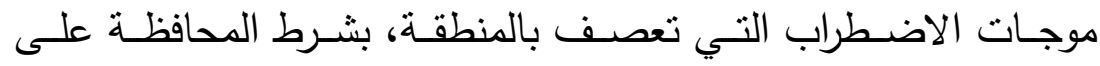

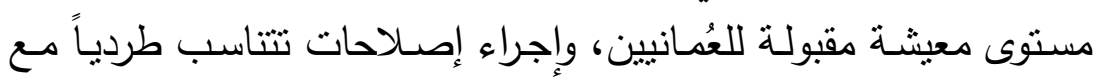

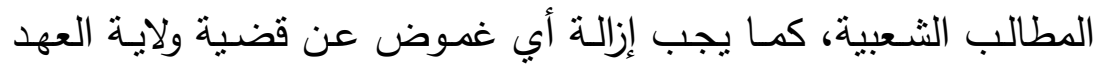
لضمان مستقبل هذا الإستقرار المنشود.

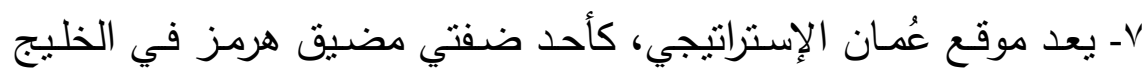

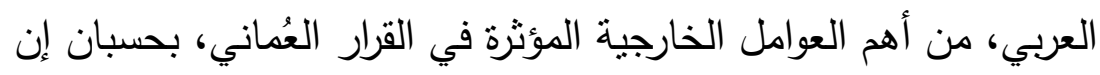

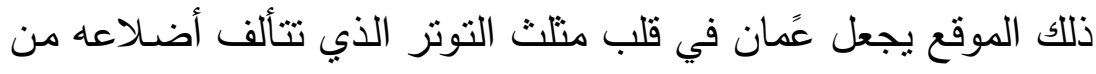
(الولايات المتحدة الأمريكية، إيران، دول مجلس التعاون الخليجي) - بعدي

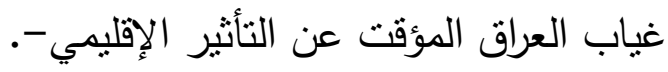

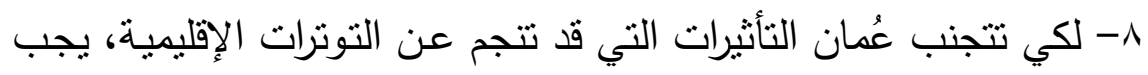
عليها ان توازن علاقاتها بإطراف التوتر بشكل دقيق بضاف إلى الحياد والتحفظ المعروف عن سياستها الخارجية. 


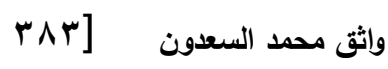

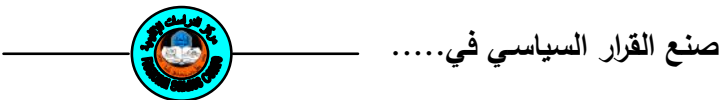

ملحق: نص النظام الأساسي للاولة في سلطنة عُمان (الاستور العُماني)

$$
\begin{aligned}
& \text { مرسوم سلطاني رقم } 1 \text { (1 / צ9 } 9 \\
& \text { بإصدار النظام الأساسي للاولة } \\
& \text { نحن قابوس بن سعيد سلطان عُمان }
\end{aligned}
$$

تأكيدا للمبادئ التي وجهت سياسة الدولة في مختلف المجالات خلال الحقبة

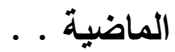

وتصميما على مواصلة الجهد من أجل بناء مستقبل أفضل يتميز بمزيد من المنجزات

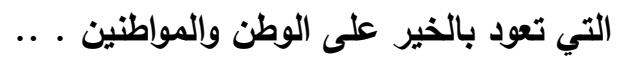

وتعزيزا للمكانة الدولية التي تحظى بها عُمان ودورها في إرساء دعائم السلام والأمن بأن والعدالة والتعاون بين مختلف الدول والشعوب. ويناء على ما تقتضيه المصلحة العامة

$$
\text { رسمنا بما هو آت }
$$

مادة (1) : إصدار النظام الأساسي للاولة بالصيغة المرافقة .

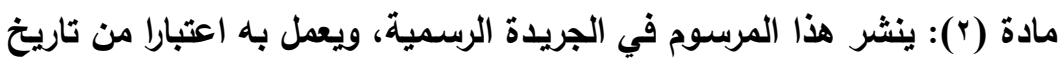

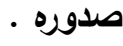

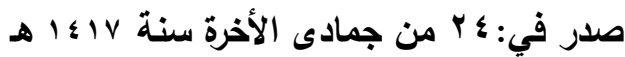

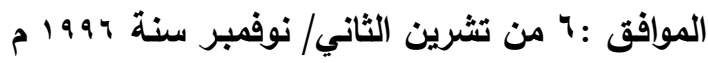


النظام الأساسي للاولة

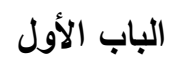

الاولة ونظام الحكم

مادة (1): سلطنة عُمان دولة عربية إسلامية مستقلة ذات سيادة تامة عاصمتها

$$
\text { مسقط. }
$$

$$
\text { مادة (ץ) ماد): دين الدولة الإسلام والثريعة الإسلامية هي أساس التشريع. }
$$

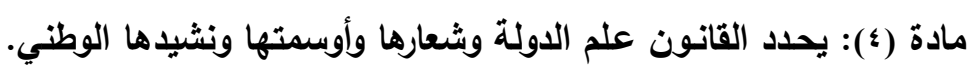

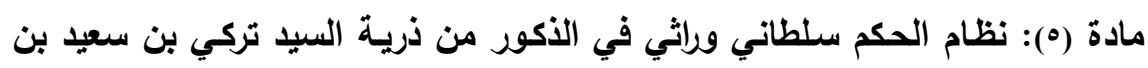

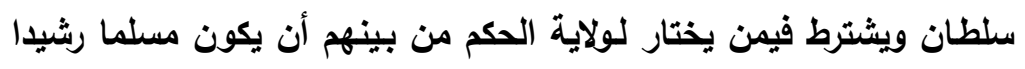

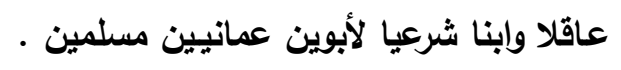

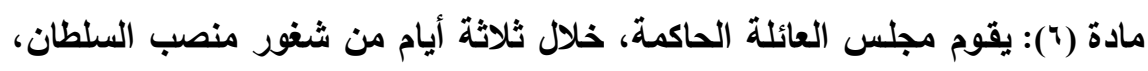

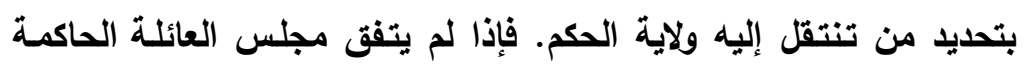
على اختيار سلطان للبلاد قام مجلس الدفاع بتثبيت من أشار بـه السلطان الدان

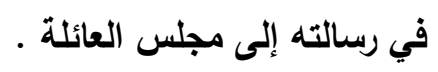

مادة (V): يؤدي السلطان قبل ممارسة صلاحياته، في جلسة مشتركة لمجلسي عُمـان

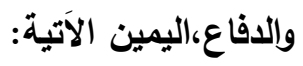




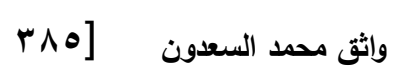

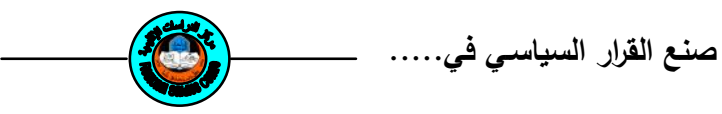

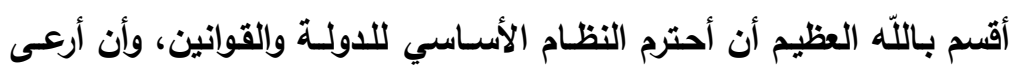

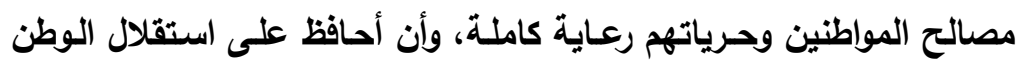
وسملامة أراضيه).

مادة (^): تستمر الحكومة في تسيير أعمالها كالمعتاد حتى يتم اختيار السلطان ويقوم بممارسة صلاحياته.

مـادة (9): يقـوم الحكم فـي السـلطنة على أسـاس العـلـ والثــورى والمســاواة . وللمواطنين - وفقا لهذا النظام الأساسي والثروط والأوضـاع التي يبينها

القانون - حق المشاركة في الثؤون العامة.

المبادئ الموجهة لسياسة الثاني

مادة (·) (1): المبادئ السياسية

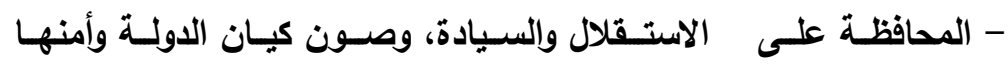
واستقرارها، والدفاع عنها ضد كل عدوان.

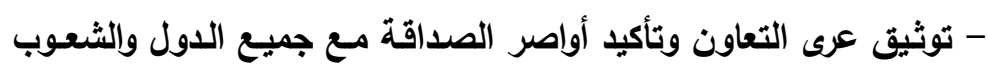

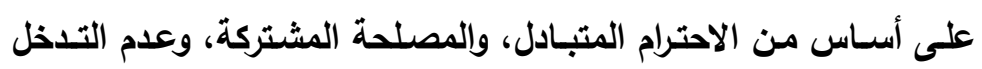

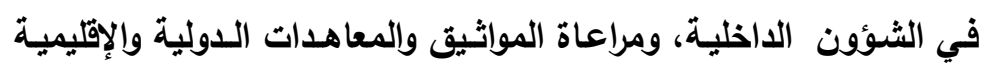

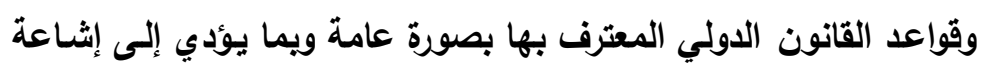

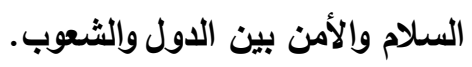

- إرسـاء أسس صسالحة لترسيخ دعائم شـورى صحيحة نـابعة مـن تـراث

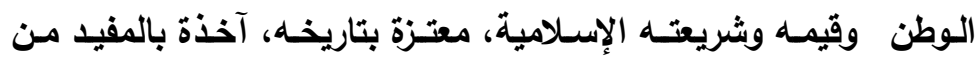

$$
\text { أساليب العصر وأدواته. }
$$

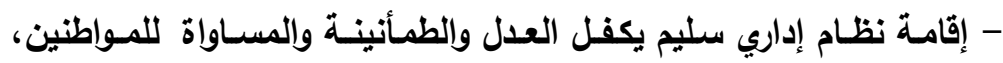
ويضمن الاحترام للنظام العام ورعاية المصالح العليا للوطن. 


\section{مادة (11): المبادئ الاقتصادية}

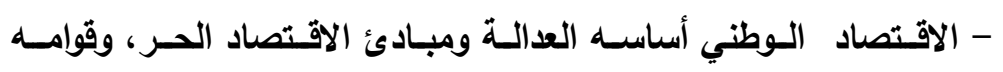

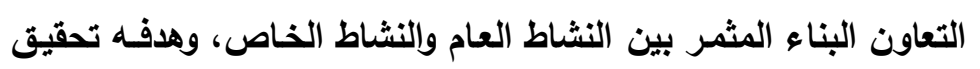

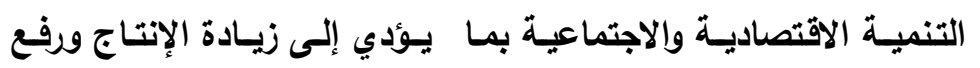

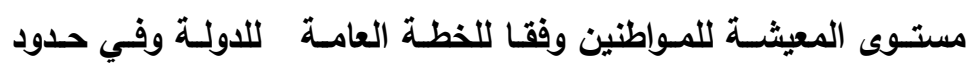
القانون. - حرية النشاط الاقتصادي مكفولة في حدود القانون والصالح العام ويما

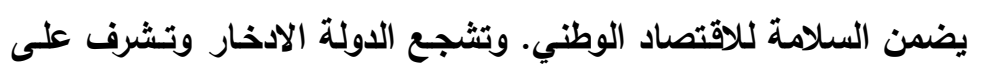
تنظيم الائتمان. - الثروات الطبيعية جميعها ومواردها كافة ملك للدولة، تقوم على حفظها

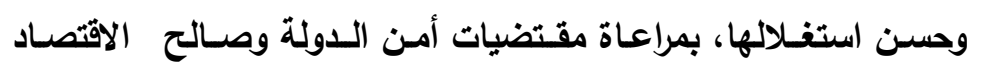

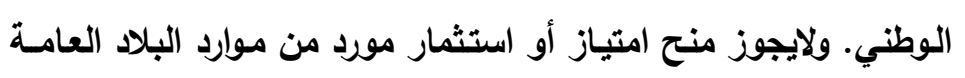
الا بموجب قانون ولفترة زمنية محددة، ويما يحفظ المصالح الوطنية.

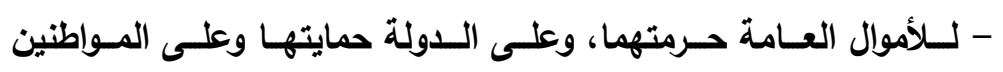
والمقيمين المحافظة عليها.

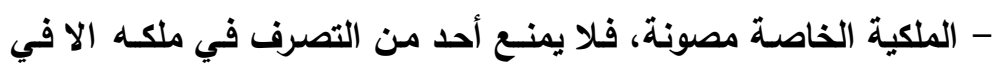

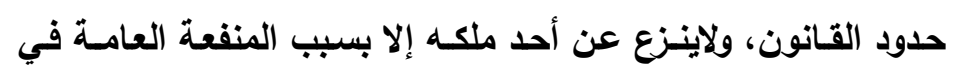

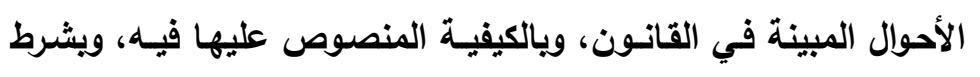

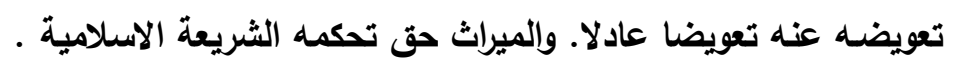

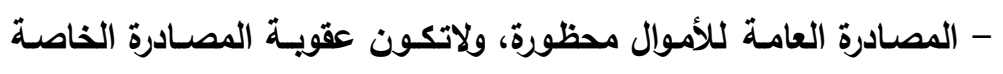
إلا بحكم قضائي في الأحوال المبينة بالقانون.

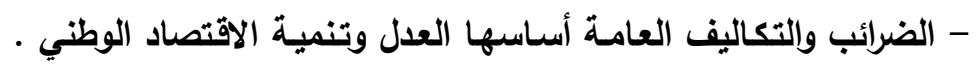


- إنشاء الضرائب العامة وتعديلها والغاؤها لايكون إلا بقانون ولايعفى أحد من أدائها كلها أو بعضها إلا في الأحوال المبينة في القانون. ولايجوز

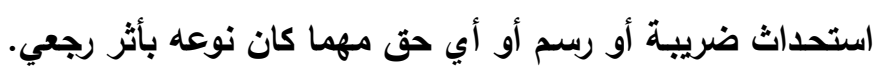
مادة (r ا ): المبادئ الاجتماعية

-العدل والمساواة وتكافؤ الفرص بين العمانيين دعامات للمجتمع تكفلها الدولة.

- التعاضد والتراحم صلة وثيقة بين المواطنين، وتعزيز الوحدة الوطنيـة

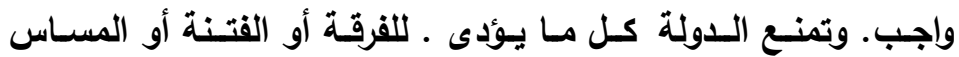
بالوحدة الوطنية. - الأسرة أساس المجتمع، وينظم القانون وسائل حمايتها، والحفاظ على

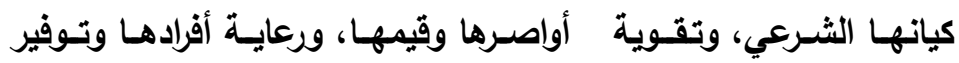
الظروف المناسبة لتنمية ملكاتهم وقدراتهم.

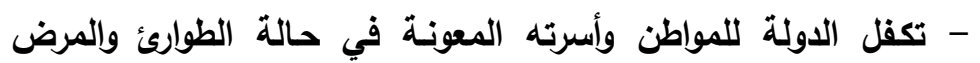

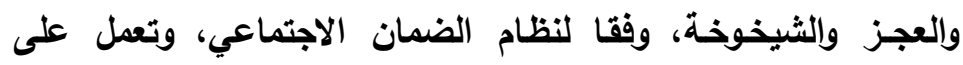
تضامن المجتمع في تحمل الأعباء الناجمة عن الكوارث والمحن العامة .

- تعنى الدولـة بالصحة العامـة ويوسـائل الوقايـة والعلاج من الأمراض

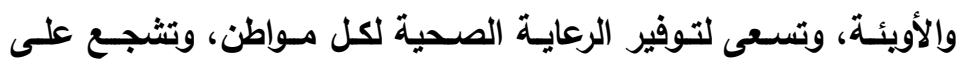

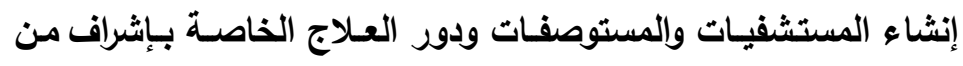
الدولة ووفقا للقواعد التي يحددها القانون. كما تعدل على المحافظة

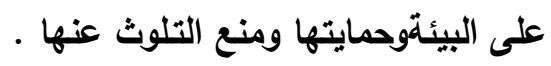

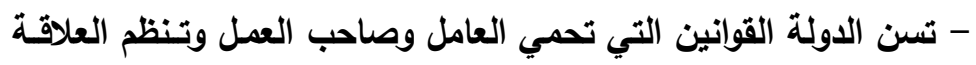

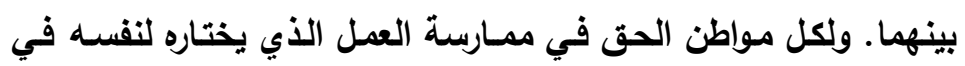


حدود القانون · ولايجوز فرض أي عمل اجباري على أحد إلا بمقتضى قانون ولأداء خدمة عامة ويمقابل أجر عادل

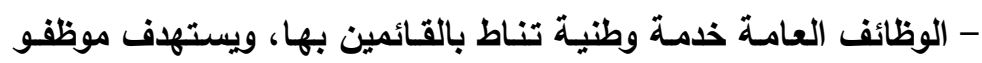

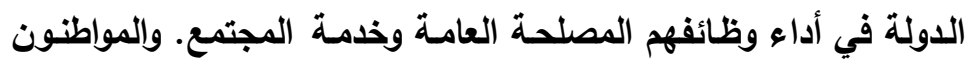
متساوون في تولي الوظائف العامة وفقا للشروط التي يقررها القانون. - التعليم ركن أساسي لتقلم المجتمع ترعاه الدولة وتسعى لنشره وتعميمه. - يهاف التعليم الى رفع المستوى الثقافي العام وتظويره وتنمية التفكير العلمي، وإذكاء روح البحث، وتلبية منطلبات الخطط الاقتصادية والاجتماعية، وايجاد جيل قوي في بنيته وأخلاقه، يعتز بأمته ووطنه

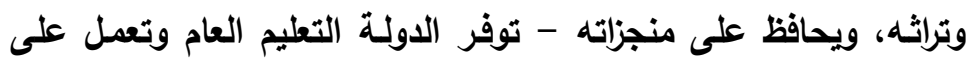

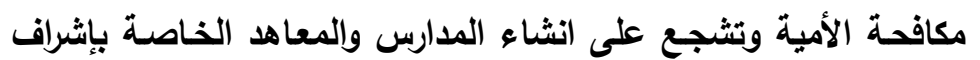
من الدولة ووفقا لأحكام القانون. - تـرعى الدولـة التراث الوطنـي وتحافظ عليـه، وتشجـع العلوم والفنـون والآداب والبحوث العلمية وتساعدعلى نشرها. مادة (ع )): المبادى \& الأمنية - السـلام هدف الدولـة، وسـلامة الـوطن أمسانة في عنق كل مـواطن .

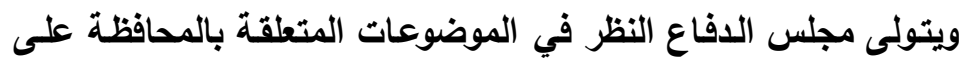
سلامة السلطنة والدفاع عنها

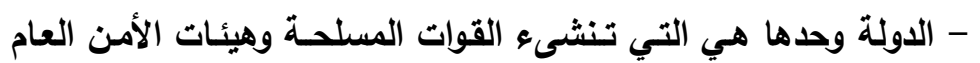

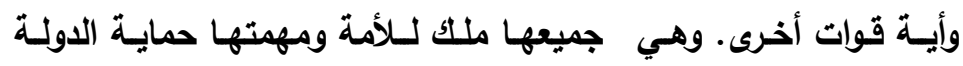

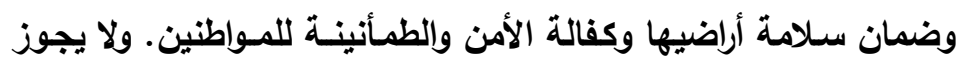

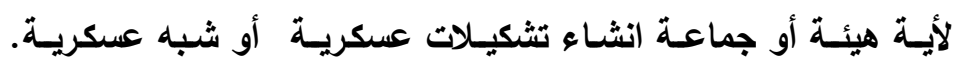


وينظم القانون الخدمـة العسكريـة، والتعبئة العـامة أو الجزئيـة، وحقوق

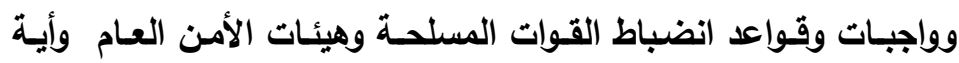

قوات أخرى تقرر الدولة انشاءها.

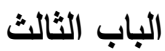

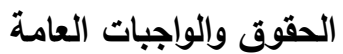

مـادة (ه) : الجنسـية ينظمها القانـون، ولايجـوز اسـاطها أو سـبها إلا في حدود القانون

مادة (1 1): لايجوز ابعاد المواطنين أو نفيهم أو منعهم من العودة الى السلطنة.

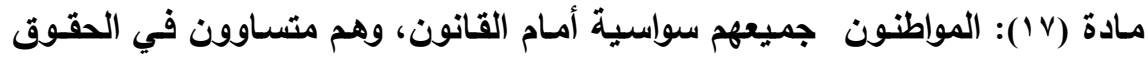

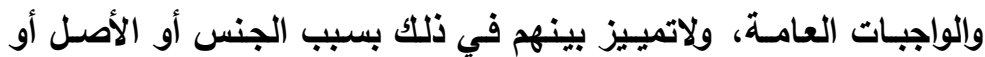

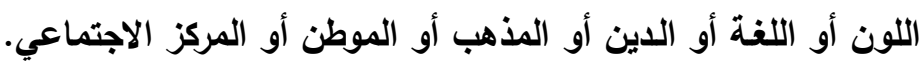

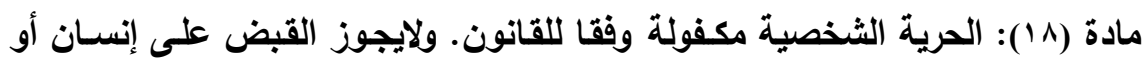
تفتيثـه أو حجزه أو حبسـه أو تحديد إقامتهـ أو تقييد حريته في الاقامـة

$$
\text { أو التنقل إلا وفق أحكام القانون. }
$$

مادة (9)): لايجوز الحجز أو الحبس في غير الأمساكن المخصصة لذلك في قوانين

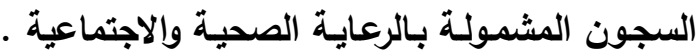

مادة (·r): لايعرض أي انسـان للتعذيب المـادي أو المعنوي أو للاغراء، أو للمعاملـة الحاطة بالكرامة. ويحدد القانون عقاب من يفعل ذلك. كما يبطل كل قول أو اعتراف يشبت صدوره تحت وطأة التعذيب أو بـالاغراء أو لتلك المعاملة

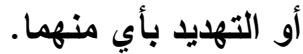
مادة (1)): لاجريمـة ولاعقويـة إلا بناء على قانون، ولاعقاب إلا على الأفعـال الـلاحقة للعمل بالقانون الذي ينص عليها. والعقوية شخصية. 
د (

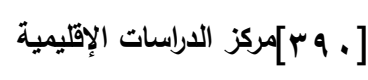

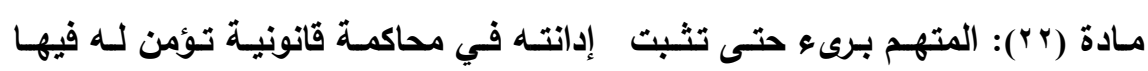

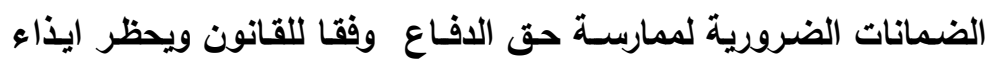
المتهم جسمانيا أو معنويا.

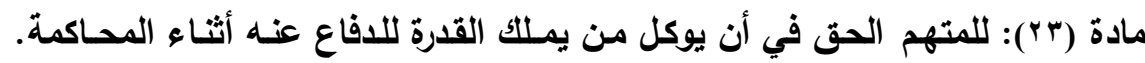
ويبين القانون الأحوال التي يتعين فيها حضور محام عن المتهم ويكفل

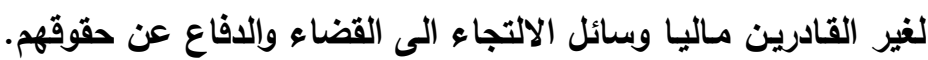
مادة (צ r): يبلغ كل من يقبض عليه أو يعتقل بأسباب القبض عليه أو اعتقاله فورا،

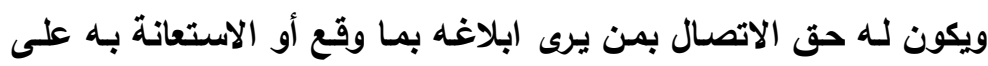

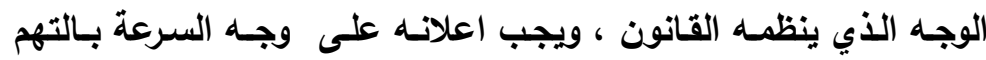

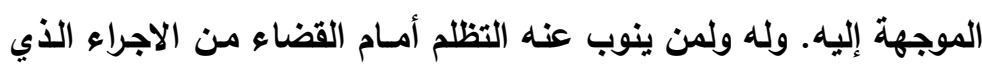

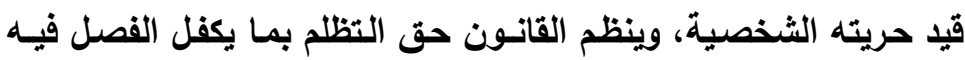
خلال مدة محدةة، وإلا وجب الافراج حتما.

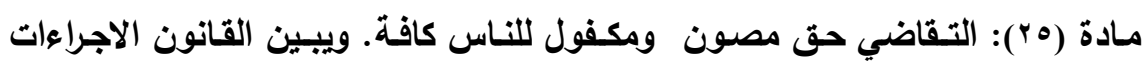

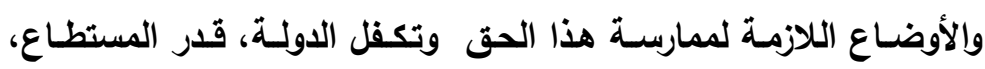
تقريب جهات القضاء من المتقاضين وسرعة الفصل في القضايا.

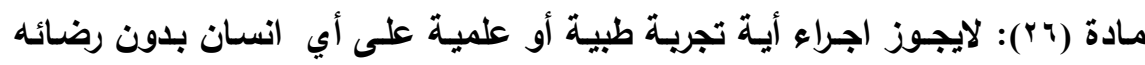
الحر.

مادة (Yr): للمسـاكن حرمسة، فلا يجوز دخولها بغير اذن أهلها، إلا في الأحوال التي يعينها القانون ويالكيفية المنصوص عليها فيه.

مادة (ץ^): حريـة القيام بالثعائر الاينية طبقا للعادات المرعية مصونة على على ألا يخل

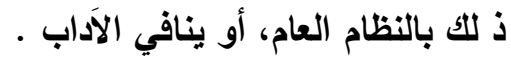

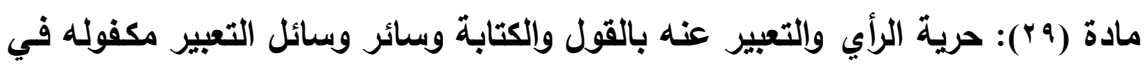
حدود القانون. 
مادة (·•): حريـة المراسلات البريدية والبرقية وإلمخاطبات الهاتفية وغيرها من وسـائل

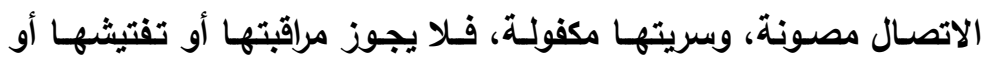

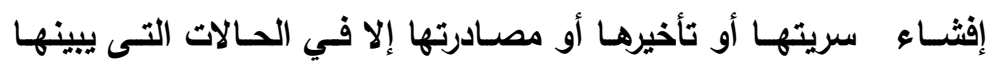
القانون ويالاجراءات المنصوص عليها فيه .

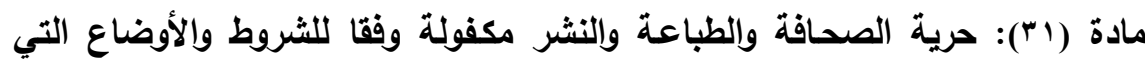
يبينها القانون. ويحظر مـايؤدى الى الفتنة أو يمس بأمن الدولـة أو والو يسيء الى كرامـة الانسـان و حقوقه. مادة (rץ): للمواطنين حق الاجتماع ضمن حدود القانون.

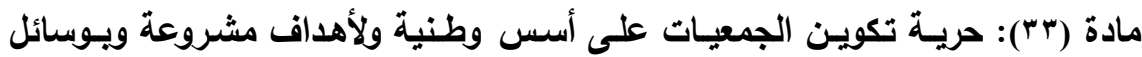

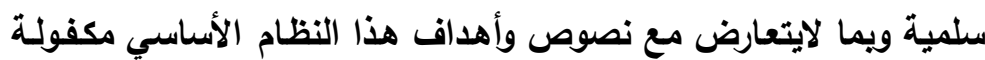
وفقا للشروط والأوضاع التي يبينها القانون. ويحظر إنشاء جمعيات يكون لصناع

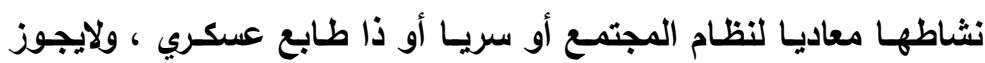
اجبار أحد على الانضمام الى أيـة جمعية. مـادة (๕): للمواطنين الحق في مخاطبة السلطات العامـة فيمـا ينويهم من أمسور

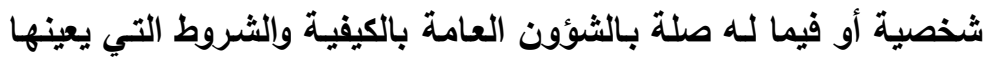

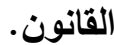

مادة (ro): يتمتـع كل أجنبي موجـود في السلطنـة بصفة قانونية بحمايـة شخصـه وأملاكـه طبقـا للقــانون. وعليـه مـراعاة قيم المجتمـع واحتـرام تـقاليده

$$
\text { ومشاعره. }
$$

مادة (ه־): تسليم اللاجئين السياسيين محظور، وتحدد القوانين والاتفاقيات الدولية

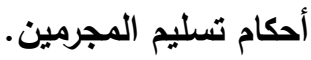

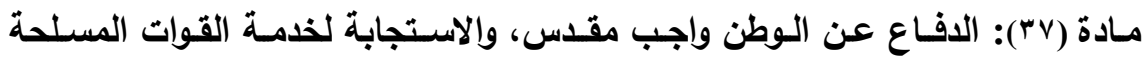
شرف للمواطنين ينظمه القانون. مادة (^^): الحفاظ على الوحدة الوطنية وصيانة أسرار الدولة واجب على كل مواطن. 
مادة (ب) أداء الضرائب وإلتكاليف العامة واجب وفقا للقانون.

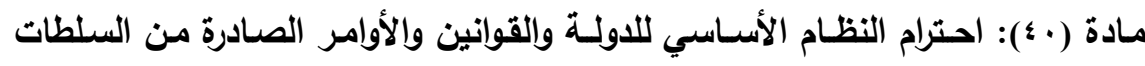

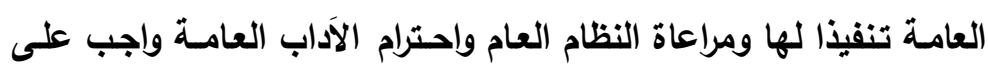

\section{جميع سكان السلطنة.}

$$
\text { رأباب الرابعة }
$$

مـادة (1)): السـلطان رئيس الدولــة والقائد الأعلى للقوات المسلحة، ذاتـه مصونـة

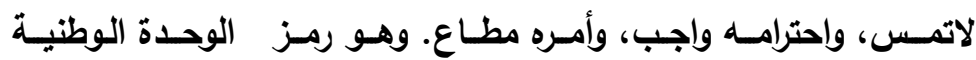

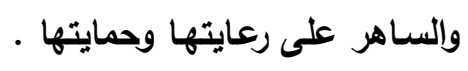

مادة (r \&) : يقوم السلطان بالمهام التالية

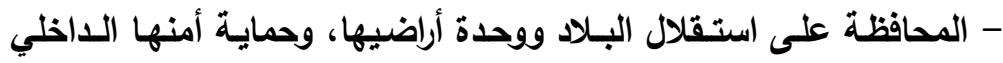

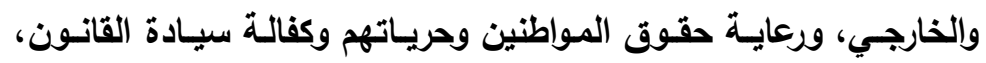

$$
\text { وتوجيه السياسة العامة للاولة. }
$$

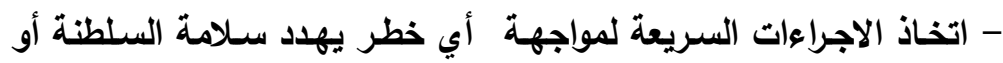

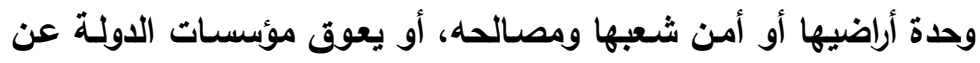

$$
\text { اداء مهامها. }
$$

- تمثيل الدولة في الاخلل وتجاه الدول الأخرى في جميع العلاقات الدولية. - رئاسة مجلس الوزراء أو تعيين من يتولى رئاسته. - رئاسة المجالس المتخصصة أو تعيين من يتولى رئاستها. - تعيين نواب رئيس مجلس الوزراء والكوزراء ومن في حكمهم واعفائهم من مناصبهم . من - تعيين وكلاء الوزارات والأمنـاء العامين ومن في حكمهم واعفائهم من مناصبهم. - تعيين كبار القضاة واعفائهم من مناصبهم. 


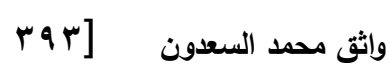

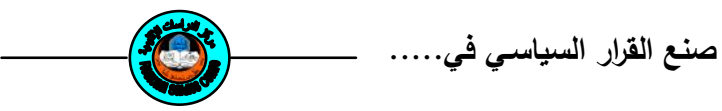

- اعلان حـالة الطوارى و التعبئـة العامـة وإلحرب وعقد الصـلح ويبين القانون أحكام ذلك. - اصدار القوانين والتصديق عليها.

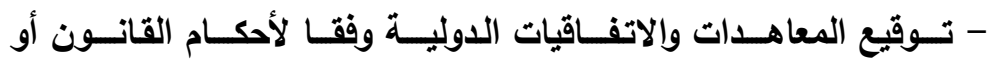
التفويض في توقيعها واصدار مراسيم التصديق عليها.

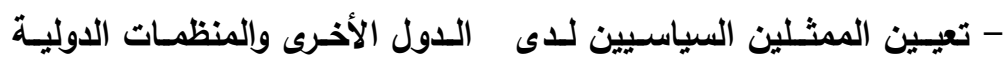

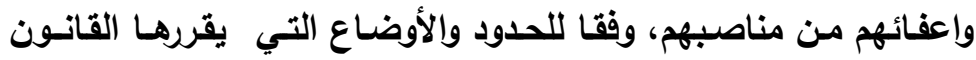
وقبول اعتماد ممثلي الدول والمنظمات الدولية لايه. - العفو عن أية عقوية أو تخفيفها. - منح أوسمة الثرف والرتب العسكرية. مادة (43): يعاون السلطان في رسم السياسة العامة للاولية وتـفيذها مجلس للوزراء ومجالس متخصصة.

\section{مجلس الوزراء}

مـادة (ء ؛): مجلس الـوزلاء هو الهيئة المنوط بهـا تـنفيذ السياسـات العامـة للاولـة ويتولى بوجه خاص مايلي:

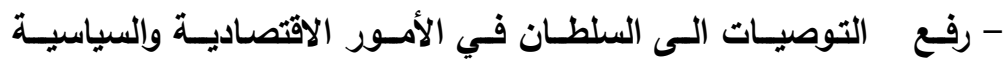

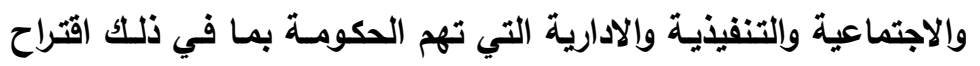
مشروعات القوانين والمراسيم. - رعاية مصالح المواطنين وضمان تـوفير الخدمـات الضرورية لهم ورفع مستوالهم الاقتصادي والاجتماعي والصحي والثقافي. 
د ( [ 9 [ب[مركز الدراسات الإقليمية

- تحديــ الأهداف والسيـاسات العـامة للتنميـة الاقتصاديـة والاجتماعيـة والاداريـة وإقتراح الوسـائل والاجراءات اللازمة لتنفيذها والتي تكفل حسن التهات استخدام الموارد المالية والاقتصادية والبشرية.

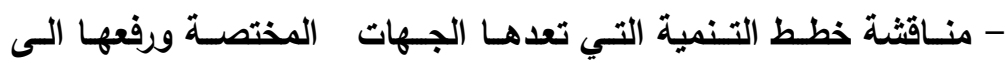
السلطان للاعتماد، ومتابعة تنفيذها. - مناقشة اقتراحات الوزارات في مجال تنفيذ اختصاصاتها واتخاذ التوصيات والقرارات المناسبة في شأنها.

- الإشـراف على سـير الجـهاز الإداري للاوبــة ومتابعـة أدائـه لواجباتـهـ والتنسيق فيما بين وحداته.

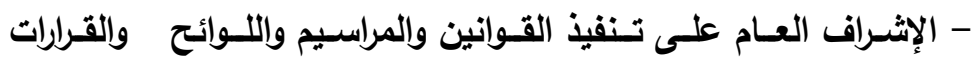

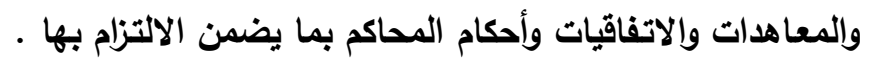

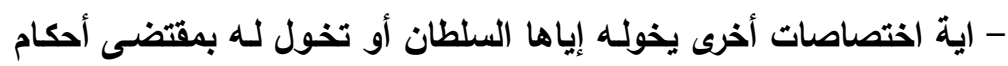
القانون.

مـادة (0 ؛): يتـولى رئيس مجلس الـوزراء رئاسـة جلسـات المجلس ولـهـ إسـناد إدارة

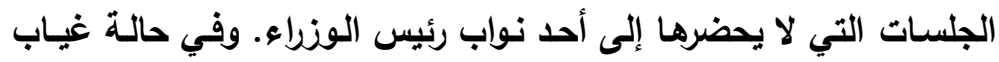

رئيس الوزراء ونوابـه يفوض السلطان من يراه مناسبا لإدارة الجلسات.

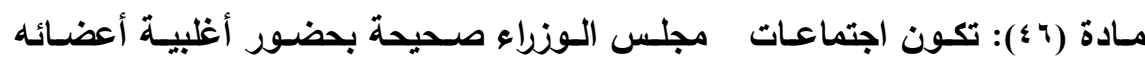
ومداولاته سرية، وتصدر قراراته بموافقة أغلبية الحاضرين.

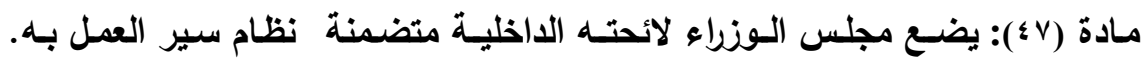

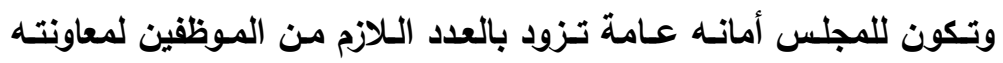

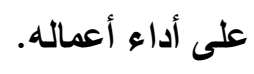

رئيس مجلس الوزراء ونوابه والوزراء 
و

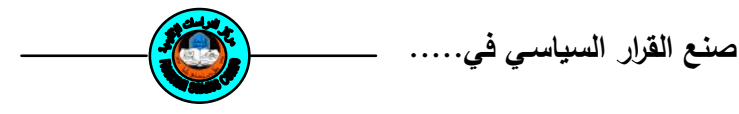

مادة (^^): إذا عين السلطان رئيسـا لمجلس الوزراء حددت اختصاصاته وصلاحياته

$$
\text { بمقتضى مرسوم تعيينه. }
$$

مادة (9 ؛) يشترط فيمن يعين رئيسا لمجلس الوزراء أو نائبا لـه أو وزيرا مايلي :

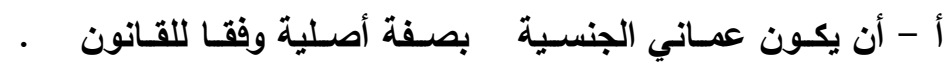

$$
\text { ب - ألا تقل سنه عن ثلاثين سنة ميلادية . }
$$

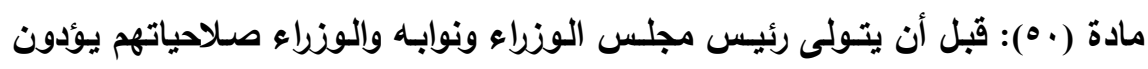
أمام السلطان اليمين التالية:

(أقسم باللّه العظيم أن أكون مخلصا لسلطاني ويلادي، وأن أحترم النظام

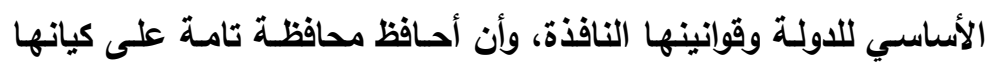

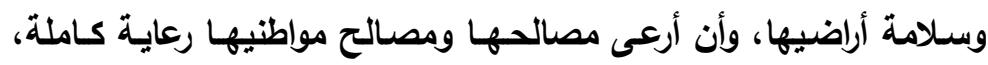
وأن أودي واجباتي بالصدق والأمانة).

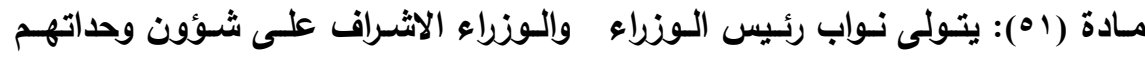

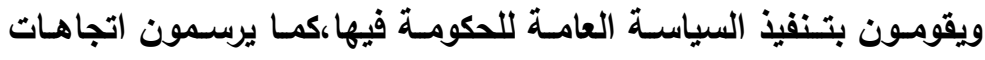

الوحدة ويتابعون تنفيذها.

مـادة (ro): أعضــاء مجلس الـوزراء مسؤولون سـياسيا مسؤولية تضـامنية أمسام السلطان عن تنفيذ السياسة العامـة للاولـة. وكل منهم مسؤول مسؤولية

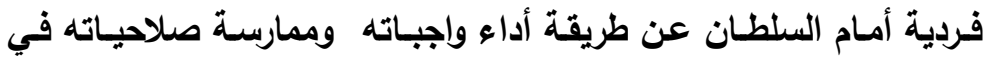

$$
\text { وزارته أو وحد ته. }
$$

مـادة (ro): لا يجـوز لأعضـاء مجلس و الـوزلهاء أن يجمعوا بين مناصبهم الـوزارية

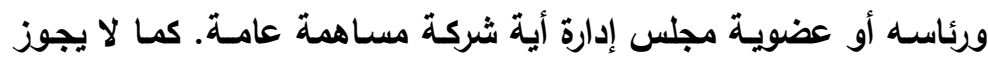

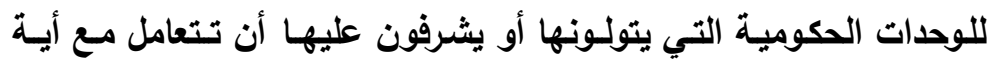

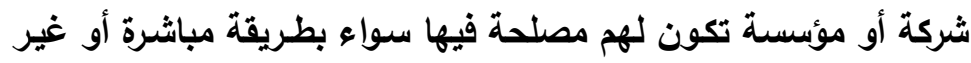

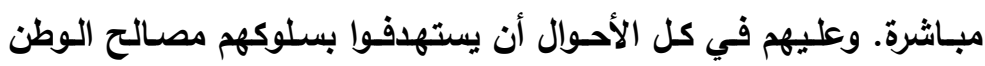


د (

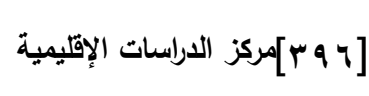

واعلاء كلمة الصالح العام وألا يستظلوا مراكزهم الرسمية بأيه صـورة كانت

لفائدتهم أو لفائدة من تصلهم به علاقة خاصة.

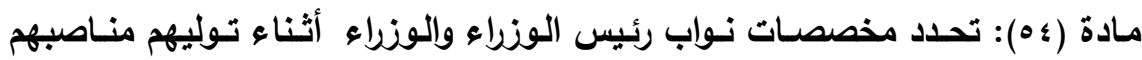

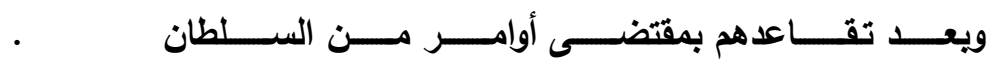

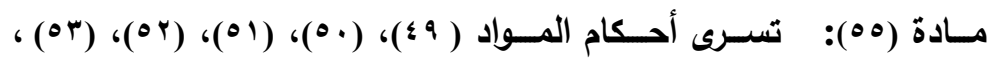

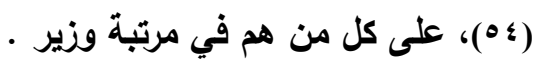

المجالس المتخصصة

مادة (זه): تنشأ المجالس المتخصصـة وتحدد صلاحياتها ويعين أعضاؤها بمقتضى المئه مراسيم سلطانية.

\section{الشؤون المالية}

مادة (ه) : يبين القانون الأحكام الخاصة بالمسائل التالية والجهات المسؤولة عنها. - تحصيل الضرائب والرسوم وغيرها من الأموال العامة وإجراءات صرفها. - حفظ أملاك الدولة وإدارتها وشروط التصرف فيهالب وئها، والحدود الاهول التي يجوز فيها التنازل عن شعى من هذه الأملاك.

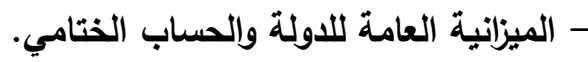
- الميزانيات العامة المستقلة والملحقة وحساباتها الختامية. - الرقابة المالية للاولة. - القروض التي تقدمها أو تحصل عليها الدولة. - النقد والمصارف، والمقاييس والمكاييل والموازين.

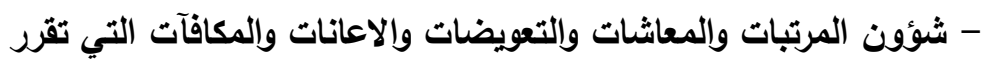
على خزانة الدولة.

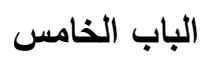




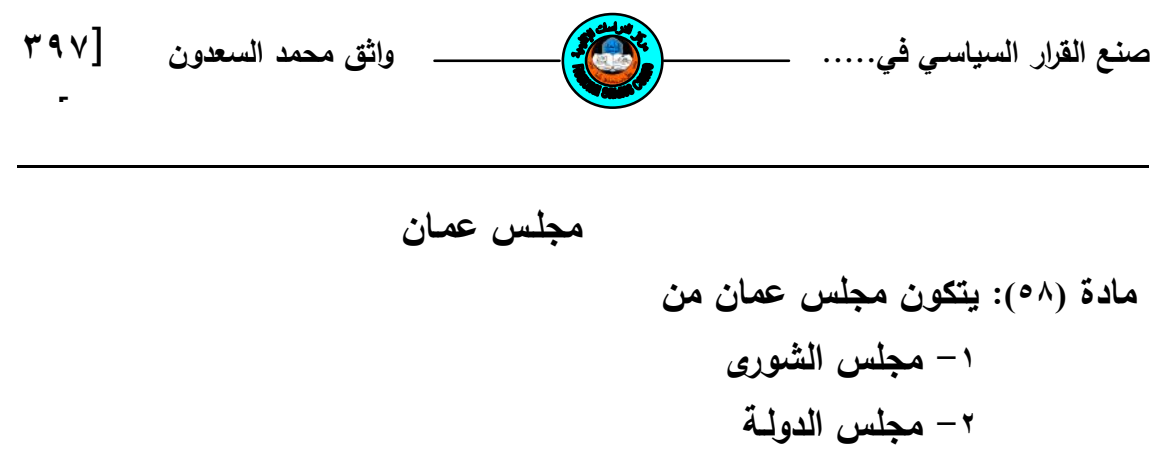

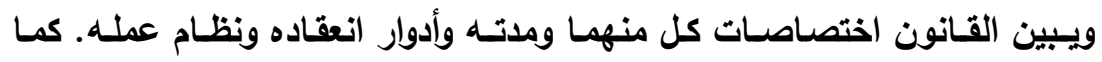

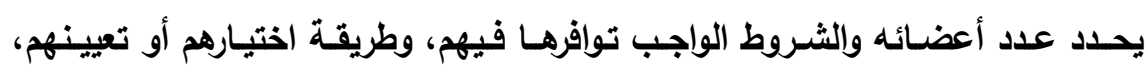
وموجبات اعفائهم، وغير ذلك من الأحكام التنظيمية

$$
\text { الباب السادس }
$$

مادة (9ه): سيادة القانون أساس الحكم في الدولة. وشرف القضاء ونزاهة القضاة وعدلهم ضمان للحقوق والحريات.

مـادة (·)): السلطة القضائية مستقلة، وتتولاها المحاكم على اختلاف أنواعها ودرجاتها، وتصدر أحكامها وفق القانون.

مادة (1"): لا سلطان على القضاة في قضائهم لغير القانون. وهم غير قابلين للعزل

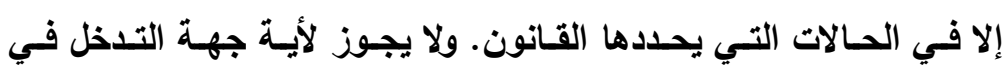

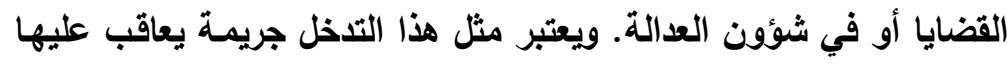

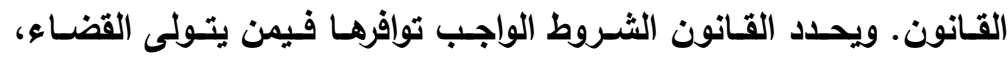
وشروط وإجراءات تعيين القضاة ونقلهم وترقيتهم والضمانات المقررة لهم

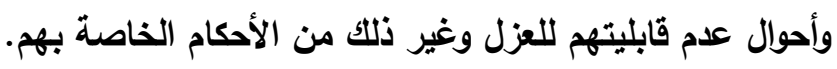

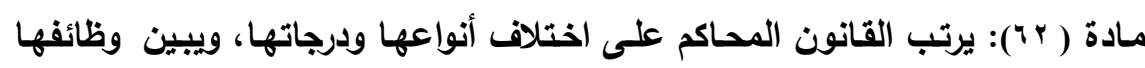
واختصاصاتها، ويقتصر اختصاص المحاكم العكرية على الجرائم العكرية 
التي تقع من أفراد القوات المسلحة وقوات الأمن ولايمتد الى غيرهم إلا في حالة الحكم العرفي وذلك في الحدود التي يقرهـا القانون.

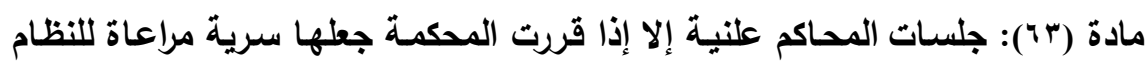

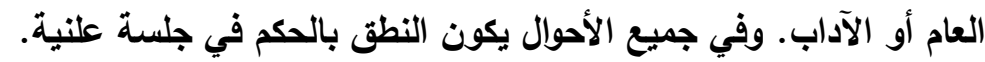

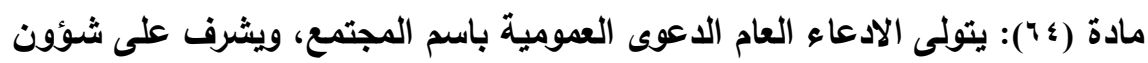

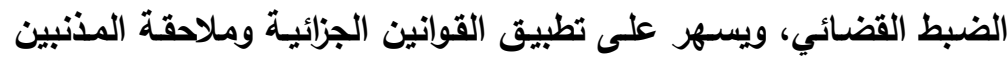

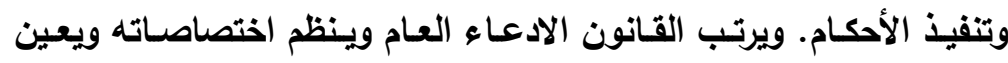

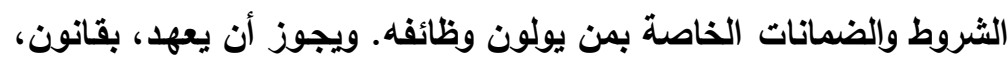

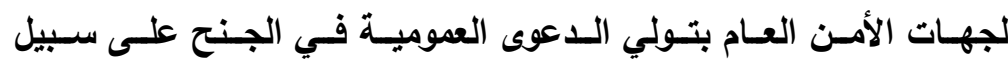
الاستثناء، ووفقا للأوضاع التي يبينها القانون. مادة (70): ينظم القانون مهنة المحاماة. مادة (74): يكون للقضاء مجلس أعلى يشرف على حسن سبر العمل في المحاكم

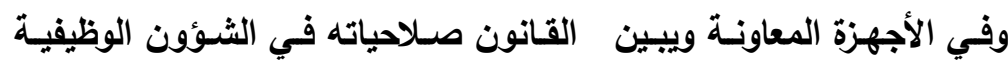
للقضاة والادعاء العام.

مـادة (vi): ينظم القانون الفصل في الخصومات الإداريـة بواسطة دائرة أو محكمـة خاصة يبين القانون نظامها وكيفية ممارستها للقضاء الإداري.

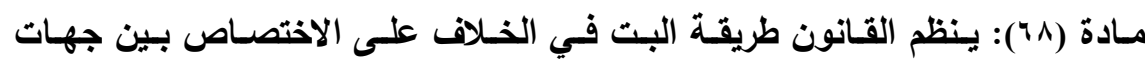
القضاء وفي تنازع الأحكام.

مادة (99): يحدد القانون اختصاصات الجهة التي تتولى إبداء الرأي القانونسي للوزارات والجهات الحكوميـة الأخرى، وتقوم بصياغة مشـروعات القوانين واللـوائح

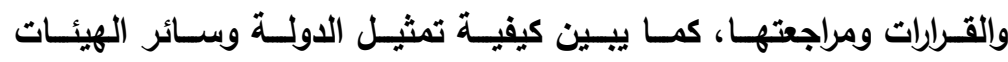
والمؤسسات العامة أمام جهات القضاء . 
مسادة ( • V) يعين القـانون الجهـة القضـائية التـي تختص بالفصـل في المنازعـات المتعلقة بمدى تطابق القوانين واللوائح مـع النظام الأساسي للاولـة وعدم لـام

مخالقتها لأحكامه، ويبين صلاحياتها والاجراءات التي تتبعها.

مادة (V) : V ) تصدر الأحكام وتنفذ باسم جلالة السلطان. ويكون الامتـاع عن تنفيذها

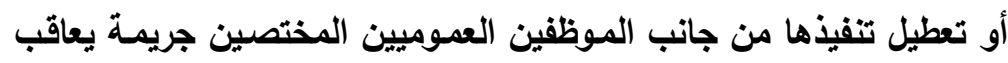
عليها القانون. وللمحكوم لـه في هذه الحالـة حق رفئ الدعوى الجنائيـة مباثرة الى المحكمة المختصة.

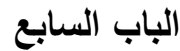

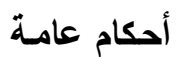

مادة (VY) : يخل تطبيق هذا النظام بما ارتبطت به سلطنة عمان مع الدول والهيئات والمنظمات الدولية من معاهدات واتفاقيات.

مادة (Vr): لايجوز تعطيل أي حكم من أحكام هذا النظام إلا أثناء قيام الأحكام العرفية وفي الحدود التي يبينها القانون

مـادة (Y): تنشر القوانين في الجريدة الرسمية خـلال أسبوعين مـن يوم إصدارها،

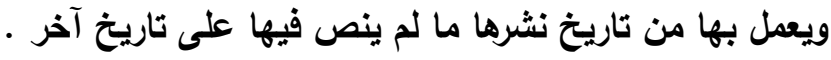

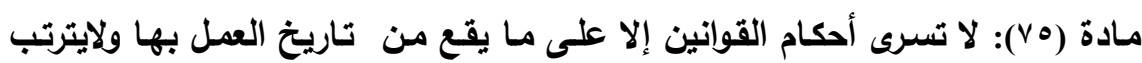

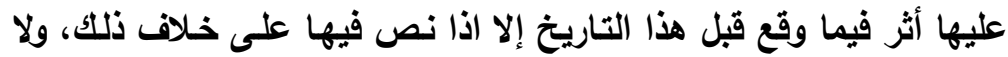
يشمل هذا الاستثناء القوانين الجزائية وقوانين الضرائب والرسوم المالية.

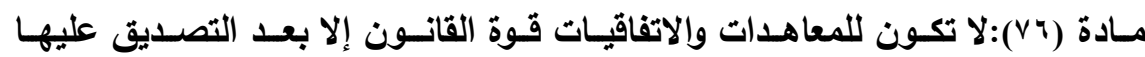
ولايجوز في أي حال أن تتضمن المعاهدة أو الاتفاقية شروطا سرية تناقض الآن شروطها العلنية. مـادة (VV): كل مـا قرتها لقوانين واللوائح والمراسيم والأوامر والقرارات المعمول بها

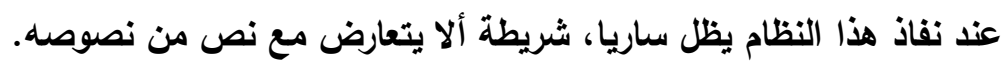


مـادة (V^): تعـل الجهات المختصـة علـى استصــار القـوانين غيـر القائمــة والتـي يستلزمها هذا النظام وذلك خلال سنتين من تاريخ العمل به.

مـادة (V9): يجب أن تتطابق القوانين والإجراءات التي لها قوة القانون مـع أحكام

$$
\text { النظام الأساسي للاولة. }
$$

مادة (•^): لا يجوز لأية جهة في الدولة إصدار أنظمة أو لوائح أو قرارات أو تعليمات تخالف أحكام القوانين والمراسيم النافذة أو المعاهدات والاتفاقيـات الدولية الداتية

$$
\text { التي هي جزء من قانون البلاد . التحان }
$$

مادة (^)): لا يجرى تعديل هذا النظام إلا بنفس الطريقة التي تم بها إصداره

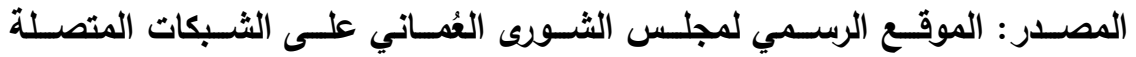

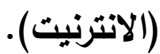

\title{
Decision Making in the Sultanate of Oman
}

\section{By: Mr Wathig Mohamoned Bassak Al - Saadoun Mosul University.Regional Studies Center}

\begin{abstract}
The ruling system in Oman transferred، as the case in all Arab Gulf States، from the traditional and tribal from of alliance into a rule of a royal family. But ' Oman was distinguished by the rule of AL- Ebadhiya AL- Immamiah which is dominated this state during some period of its history. However this Sultanate witnesses currently existence of political circles whether executive or legislative as the council of ministers and the council of Oman (Parliament); but t the actual center for decision making is the Sultan and the close circle to him. However' there are continuous
\end{abstract}


efforts for reforming and enlarging the base of participation; the track of these efforts is controlled by internal and external impacts that affect decision making in this country.

\section{الهوامش والمصادر}

(1) محمود شاكر، موسوعة تاريخ الخليج العربي، جا، طه، دار أسامة للنشر والتوزيع، (عمان، (1)

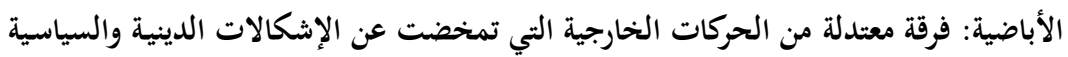

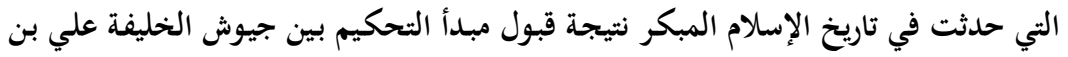

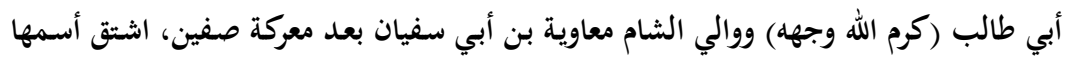

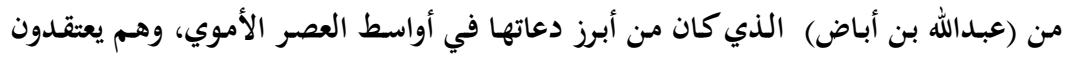

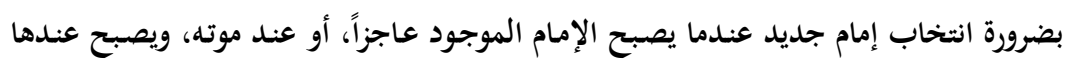

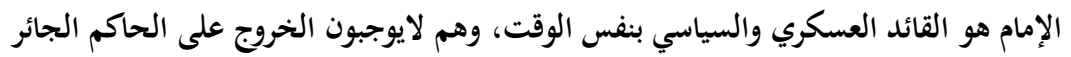

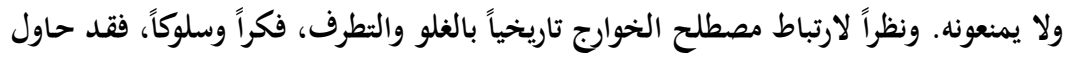

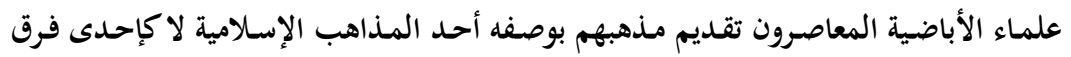

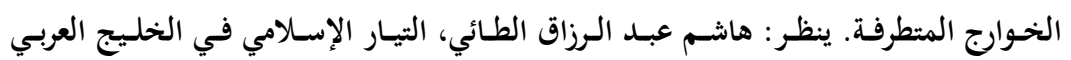

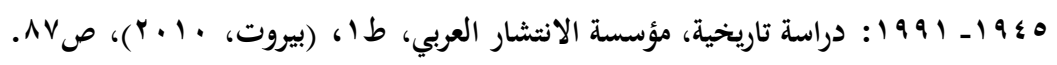

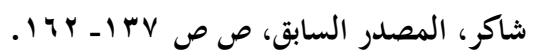

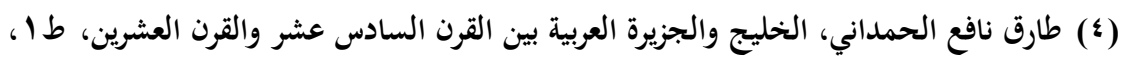

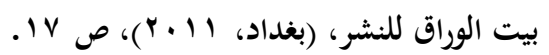

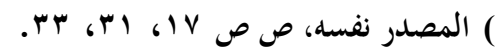

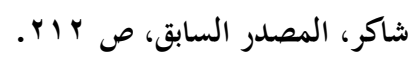

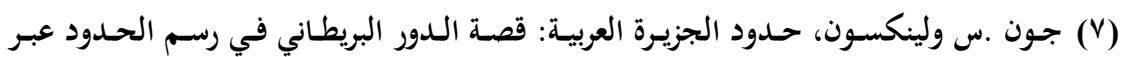

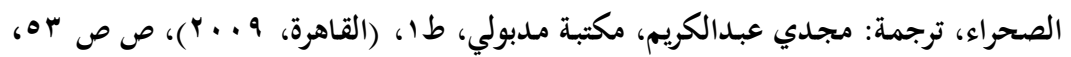

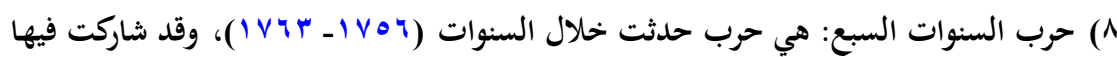

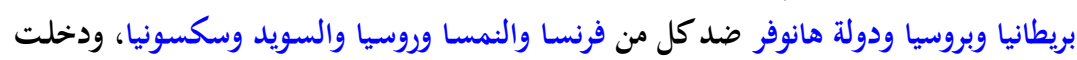

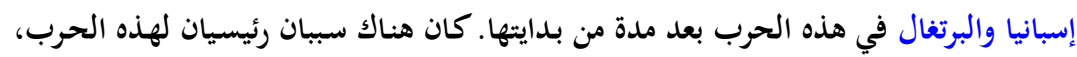




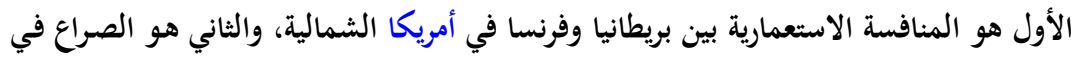

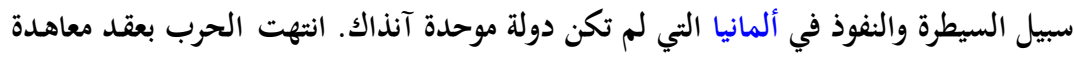

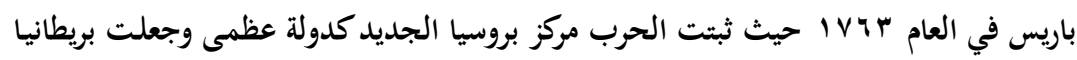

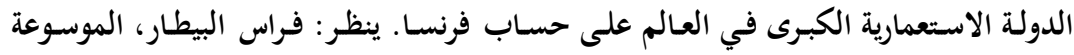

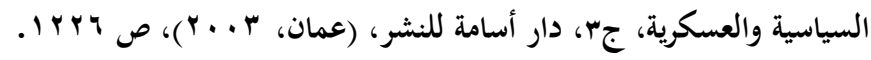

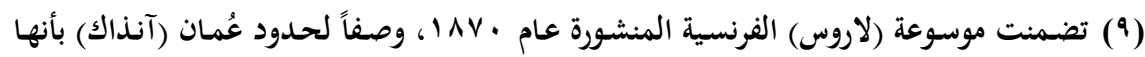

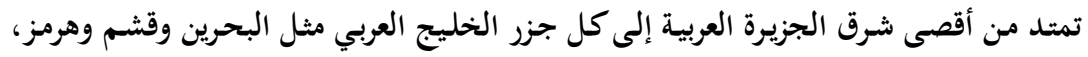

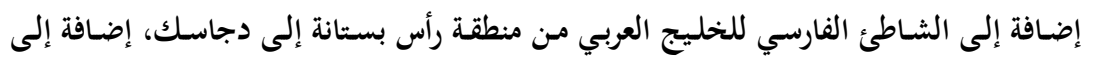

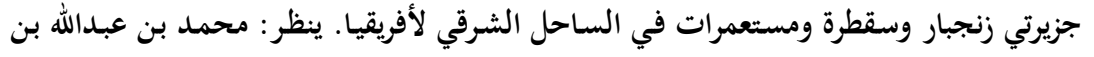

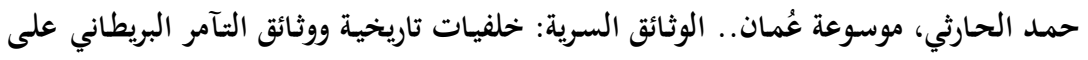

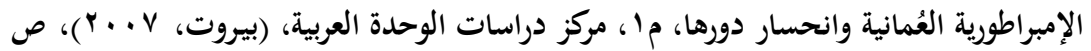

(· (1) ناهد عبدالكريم، "تأسيس الدولة الحديثة في سلطنة عُمان"، بحث غير منشور من أرشيف كلية

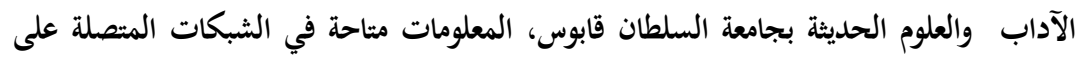

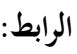

-http://www.attarikh-alarabi.ma/Html/adaa36partie2.htm

للمزيد من المعلومات عن العلاقات البريطانية- العُمانية في هذه الفترة ينظر: الحارثي، البراتي

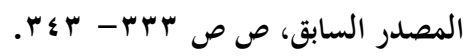

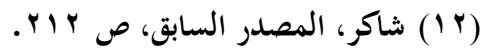

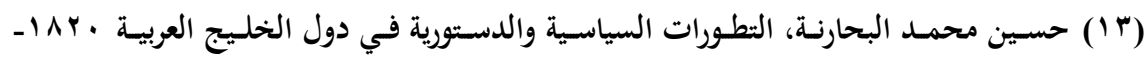

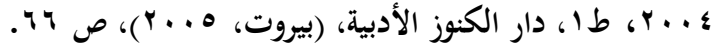

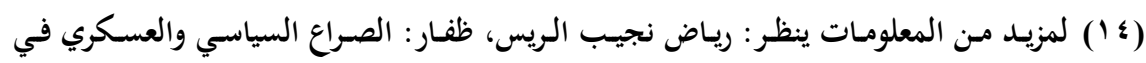

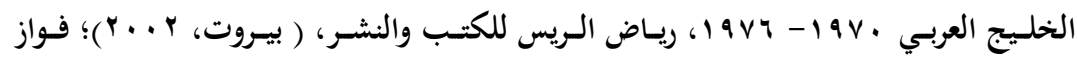

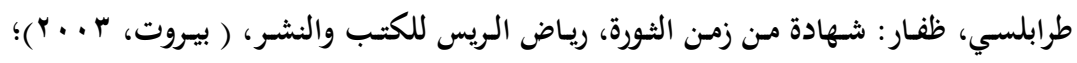

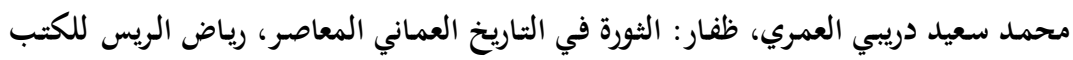

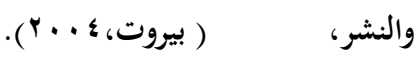

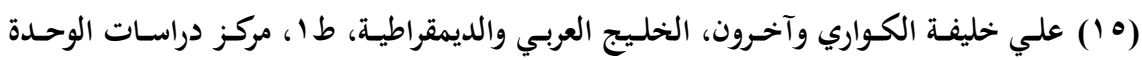

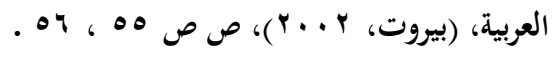




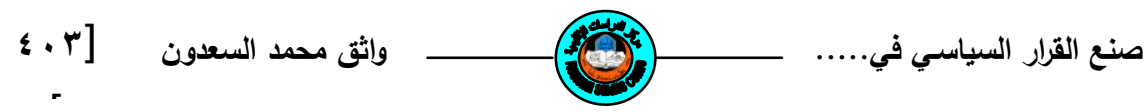

(1 (1) حسين محمد البحارنة، دول الخليج العربي الحديثة، علاقاتها الدولية وتطور الأوضاع السياسية

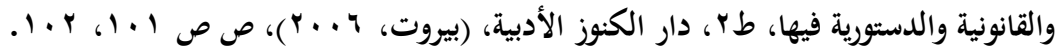

Brian Porter، Book review "The Sultanate of Oman: A Twentieth-Century History. by Miriam Joyce"، International Affairs Journal، Vol. 73، No. 2، Cambridge University Press، (London‘ 1997)‘ pp. 380‘381.

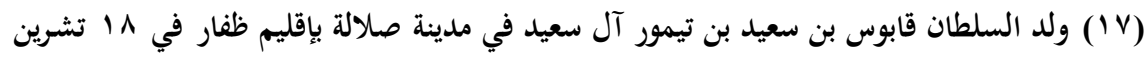

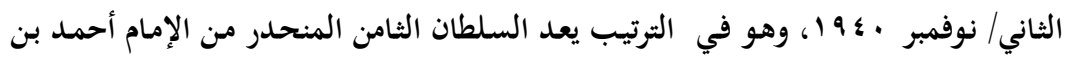

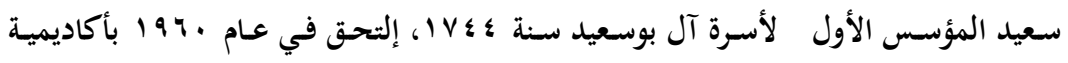

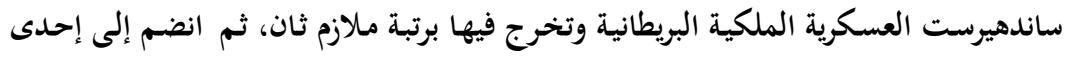

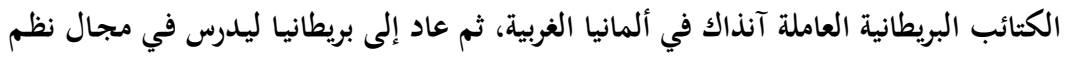

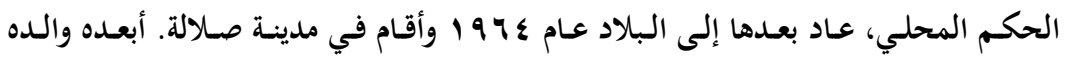

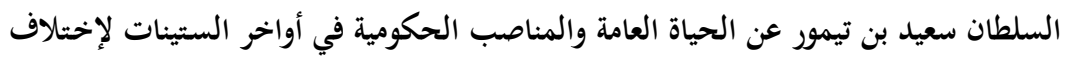

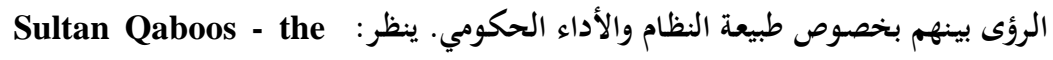

Human Being

<http://www.oman.om/oman-qaboos/index.htm>

$$
\begin{aligned}
& \text { البحارنة، دول الخليج العربي الحديثة، المصدر السابق، ص \& ـ ـ أ. }
\end{aligned}
$$

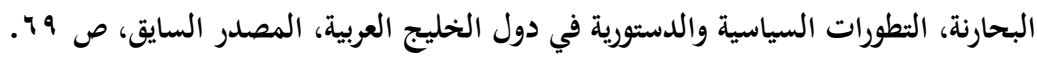

(20) Joseph A. Kechichian، "A Vision of Oman: State of the Sultanate speeches by Qaboos Bin Said، 1970- 2006"، Middle East Policy Journal، Vol. XV، No. 3، Blackwell، (USA، 2008)، p.130.

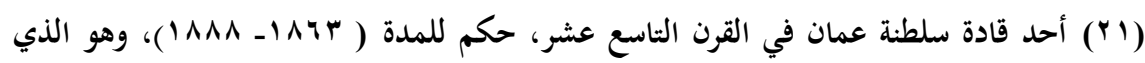

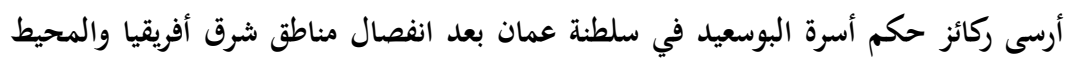

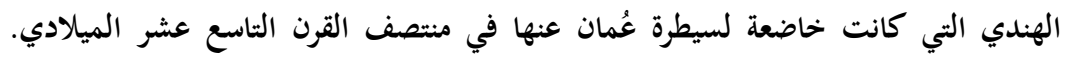

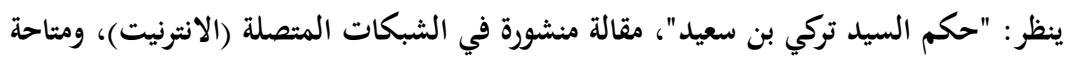
-http://www.majalisna.com/oman/articles.php?option=read\&AID=25

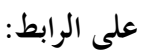

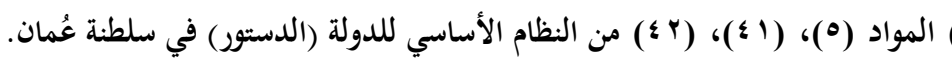

(23) Kechichian، Op.Cit.‘p.p 112- 132. 


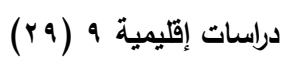
[ ] ـ ع [مكز الدراسات الإقليمية

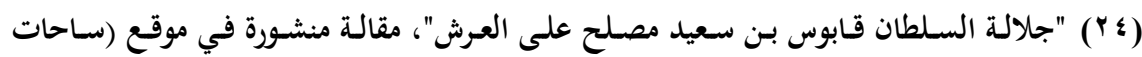

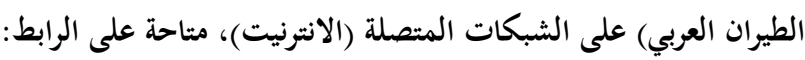

-http://4flying.com/showthread.php?t=34467

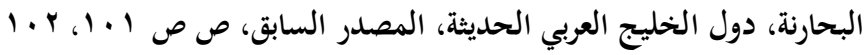

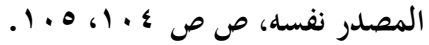

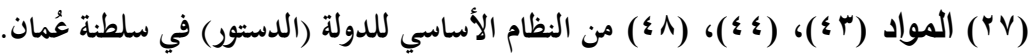

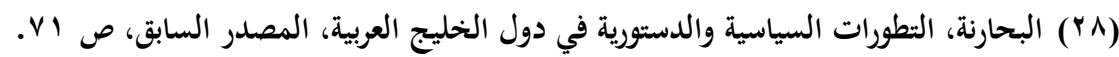

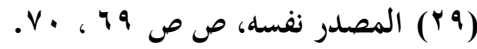

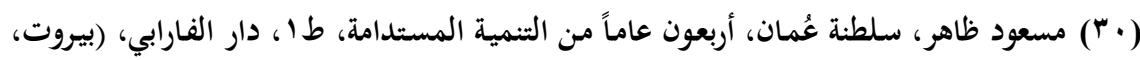
(r)

(اسب) البحارنة، النطورات السياسية والدستورية في دول الخليج العربيـة، المصـدر السـابق، ص ص • V،

(Yץ) زيـاد عبـدالوهاب النعيمي، ((آليـة صـنع القـرار السياسي في ظل المتغيـرات الدوليـة))، مقالة

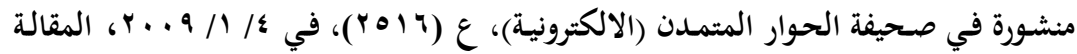

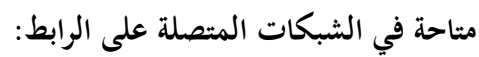

-www.ahewar.org/debat/show.art.asp?aid=158450

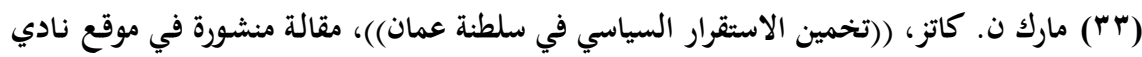

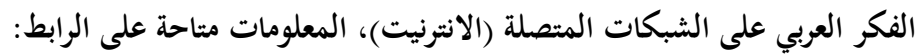

-http://www.s-oman.net/avb/showthread.php?t=110538

$$
\begin{aligned}
& \text { ( } \\
& \text { (ro) } \\
& \text { ( ) ( }
\end{aligned}
$$

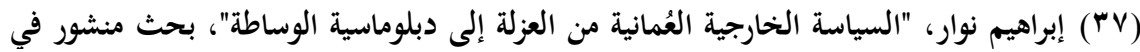

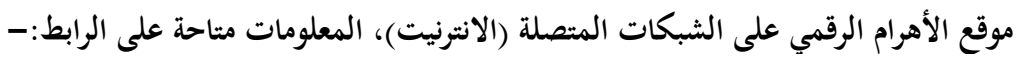

http://digital.ahram.org.eg/articles.aspx?Serial=217392\&eid=13

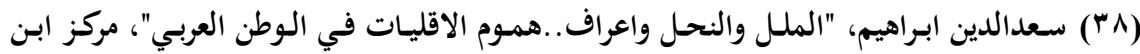

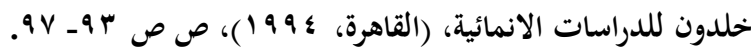

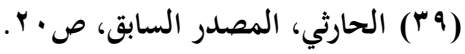


(40) Kechichian، Op.Cit.، p.p. 121- 122.

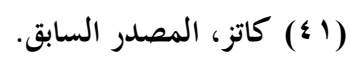

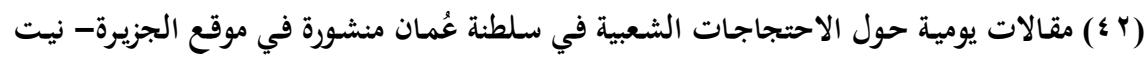

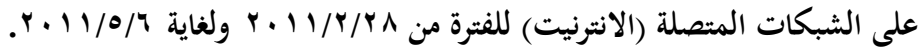

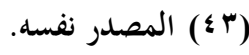

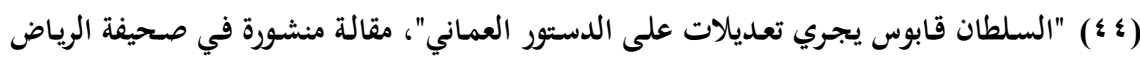

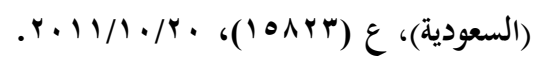

(0؛) مارينا أوتاوي، "دعم الديمقراطية في الشرق الأوسط: إستعادة المصداقية"، سلسلة (شرح

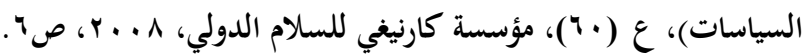

$$
\begin{aligned}
& \text { (־ ) كاتز، المصدر السابق. }
\end{aligned}
$$

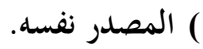

(48) Kechichian، Op.Cit.، p. 120.

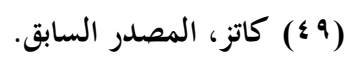

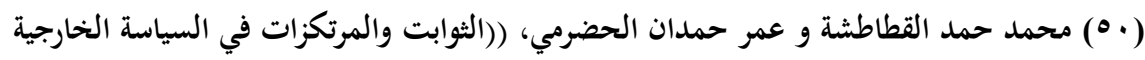

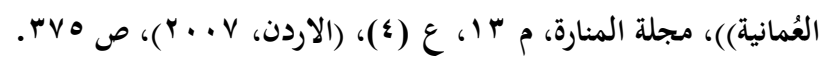

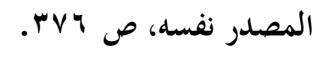

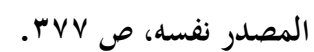

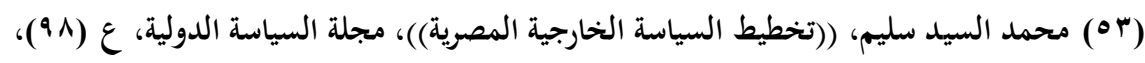

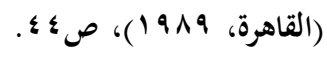

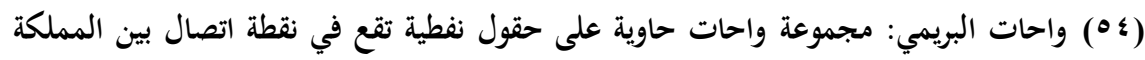

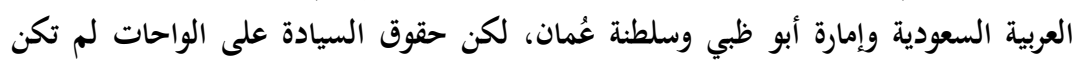

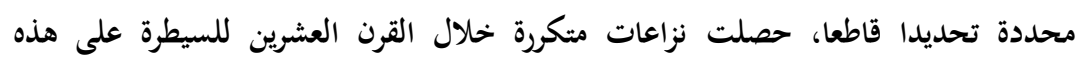

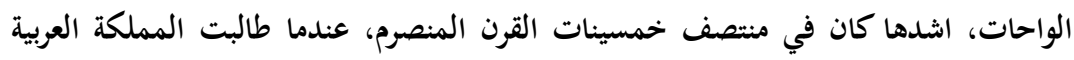

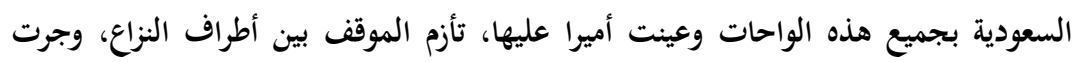

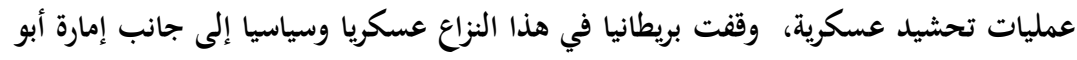

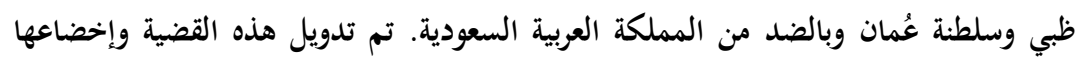

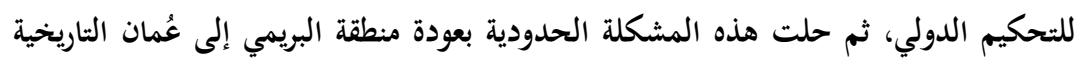

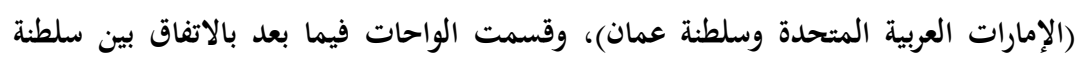


عُمان، وإمارة أبوظبي، وتم منح السعودية الأراضي المتاخمة للحدود القطرية من أراضي

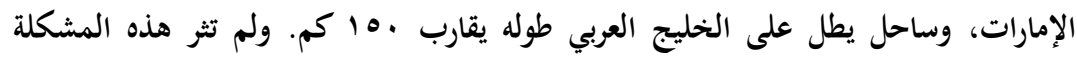

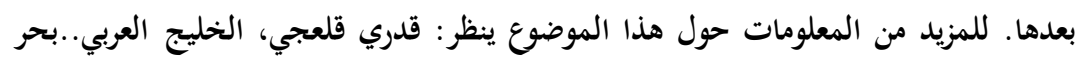

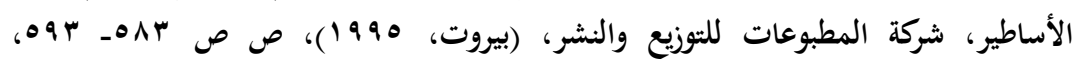

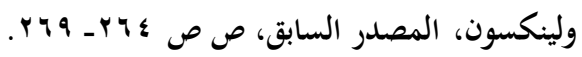

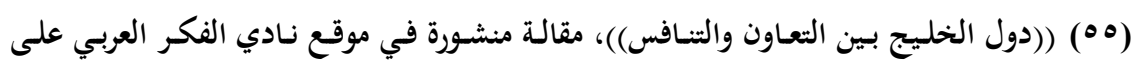

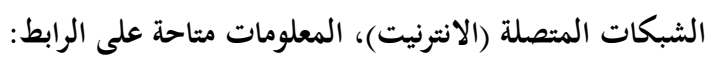

- http://nadyelfikr.com/showthread.php?tid=41495

(57) Willem H. Buiter،" Economic‘ Political، and Institutional Prerequisites for Monetary Union Among the Members of the Gulf Cooperation Counci "، Open economies review Journal، Volume. 19، Issue. 5، Springer، (London‘2008) p.611.

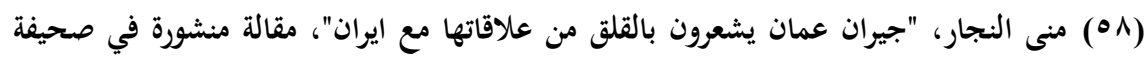

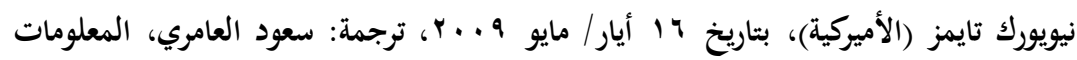

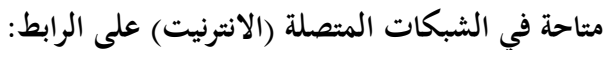
-http://omanh.blogspot.com/2010/01/blog-post.

(59) Joseph A. Kechichian، Oman and the World: The Emergence of an Independent Foreign Policy، (Santa Monica University، 1995)، pp.99100.

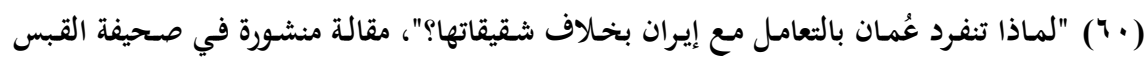

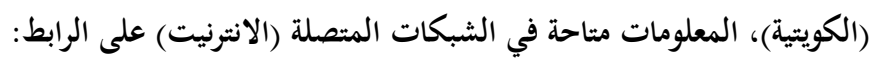

-http://www.alqabas.com.kw/Article.as...\&date=26092010

$$
\begin{aligned}
& \text { (1) } \\
& \text { (זיד) النجار، المصدر السابق. } \\
& \text { (ז'آ) المصدر نفسه. } \\
& \text { (؟ (7) المصدر نفسه. }
\end{aligned}
$$




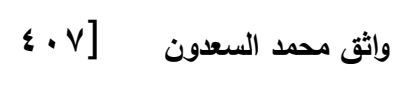

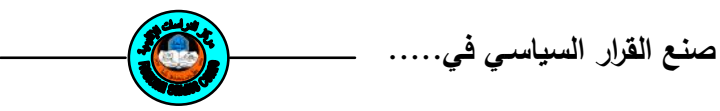

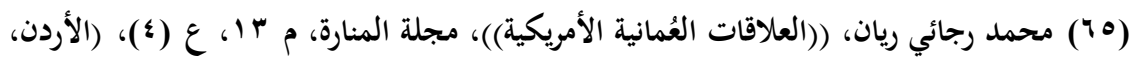

$$
\text { r r T }
$$

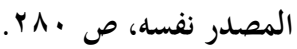

(67) New York Times، 6 June 1980.

(†^) سهيلة عبد الأنيس، ((أبعاد الوجود العسكري الأميركي في الخليج والاتفاقية الأمنية العراقية

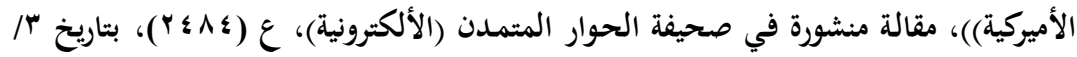

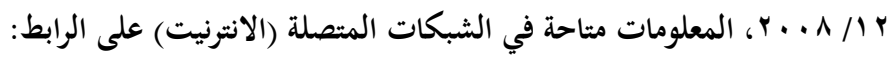

-http://www.ahewar.org/debat/show.art.asp?aid=155187

(997) أوتاوي، المصدر السابق، ص؛. 